\title{
Nucleic acid amplification strategies facilitating the detection of genetically modified crop ingredients in foods
}

\author{
By \\ Johanna Leggate, B.Sc. (Biochemistry \& Biotechnology)
}

A thesis submitted to the Faculty of Graduate Studies in partial fulfillment of the requirements for the degree of Master of Science

\author{
College of Natural Sciences \\ Department of Biology \\ Carleton University \\ Ottawa, Ontario
}

September 14, 2006

(C) Leggate, 2006 


$\begin{array}{ll}\begin{array}{l}\text { Library and } \\ \text { Archives Canada }\end{array} & \begin{array}{l}\text { Bibliothèque et } \\ \text { Archives Canada }\end{array} \\ \begin{array}{l}\text { Published Heritage } \\ \text { Branch }\end{array} & \begin{array}{l}\text { Direction du } \\ \text { Patrimoine de l'édition }\end{array} \\ \begin{array}{l}\text { 395 Wellington Street } \\ \text { Ottawa ON K1A 0N4 }\end{array} & \begin{array}{l}\text { 395, rue Wellington } \\ \text { Ottana ON K1A ON4 } \\ \text { Canada Oa }\end{array}\end{array}$

Your file Votre référence ISBN: 978-0-494-18368-7 Our file Notre référence ISBN: $978-0-494-18368-7$

NOTICE:

The author has granted a nonexclusive license allowing Library and Archives Canada to reproduce, publish, archive, preserve, conserve, communicate to the public by telecommunication or on the Internet, loan, distribute and sell theses worldwide, for commercial or noncommercial purposes, in microform, paper, electronic and/or any other formats.

The author retains copyright ownership and moral rights in this thesis. Neither the thesis nor substantial extracts from it may be printed or otherwise reproduced without the author's permission.
AVIS:

L'auteur a accordé une licence non exclusive permettant à la Bibliothèque et Archives Canada de reproduire, publier, archiver, sauvegarder, conserver, transmettre au public par télécommunication ou par l'Internet, prêter, distribuer et vendre des thèses partout dans le monde, à des fins commerciales ou autres, sur support microforme, papier, électronique et/ou autres formats.

L'auteur conserve la propriété du droit d'auteur et des droits moraux qui protège cette thèse. $\mathrm{Ni}$ la thèse ni des extraits substantiels de celle-ci ne doivent être imprimés ou autrement reproduits sans son autorisation.
In compliance with the Canadian

Privacy Act some supporting forms may have been removed from this thesis.

While these forms may be included in the document page count, their removal does not represent any loss of content from the thesis.
Conformément à la loi canadienne sur la protection de la vie privée, quelques formulaires secondaires ont été enlevés de cette thèse.

Bien que ces formulaires aient inclus dans la pagination, il n'y aura aucun contenu manquant. 


\begin{abstract}
The detection of genetically modified crop ingredients in foods using molecular techniques poses several challenges with regards to the identification of all possible target analytes present, sample matrix effects and the assessment of sample quality. Foods can contain many different genetically modified crop ingredients; each of which must be identified as part of a comprehensive analysis. A cloth-based hybridization array system (CHAS) was developed for the identification of crops by a multiplex PCR targeting specific genes in corn, soy, rice, wheat, and potato, representative of common food crops for which genetically modified versions have been approved for cultivation or import into Canada.
\end{abstract}

The amplification of DNA extracted from foods can be affected by the presence of PCR inhibitors. As an indicator of PCR amplification efficiency, a simple templateindependent internal amplification control (IAC) system was developed as a quality control element for the assay.

The successful operation of nucleic acid amplification techniques such as PCR requires knowledge of the quantity of DNA present in the sample extracts. A simple, high-throughput, microplate fluorescence assay (MFA) was developed using the doublestranded DNA-binding dye SYBR Green I. 


\section{ACKNOWLEDGEMENTS}

I would like to extend my sincere gratitude to my thesis supervisor, Dr. Burton W. Blais, for giving me the opportunity to work on a project that has proven to be a truly enjoyable experience, and for his excellent guidance through the course of this work. I would also like to express my gratitude to Dr. Linda Bonen, Dr. Iain Lambert and Dr. Bill Willmore, for taking the time from their demanding schedules to serve on my committee, and for providing me with such valuable feedback and advice. Additionally, I would like to thank Dr. Delano James, Centre for Plant Health, CFIA, for advice on the selection of probe sequences, and Leah Isaac and Ray Allain, whose help and technical expertise relating to DNA quantification, molecular analysis and GMO testing was very much appreciated. I also would like to say thank you to Amalia Martinez-Perez for her assistance, advice and most insightful discussions. Finally, I would like to thank my parents, Bill \& Lise Leggate and Catherine \& Dennis Desjardins, and my partner, Mark Murphy, for their patience, continuous encouragement and support throughout this endeavour. This project was funded by the CFIA Canadian Regulatory System for Biotechnology (CRSB) initiative. 


\section{TABLE OF CONTENTS}

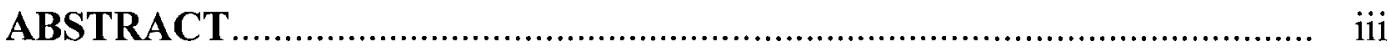

ACKNOWLEDGEMENTS.............................................................. iv

TABLE OF CONTENTS ............................................................ $\mathrm{v}$

LIST OF TABLES....................................................................... vii

LIST OF FIGURES ......................................................................... viii

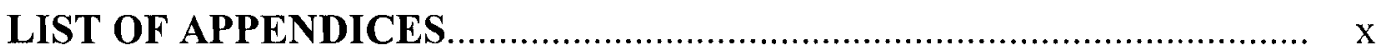

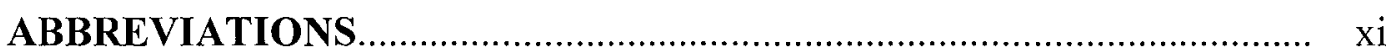

Chapter 1. General Introduction............................................................. 2

Detection strategies for genetically modified organisms in foods.................. 7

Strategies for the analysis of PCR-amplified DNA ........................................ 12

Protein-based detection methods.................................................................. 17

Thesis objectives................................................................................ 19

Chapter 2. Microplate fluorescence assay for the quantification of double stranded DNA using SYBR Green I dye....

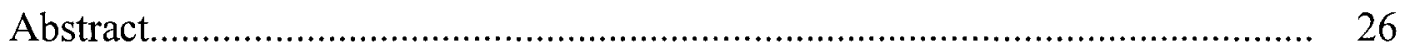

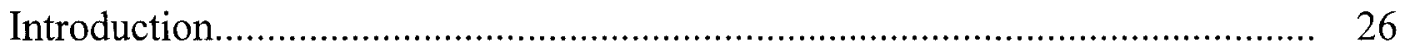

Materials and Methods......................................................................... 29

Results and Discussion......................................................................... 31

Performance characteristics................................................................ 31

Quantification of PCR product............................................................ 37

Effect of contaminants on DNA quantification........................................ 39

Chapter 3. An internal amplification control system based on primer-dimer formation for PCR product detection by DNA hybridization.

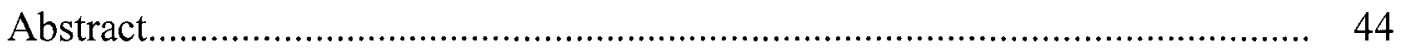

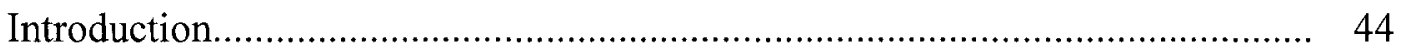

Materials and Methods............................................................................ 48

Results and Discussion.......................................................................... 52

Effect of IAC on target gene amplification by PCR ................................. 55

Effect of PCR conditions on the IAC ...................................................... 57

Effect of sample condition on the IAC .................................................. 60

Application of the IAC in a multiplex PCR-CHAS format....................... 62 
Chapter 4. Cloth-based hybridization array system for detection of multiple plant crops by multiplex polymerase chain reaction.

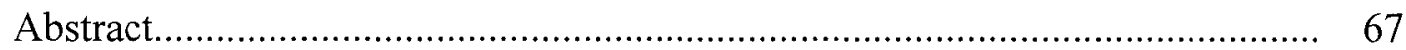

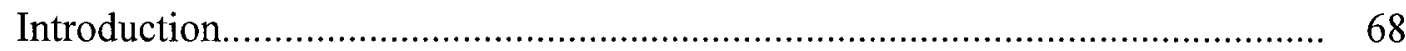

Materials and Methods...................................................................... 72

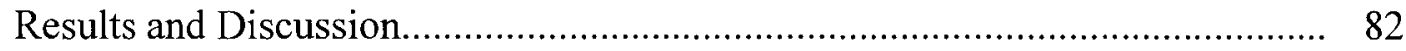

Limit of detection................................................................................... 82

Analysis of flour blends..................................................................... 84

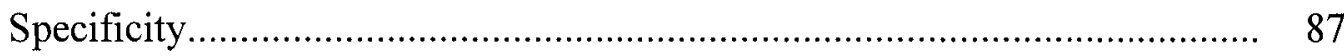

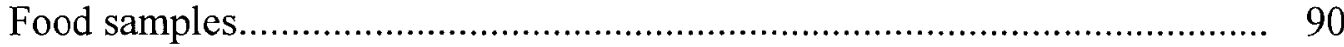

Chapter 5. General Conclusions.............................................................. 96

Appendix A. Development of an ultrasensitive immunoassay for the detection of trace amounts of protein in highly processed food samples.

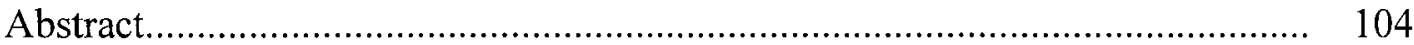

Introduction..................................................................................... 104

Materials and Methods........................................................................... 109

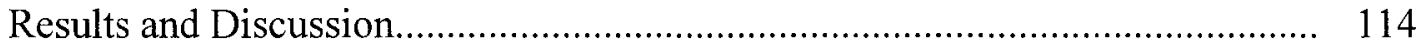

Optimization of transcription conditions................................................. 114

Development of the ImmunoScript assay............................................ 120

Development of Immuno-NASBA........................................................ 122

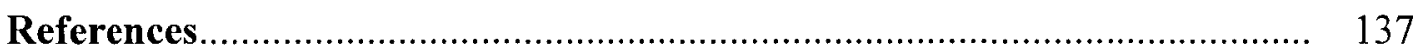




\section{LIST OF TABLES}

Table 1.1 Polymerase chain reaction (PCR) based systems for the detection of genetically modified organisms (GMOs) in foods

Table 3.1 Oligonucleotide primer and probe sequences for PCR-DNA hybridization procedure.

Table 3.2 Effect of IAC primers on detectability of the soy lectin PCRcloth hybridization procedure.

Table 3.3 Effect of annealing temperature on the soy lectin PCR-cloth hybridization procedure.

Table 3.4 Effect of magnesium chloride on the soy lectin PCR-cloth hybridization procedure

Table 3.5 Effect of inhibitors on the soy lectin PCR-cloth hybridization procedure

Table 4.1 Ingredients for food samples purchased from a local supermarket for subsequent analysis by the combined multiplex-PCR Crop CHAS procedure

Table 4.2 Oligonucleotide primer and probe sequences for PCR-DNA hybridization procedure

Table 4.3 Detectability of multiplex PCR-CHAS in the assay of different amounts genomic DNA from each of the target crops

Table 4.4 Detectability of multiplex PCR-CHAS in the assay of corn and soy flours.

Table 4.5 Specificity of multiplex PCR-CHAS in the assay of various phylogenetically similar crops.

Table 4.6 Detectability of multiplex PCR-CHAS in the assay of extracted DNA from processed foods. 


\section{LIST OF FIGURES}

Figure 1.1 Simplified representation of a typical transgenic insert (gene construct)

Figure 1.2 Schematic representation of the Cloth-based Hybridization Array System (CHAS)

Figure 2.1 Comparison of the performance characteristics of the three DNA quantification methods using calf thymus DNA

Figure 2.2 Comparison of the performance characteristics of the three DNA quantification methods using bacteriophage Lambda DNA...........

Figure 2.3 Dose response characteristics of the MFA over a broad range of calf thymus DNA concentrations.

Figure 2.4 Comparison of the performance characteristics of the three DNA quantification methods using a two-fold dilution series of purified PCR product.

Figure 2.5 Effect of contaminants on DNA quantification. 40

Figure 3.1 Schematic representation of the internal amplification control (IAC) concept.

Figure 3.2 Detection of PCR products by soy lectin PCR-cloth hybridization and agarose gel electrophoresis.

Figure 3.3 Detection of transgenic corn and soy in a Multiplex PCR-CHAS incorporating the IAC sequences.

Figure 4.1 Schematic representation of the combined multiplex PCR and CHAS for the determination of crop ingredients in foods.

Figure A.1 Schematic representation of the ImmunoScript assay 108

Figure A.2 Comparison of fluorescence intensities obtained by subjecting different amounts of purified 216-bp (T7-35S-1,2) or 218-bp (SP6-35S-1,2) transcriptionally active PCR amplicon to an in vitro transcription reaction. 
Figure A.3 Comparison of fluorescence intensities obtained by subjecting 10 ng of purified 216-bp (T7-35S-1,2) or 218-bp (SP6-35S-1,2) transcriptionally active $\mathrm{PCR}$ amplicon to an in vitro transcription reaction using different quantities of RNA polymerase.

Figure A.4 Detection of RNA transcribed from different quantities of purified 216-bp (T7-35S-1,2) transcriptionally active PCR amplicon subjected to an in vitro transcription using optimized conditions.

Figure A.5 Comparison of the detection sensitivity of the ImmunoScript Assay to a traditional sandwich ELISA using a chicken IgY-antichicken IgY model system

Figure A.6 Schematic representation of the isothermal Nucleic Acid Sequence-Based Amplification (NASBA) reaction

Figure A.7 Detection of transcription and NASBA reaction products from different concentrations of starting template using molecular beacon probe technology

Figure A.8 Detection of transcription and NASBA reaction products from different concentrations of starting template after heating the reaction products with a $1 \mu \mathrm{M}$ solution of molecular beacon probe followed by slow cooling for $30-\mathrm{min}$.

Figure A.9 Estimated secondary structure and free energy of the RNA fragment transcribed from the $216 \mathrm{bp}$-T7 RNA promoter appended amplicon

Figure A.10 Estimated secondary structure and free energy of the RNA fragment transcribed from the $137 \mathrm{bp}-\mathrm{T} 7 \mathrm{RNA}$ promoter appended amplicon.

Figure A.11 Detection of NASBA reaction products from different concentrations of the shortened $137 \mathrm{bp}-\mathrm{T} 7 \mathrm{RNA}$ promoter appended amplicon using molecular beacon probe technology......

Figure A.12 Optimization of streptavidin concentration used to link the transcriptionally active DNA fragment to the biotinylated antichicken IgY antibody in the performance of the ImmunoNASBA assay 


\section{LIST OF APPENDICES}

Appendix A Development of an ultrasensitive immunoassay for the detection of trace amounts of protein in highly processed food samples....... 


\section{LIST OF ABBREVIATIONS}

\begin{tabular}{|c|c|}
\hline $\mathrm{A}_{260}$ & absorbance at $260 \mathrm{~nm}$ \\
\hline $\mathrm{AGE}$ & agarose gel electrophoresis \\
\hline AMV & Avian myeloblastosis virus \\
\hline bp & base pair \\
\hline $\mathrm{BSA}$ & bovine serum albumin \\
\hline${ }^{\circ} \mathrm{C}$ & degrees Celsius \\
\hline CaMV & Cauliflower Mosaic Virus \\
\hline CFIA & Canadian Food Inspection Agency \\
\hline CHAS & cloth-based hybridization array system \\
\hline $\mathrm{cm}$ & centimetre \\
\hline CRSB & Canadian Regulatory System for Biotechnology \\
\hline ctDNA & calf thymus DNA \\
\hline $\mathrm{CV}$ & coefficient of variation \\
\hline DIG & digoxigenin \\
\hline DNA & deoxyribonucleic acid \\
\hline $\mathrm{dNTP}$ & deoxyribonucleotide triphosphate \\
\hline dsDNA & double-stranded DNA \\
\hline dUTP & deoxyuridine triphosphate \\
\hline EDTA & ethylenediaminetetraacetic acid \\
\hline EIA & enzyme immunoassay \\
\hline
\end{tabular}




\begin{tabular}{|c|c|}
\hline ELISA & enzyme-linked immunosorbent assay \\
\hline EPSPS & 5-enolpyruvylshikimate-3-phosphate synthase \\
\hline GBSS & granule bound starch synthase \\
\hline GM & genetically modified \\
\hline GMO & genetically modified organism \\
\hline HSB & high salt buffer \\
\hline IAC & internal amplification control \\
\hline IDAT & Immuno-detection amplified by $\mathrm{T} 7 \mathrm{RNA}$ polymerase \\
\hline $\operatorname{Ig}$ & Immunoglobulin \\
\hline LOD & limit of detection \\
\hline LOQ & limit of quantification \\
\hline M & molar \\
\hline MFA & microplate fluorescence assay \\
\hline $\mathrm{mg}$ & milligram \\
\hline $\min$ & minute \\
\hline $\mathrm{ml}$ & millilitre \\
\hline$\mu \mathrm{g}$ & microgram \\
\hline$\mu l$ & microlitre \\
\hline$\mu \mathrm{M}$ & micro molar \\
\hline $\mathrm{mM}$ & millimolar \\
\hline $\mathrm{nm}$ & nanometre \\
\hline
\end{tabular}




\begin{tabular}{|c|c|}
\hline NASBA & nucleic acid sequence-based amplification \\
\hline NCBI & National Center for Biotechnology Information \\
\hline ng & nanogram \\
\hline NOS & nopaline synthase \\
\hline NptII & neomycin-phosphotransferase II \\
\hline NRM & NASBA reaction mixture \\
\hline PBS & phosphate buffered saline \\
\hline PBST & PBS containing Tween 20 \\
\hline PCR & polymerase chain reaction \\
\hline $\mathrm{pH}$ & potential of hydrogen \\
\hline $\mathrm{pg}$ & picogram \\
\hline POD & horseradish peroxidase \\
\hline PSS & potato sucrose synthase \\
\hline RNA & ribonucleic acid \\
\hline RPD & rice phospholipase D \\
\hline RR & RoundUp Ready \\
\hline SD & standard deviation \\
\hline SDS & sodium dodecyl sulphate \\
\hline Sltn & soy lectin \\
\hline SP6 & bacteriophage SP6 \\
\hline $\mathrm{T} 7$ & bacteriophage $\mathrm{T} 7$ \\
\hline
\end{tabular}


TDNA

TE

$\mathrm{TMB}$

Tris

TRM

U

UV

Wx transcribable DNA

Tris-EDTA

tetramethylbenzidene

hydroxymethylaminomethane

transcription reaction mixture

units

ultra violet light

wheat waxy

xiv 


\section{Chapter 1}

\section{General Introduction}


The amplification of specific DNA sequences using the polymerase chain reaction technique combined with detection by nucleic acid hybridization techniques has found many useful applications in the detection and identification of specific materials in analytical samples. In food sources there are a variety of different types of adulterants that can be present in trace amounts, including pathogenic bacteria that may cause severe foodborne illness, or undeclared ingredients that may cause a severe allergenic response in certain individuals, or otherwise be unacceptable to consumers. Following the emergence of plants with novel traits into the food supply, many countries are in the process of developing, or have already developed, guidelines for labelling of foods containing ingredients derived from biotechnology in response to consumer concerns relating to foods produced by recombinant DNA techniques. Countries that have already developed labelling guidelines include Australia and New Zealand, whose regulatory standard requires that any ingredient containing more than $1 \%$ of genetically modified product must be labelled as such (Canadian Food Inspection Agency, 2004). The European Union has also adopted regulations for the labelling of foods containing ingredients derived from biotechnology, whereby labelling would be required for food or animal feed containing more than $0.9 \%$ of biotechnology-derived ingredients. In Japan, mandatory labelling is required for foods derived from biotechnology that are not the same as conventional foods in content, nutrition and usage, and for foods that are primarily composed of ingredients derived from biotechnology (i.e., wherever genetically modified ingredients account for more than $5 \%$ of the total weight of the food) (Canadian Food Inspection Agency, 2004). In Canada, while the labelling of genetically modified 
foods is not mandatory, an industry standard for the voluntary labelling of foods derived from biotechnology is currently being developed, whereby a food manufacturer may choose to label a product as either "product of biotechnology" or "not a product of biotechnology" as long as the label is truthful and not in any way misleading to consumers (Canadian Food Inspection Agency, 2006).

A genetically modified organism (GMO) is commonly defined as a living organism whose genetic composition has been altered by means of gene technology, which usually involves the transfer of exogenous DNA into the genome of the target organism that successively becomes a GMO, an event that is referred to as transformation (Miraglia et al., 2004). The inserted DNA, or gene construct, must be integrated into the genome of the host organism in order to become stably inherited, and is usually composed of three specific elements: a promoter, which serves as a controller of gene expression; the inserted or altered gene that codes for the desired trait; and a terminator element, which acts as a stop signal for transcription of the transgene, and is also involved in polyadenylation of transcripts (Fig. 1.1) (Miraglia et al., 2004). 
Promoter (e.g., CaMV 35S)
Transgenic trait gene

(e.g., EPSPS)
Terminator

(e.g. NOS)

$\therefore \because \because \because \because \because \because \cdots \square$

$\because: \because: \because: \because: \because$

Figure 1.1: Simplified representation of a typical transgenic insert (gene construct) containing the necessary regulatory elements for successful integration and gene function. CaMV 35S, Cauliflower Mosaic Virus 35S promoter; EPSPS, 5enolpyruvylshikimate-3-phosphate synthase; NOS, nopaline synthase 
Other methods for modifying DNA in addition to gene technology include chemical and irradiation mutagenesis, in which the expression of the desired trait can result from a single nucleotide change. For example, the imidazolinone herbicidetolerant line of CLEARFIELD ${ }^{\mathrm{TM}}$ rice was developed using chemically induced seed mutagenesis, whereby a single point mutation brought about an amino acid substitition that resulted in an imidazolinone-tolerant phenotype (Canadian Food Inspection Agency, 2002).

In 2005, the year that marked the tenth anniversary of the commercialization of genetically modified crops, approximately 90 million hectares of approved genetically modified crops were planted in seventeen countries worldwide, compared to 1.7 million hectares in 1996 (James, 2005). Of these, genetically modified soybean was the principal GM crop, occupying $60 \%$ of the global GM growing area, followed by GM maize $(24 \%$ of the global GM growing area), cotton (11\%) and canola (5\%), with both herbicide tolerance and insect resistance being the two most dominant GM traits (James, 2005). In response to the imposed labelling guidelines, testing programs for the detection of genetically modified ingredients in foods are being established.

\section{Detection Strategies for Genetically Modified Organisms (GMOs) in foods}

Strategies for the detection of genetically modified elements in foods can generally be divided into two categories: i) methods for the detection of the modified 
DNA sequence(s) directly or, ii) methods for the detection of the modified protein expressed by the transgene. Protein-based detection methods usually employ immunological techniques, such as Enzyme-linked Immunosorbent Assays (ELISAs). These methods will be discussed later in this section. The majority of DNA-based detection methods for the detection of GM ingredients in foods usually employ nucleic acid amplification-based techniques based on the polymerase chain reaction (Saiki et al., 1985, 1988). Such PCR-based methods can be further divided according to their degree of specificity (Table 1.1), with the least specific belonging to screening methods which screen samples for regulatory elements common to many GM crops, such as the constitutive Cauliflower Mosaic Virus 35S promoter sequence (CaMV 35S) used in many GMO constructs; nopaline synthase (NOS) terminator sequences derived from Agrobacterium tumefaciens, also commonly used in many GM plants; or selectable marker genes that are used as indicators to select transformed cells, such as neomycinphosphotransferase II (nptII), a gene that confers resistance to certain antibiotics (e.g. kanamycin) (Hardegger et al., 1999; Lipp et al., 1999; Vollenhofer et al., 1999). Following screening for common GM targets, further analyses are usually performed to target more specific elements, as these screening methods cannot be used to specifically identify a particular GMO. Such analyses include PCR-based methods targeting transgene-specific elements, such as the $\operatorname{cryl}(A(b)$ transgene of the "Maximizer" maize line (event 176, Novartis), which codes for an insecticidal protein derived from Bacillus thuringiensis, and methods targeting the Glyphosate herbicide-tolerant CP4 5enolpyruvylshikimate-3-phosphate synthase (EPSPS) transgene of "RoundUp Ready" soybean (event GTS40-3-2, Monsanto), which codes for a glyphosate-tolerant form of the 
EPSPS plant enzyme isolated from the common soil bacterium, Agrobacterium tumefaciens strain CP4 (Vaitilingom et al., 1999; AGBIOS, 2006). While transgenespecific methods can provide information about the particular GM traits that are present in the sample, such methods cannot reveal the specific identity of a particular GMO, and will therefore not provide any information as to whether the GMO is authorized (Miraglia et al., 2004). Even more specific are the methods targeting construct-specific elements, i.e., amplifying a segment containing both the transgene and a regulatory element such as a promoter or terminator sequence from the inserted gene construct. Construct-specific PCR systems have been described for the detection of transgenic potatoes modified to contain an antisense granule bound starch synthase ( $g b s s)$ gene, which serves to inhibit translation of the naturally occurring gbss-mRNA through silencing by the antisense transcript, resulting in GM potatoes with lower amylose content (Hassan-Hauser et al., 1998). The PCR system was designed to amplify a segment of DNA spanning both the promoter region and the antisense gbss gene of the gene construct. Construct specific methods can identify a particular construct of a specific GMO, and therefore offer a high level of specificity; however, in some instances the same plasmid(s) has been used to transform the same GM trait into different GMOs. Consequently, the same construct may be shared among different GM lines (Holst-Jensen et al., 2003). For example, the four distinct transgenic maize lines MON80100, MON809, MON810 and MON832 all used the same two constructs (PV-ZMBK07 and PV-ZMGT10) in the transformation process, and may not be distinguishable if using construct-specific methods for their detection (BATS, 2003; AGBIOS, 2006). Finally, the most specific methods target event-specific sequences. These methods are targeted towards the amplification of a 
DNA segment spanning the unique junction between the host plant genome and the integrated recombinant DNA sequence, and offer the highest level of specificity. Such systems have been described for the transgenic MON810 event in Yieldgard maize (Monsanto) using a primer pair to amplify a segment of DNA spanning junction between the maize host genome and the 3'-transgene integration sequence of the inserted DNA (Hernandez et al., 2003a). Other event specific PCR systems have been described for StarLink maize (event CBH-351) (Windels et al., 2003); Bt11 maize (Ronning et al., 2003); and RoundUp Ready soybean (Berdal and Holst-Jensen, 2001; Terry and Harris, 2001). 
Table 1.1: Polymerase chain reaction (PCR) based systems for the detection of genetically modified organisms (GMOs) in foods

\begin{tabular}{|c|c|c|}
\hline $\begin{array}{l}\text { Detection System } \\
\text { Category }\end{array}$ & DNA Target & Reference \\
\hline \multirow[t]{2}{*}{ Screening methods } & $\begin{array}{l}\text { Cauliflower Mosaic Virus 35S } \\
\text { promoter; Nopaline Synthase } \\
\text { (NOS) terminator }\end{array}$ & $\begin{array}{l}\text { Hardegger et al., 1999; } \\
\text { Lipp et al., 1999; } \\
\text { Vollenhofer et al., } 1999\end{array}$ \\
\hline & nptII antibiotic marker gene & Vollenhofer et al., 1999 \\
\hline Transgene-specific & RoundUp Ready soybean CP4 & Vaitilingom et al., 1999 \\
\hline methods & $\begin{array}{l}\text { EPSPS; Maximizer maize } \\
\operatorname{cry} l A(b)\end{array}$ & \\
\hline Construct-specific & GM potato variety Desiree: B33 & Hassan-Hauser et al., \\
\hline methods & promoter and antisense gbss & 1998 \\
\hline \multirow[t]{5}{*}{ Event-specific methods } & Yieldgard maize (event & Hernandez et al., 2003a \\
\hline & MON810) & Windels et al., 2003 \\
\hline & StarLink maize (event CBH-351) & Ronning et al., 2003 \\
\hline & Bt11 maize & Berdal and Holst-Jensen, \\
\hline & RoundUp Ready soybean & $\begin{array}{l}\text { 2001; Terry and Harris, } \\
2001\end{array}$ \\
\hline
\end{tabular}


Routine screening for GMOs based on PCR amplification of common elements, such as nptIl, CaMV $35 \mathrm{~S}$ or NOS sequences, has on occasion resulted in the reporting of false positive results due to natural contamination of food plants by the cauliflower mosaic virus (such as rapeseed, broccoli, etc., members of the family Cruciferae that are susceptible to CaMV infection), or through natural contamination by microorganisms containing the NOS terminator sequences harboured by the soil bacterium Agrobacterium tumefaciens (Meyer, 1999; Wolf et al., 2000). Antibiotic resistance gene sequences (e.g. nptII) have been detected in commercially available Taq polymerase preparations (prepared by recombinant DNA techniques) used in the PCR amplification process, and may therefore lead to false-positive reporting when screening for GMOs based on selectable marker gene sequences such as nptII (Perron et al., 2006). Furthermore, as the numbers of genetically modified plants continue to increase, each with their own unique modified trait, uniplex PCR-based methods targeting single genetic targets are becoming increasingly cumbersome to operate due to the large number of possible elements that need to be tested. For example, in Canada alone, there are 20 different varieties of genetically modified maize approved for cultivation, and eight different lines of genetically modified soybean, as well as numerous genetically modified versions of various other common crops (AGBIOS, 2006).

In an attempt to increase the number of GMO targets detectable in a single assay, multiplex PCR assays for the detection of multiple genetically modified elements have been developed. Such assays include: (1) a multiplex PCR method targeting two transgenic screening elements (CaMV 35S and NOS), and endogenous control sequences 
from each of corn and soybean, with amplicon detection using a low density, cloth-based hybridization array system (Blais et al., 2002); (2) a real-time, multiplex PCR system using SYBR Green I dye to distinguish between genetically modified (and endogenous control) sequences from maize and soybean based on differences in the denaturation temperatures of each of the amplification products (Hernandez et al., 2003b); (3) a multiplex PCR system using multiple primer pairs targeting numerous genetically modified sequences (and internal endogenous control sequences to assess the efficiency of each reaction) for the detection of GM maize, soybean and canola, followed by analysis of the PCR products by agarose gel electrophoresis (James et al., 2003). More recently, microarray technology has been adapted for use as a detection system for genetically modified food ingredients, enabling the analysis of multiple targets in a single assay (Germini et al., 2005; Leimanis et al., 2006). Microarray technology utilizes microscopic arrays of oligonucleotide probes immobilized on solid supports. The arrays are typically prepared by covalently attaching numerous oligonucleotide probe sequences to chemically-modified glass surfaces through UV cross-linking, whereby covalent bonds are formed between the thymidine residues of the DNA to the primary amine groups present on the modified glass surfaces of the microarray slides (Zammatteo et al., 2000). The covalently bound DNA probes can be used to capture labelled PCR products for hybridization to the slide, and the hybridized products detected by either colourimetric or fluorogenic means (Germini et al., 2005; Leimanis et al., 2006). However, this technology requires costly materials, labour intensive slide preparation and specialized detection equipment and software, and although microarray technology allows for a vast number of probe sequences to be applied to the slides, the maximum number of targets 
amplifiable in a single multiplex PCR assay will ultimately limit the detection capability of microarray-based systems.

\section{Strategies for the Analysis of PCR-amplified DNA}

PCR-amplified DNA is commonly analyzed by agarose gel electrophoresis followed by staining with ethidium bromide. In this approach, PCR products are identified based on the estimated sizes of the separated amplicons through comparison to a DNA ladder composed of DNA fragments of known lengths. However, non-specific PCR amplification products of similar size to the expected target amplicons can sometimes occur, especially during multiplex PCR where the multiple primer sets present in the reaction can often lead to spurious amplification products (Markoulatos et al., 2002), highlighting the need for further tests to verify the nature of the PCR products. Such methods include specific cleavage of the amplification products by restriction endonuclease digestion, followed by agarose gel electrophoresis to analyze the cleavage pattern of the digested product, or, in certain cases Southern blot analysis of the PCR product by transfer of the agarose gel separated product onto a membrane with subsequent hybridization with a labelled DNA probe specific to the target sequence (Meyer, 1999). Both methods are somewhat time-consuming and labour intensive, especially when multiple samples are being analyzed. In comparison to restriction endonuclease digestion, Southern blot analysis allows for a higher degree of sequence confirmation through the use of DNA probes complementary to the target of interest; however, the method is not well suited for the analysis of numerous products of similar 
size that may arise from a multiplex PCR amplifying numerous targets. Additionally, utilization of the restriction endonuclease approach for analysis of amplicons arising from a multiplex PCR can lead to complex banding patterns which can be difficult to interpret.

Dot blot hybridizations are often preferred in cases where agarose gel electrophoresis of the amplified products may not be possible, i.e., in instances where multiple bands of similar size are being analyzed, or when numerous samples are being processed. In this method, labelled oligonucleotide probes are used as detector molecules that hybridize to amplified DNA targets immobilized onto a solid microporous matrix, such as nitrocellulose or nylon (Saiki et al., 1986; Inouye and Hondo, 1990). In such systems, each labelled-probe is individually hybridized to the immobilized, amplified DNA; a process that can become rather cumbersome should numerous probes be required. Saiki et al. (1989) addressed this issue by reversing the hybridization approach, whereby unlabelled oligonucleotide probes were immobilized on a nylon membrane to capture labelled PCR products. Microporous membranes such as nylon and nitrocellulose are effective as solid matrices for use in DNA hybridization procedures; however, they are rather expensive, nitrocellulose is quite fragile and both types of membrane are thin, allowing only very small volumes of sample to be applied per unit of surface. Additionally, because of the microporous nature of the membrane matrix, which hinders the free movement of macromolecules, it can often be difficult to remove unreacted reagents from these membranes, necessitating long periods of immersion and numerous changes of wash buffer between reaction steps (Blais and Phillippe, 1995). 
Furthermore, utilization of these microporous membranes necessitates long hybridization reactions (typically several hours).

Polyester cloth has been shown to be an effective and inexpensive solid phase for the adsorption of antibodies and antigens in immunoassay applications (Blais et al., 1989) and can also serve as an effective solid phase for nucleic acid probe hybridizations (Blais and Phillippe, 1995). This macroporous matrix provides a high surface area for immunoreagent adsorption, enabling rapid reaction kinetics, and also exhibits excellent flow characteristics due to the large spaces between the fibres constituting the matrix, facilitating ease of washing through the use of a simple vacuum apparatus to remove unbound reagents between reaction steps (Blais and Phillippe, 1995). In comparison to commonly used microporous solid matrices, such as nylon or nitrocellulose, the greater thickness of polyester cloth facilitates the adsorption of a larger volume of sample per unit of surface, while still resulting in compact and well-resolved sample spots. The use of macroporous polyester cloth as an effective solid phase in the development of simple DNA array hybridization methods based on the reverse dot-blot principle has been previously reported for the detection of multiplex PCR products by hybridization with immobilized DNA probes. In this cloth-based hybridization array system (CHAS), amplicons incorporating digoxigenin-labeled dUTP are detected by hybridization with an array of specific oligonucleotide probes immobilized in discrete spots on a polyester cloth strip, followed by sequential reactions of the strip with anti-digoxigenin antibodyperoxidase conjugate and chromogenic substrate solution (Fig. 1.2). CHAS methods have been developed for the detection and identification of transgenes in genetically 
modified crops (Blais et al., 2002), multiple antibiotic resistance genes in Salmonella Typhimurium DT104 isolates from foods (Gauthier and Blais, 2004), Clostridium botulinum neurotoxin genes (Gauthier et al., 2005), and remnants of prohibited animal species in feedstuffs (Armour and Blais, 2006). 
Food sample (extracted and quantified DNA)

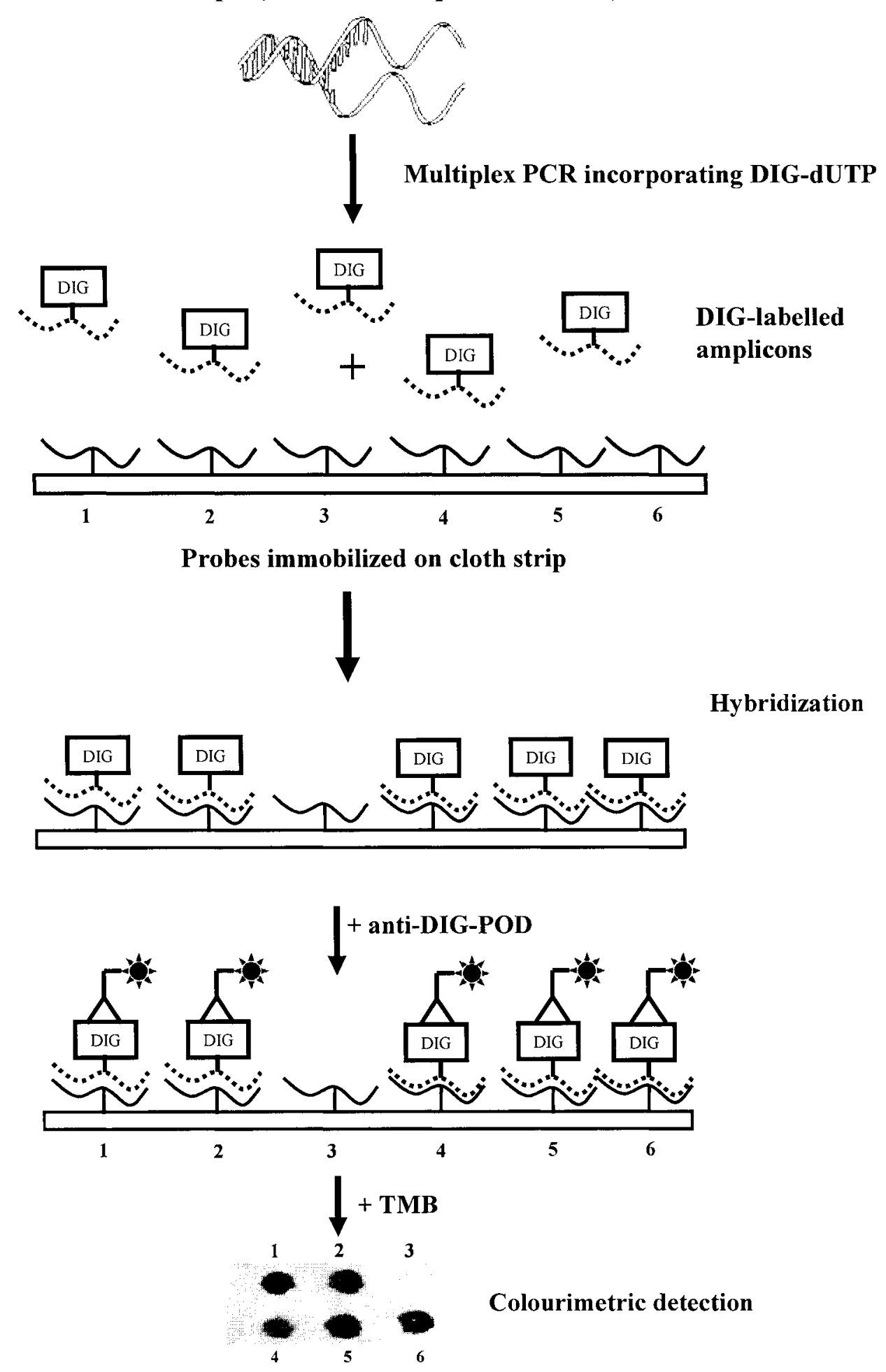

Figure 1.2: Schematic representation of the Cloth-based Hybridization Array System (CHAS) 


\section{Protein-based detection methods}

In certain instances, it may be desirable to use protein detection methods for the identification of genetically modified ingredients in foods; yet most protein-based assays are often limited in terms of their detection sensitivity. The development of ultrasensitive assays for the detection of proteins in foods is important because food matrices can be highly processed through heating, pressurization and sterilization, and often contain only trace amounts of protein in a detectable form. Current protein-based detection methods for genetically modified elements include the Cry9C Agri-Screen $\circledR^{\circledR}$ Strip Test (Neogen Corporation) for StarLink corn (Aventis CropScience), a crop that was genetically modified to contain a gene coding for the Cry9C protein, an insecticidal toxin derived from the common soil bacterium Bacillus thuringiensis subsp. Tolworthi, which makes this variety more resistant to certain types of corn insect pests. The Cry9C protein encoded by the transformed gene was more resistant to heat and digestion than were other Cry proteins, possibly resulting in a longer exposure time to the immune system by this protein following ingestion, a factor giving the $\mathrm{Cry} 9 \mathrm{C}$ protein the potential to be allergenic (Diaz et al., 2002). Therefore, the U.S. Environmental Protection Agency prohibited this variety from entering the human food chain, but approved StarLink corn for use in animal feed and industry (Diaz et al., 2002). However, in September 2000, traces of StarLink corn DNA were found in taco shells destined for human consumption following analysis of the samples by polymerase chain reaction targeting $\operatorname{Cry} 9 \mathrm{C}$-specific gene sequences, resulting in a massive food recall of the affected commodities (Trucksess, 2001). While many analytical methods based on the polymerase chain 
reaction have been developed for the detection of sequences specific to the $\mathrm{Cry} 9 \mathrm{C}$ gene (Orlandi et al., 2002; Quirasco et al., 2004), the detection of Cry9C DNA is not necessarily indicative of the presence of the Cry9C protein that may elicit an allergenic response in certain individuals, emphasizing the importance and relevance of proteinbased detection systems. The Agri-Screen ${ }^{\circledR}$ Strip Test (Neogen) for StarLink corn Cry9C protein exhibits a reported detection sensitivity of one kernel of StarLink corn among 800 non-StarLink kernels (Neogen, 2001); however, most commercial kits focus on the detection of the Cry9C protein in relatively clean and unprocessed samples (Diaz et al., 2002). EnviroLogix ${ }^{\mathrm{TM}}$ developed a commercial sandwich enzyme-linked immunosorbent assay (sELISA) test kit for the detection of Cry9C protein in corn grain or seed. The principle of the assay was to react extracted proteins from a corn product test sample with the wells of a microtiter plate that are coated with antibodies raised against the Cry9C endotoxin to specifically capture the protein (if present) from the corn product sample extracts added to each of the wells. Following a wash step, any bound Cry9C protein is reacted with horseradish-peroxidase labelled antibodies specific to Cry9C, followed by another wash step and subsequent detection using a chromogenic substrate solution that is converted to a coloured product by the peroxidase enzyme, where the extent of colour development is in direct proportion to the amount of Cry9C protein originally present in the test sample (Trucksess, 2001; EnviroLogix, 2006). Upon evaluation of the EnviroLogix ${ }^{\mathrm{TM}}$ ELISA kit for Cry9C protein detection, Diaz et al. (2002) found that only a very small amount $(0-0.5 \%$, depending on the degree of food processing) of detectable Cry9C protein remains in a food product made from $100 \%$ StarLink corn after processing, highlighting the need for the development of highly 
sensitive detection assays for genetically modified protein in processed foods, especially if the target of interest is present as a minor ingredient in a highly processed, mixed food sample.

\section{$\underline{\text { Objectives }}$}

\section{(1) Cloth-based hybridization array system for common food crops (Crop-} CHAS).

As the number of transgenic elements that are introduced into different plant crops continues to increase, the traditional approach of applying single target-specific PCR methods for the detection of genetically modified organisms in foods will become increasingly impractical. For many crop species there are numerous possible transgenic elements; therefore, in a mixed food sample containing multiple crop ingredients, the number of different possible transgenic elements to test for can become rather cumbersome. Consequently, there is a need to minimize the number of possible choices of individual, target-specific tests that need to be carried out to make testing of foods more practical. A tiered approach is hereby proposed, wherein a limited number of tests are conducted on a food sample to determine, first, which specific crop ingredients are present (in terms of amplifiable DNA), followed by further testing for known transgenic elements relevant to the specific ingredients detected in the food sample. 
In the quest to provide a preliminary screening tool to ascertain which ingredients are present in a mixed food sample, this thesis addresses the development of a clothbased hybridization array system (CHAS) for the detection of amplifiable, specific endogenous gene sequences in corn (Zea mays), soy (Glycine max), rice (Oryza sativa), wheat (Triticum aestivum), and potato (Solanum tuberosum). These plants represent a selection of common food crops for which genetically modified versions have been approved for cultivation in (or import into) Canada, and are therefore the most likely ingredients to harbour transgenic elements in a mixed food sample. Utilization of this assay as a preliminary screening tool would confirm which crops are present in a food sample prior to analyzing the sample for crop-specific transgenic events, and would also serve as an indicator of the amplifiability of the DNA from specific crop species. Determination of the amplifiability of target DNA is an essential element in assuring the validity of PCR-based GMO testing, since transgenic sequences can only be detected if sample DNA is in an amplifiable state.

\section{(2) Microplate fluorescence assay for DNA quantification.}

In operating nucleic acid amplification methods, it is necessary to have an accurate means of quantifying DNA to be used as template in the PCR. The quantity of DNA to be used as template in the PCR should be limited to below 100 or $200 \mathrm{ng}$, as too great a concentration of template tends to have an inhibitory effect on the reaction (Miraglia et al., 2004). Additionally, in highly processed samples such as foods, extraction procedures can result in very low yields of DNA, necessitating sensitive DNA 
quantification procedures that utilize low sample volumes for analysis. Different DNA extraction and purification procedures can result in DNA preparations containing varied amounts of impurities, highlighting the need for DNA quantification procedures that are unaffected by the presence of impurities that may be co-extracted with the DNA sample. Spectrophotometry is the standard method for estimating the concentration and purity of nucleic acids by measuring the absorbance at wavelengths of $260 \mathrm{~nm}$ and $280 \mathrm{~nm}$, yet this method may not be favourable for routine measurements due in part to the large sample volume requirements of most spectrophotometers and to the rather insensitive limit of detection of this method. Additionally, Wilfinger et al. (1997) demonstrated that factors such as $\mathrm{pH}$ and the presence of salts in nucleic acid-containing solutions had a significant impact on both the A260/280 ratio and the calculated concentration of the preparations. Therefore, only highly purified DNA preparations may be accurately quantified by spectrophotometry.

To overcome the limitations of traditional DNA quantification methods, this thesis addresses the development of a new microplate assay utilizing the highly sensitive fluorescent stain SYBR Green I for DNA quantification in which fluorescence is quantified by measurement with a fluorescence plate reader. In this microplate fluorescence assay (MFA), the use of a 96-well format permits processing large numbers of samples using minimal quantities of sample DNA and reagents. The performance characteristics of the MFA will be compared with spectrophotometry based on ultraviolet absorption and to the fluorescence-based, Hoefer DyNA Quant $®$ assay. 


\section{(3) An Internal Amplification Control System for PCR.}

In addition to the requirement for an accurate and sensitive method to quantify DNA to be used as template in nucleic acid amplification techniques, it is often necessary to verify the amplification efficiency of the PCR process, as PCR inhibitors can often be present in DNA extracts from complex sample matrices such as foods (Rossen et al., 1992). Many quality assurance schemes require that the presence of inhibitors be determined to validate PCR test results by incorporation of an internal amplification control in the PCR system. For this purpose, special DNA preparations have been devised for addition to the PCR mixture or test sample, along with the corresponding primers, in order to control for the presence of inhibitors on the basis of amplification (Sachadyn and Kur, 1998; Jones et al., 2000; Abdulmawjood et al., 2002; Delcenserie et al., 2005). However, for each of these specialized DNA preparations, the construction of the template to be used as the IAC was relatively complex and labour intensive, and extensive optimization was required to ensure that the amplification efficiency of the target PCR was not affected. Furthermore, the creation of different IACs was required for each unique PCR target.

As an indicator of PCR amplification efficiency, this thesis addresses the development of an exquisitely simple internal amplification control (IAC) system based on the incorporation of oligonucleotide primers with complementary $3^{\prime}$ ends in the PCR mixture. During PCR, these primers should anneal and form a small "primer-dimer"-like product. This product can be detected in a CHAS assay format by hybridization with one 
of the IAC primers immobilized on polyester cloth serving as a capture probe for the IAC amplicon.

\section{(4) Ultrasensitive protein detection methods: Development of the ImmunoScript} Assay.

In certain instances, it may be desirable to use protein detection methods, such as enzyme-linked immunosorbent assays (ELISAs), for the identification of genetically modified ingredients in foods. However, most protein-based assays are often limited in terms of their detection sensitivity, and are therefore not suited for the analysis of highly processed samples, such as foods, that may contain only trace amounts of protein in a detectable form. When nucleic acid amplification techniques are used for signal generation in antibody-based assays, such as in Immuno-PCR, the detection sensitivity of the conventional immunoassay can be dramatically increased (Sano et al., 1992).

This thesis addresses initial attempts to develop an ultrasensitive assay system employing a synthetic transcribable DNA fragment as an indicator molecule to label antibodies for enzyme immuno-assay (EIA) applications enabling the detection of trace amounts of protein in complex, highly processed food samples. It is surmised that a transcribable DNA fragment can be generated during PCR synthesis using a primer bearing an additional sequence of nucleotides specific for a bacteriophage promoter region. This DNA fragment bearing the upstream bacteriophage promoter can then be efficiently converted to multiple RNA copies in an in vitro transcription reaction (Blais, 
1994), and these RNA transcripts may be very sensitively detected using a fluorescent dye that exhibits higher fluorescence intensity when bound to single-stranded RNA than when bound to double-stranded DNA, or by utilizing a suitable molecular beacon probe that exhibits fluorescence only when bound to its RNA target. As an alternative detection mechanism, it is further surmised that amplification of the transcription signal may be enhanced using Nucleic Acid Sequence-Based Amplification (NASBA), an isothermal amplification reaction that is capable of exponentially amplifying RNA, which can be subsequently detected with a suitable fluorescent dye or molecular beacon probe with signal detection using a fluorescence plate reader. The preliminary results of this work are presented in Appendix A of this thesis. 


\section{Chapter 2}

Microplate fluorescence assay for the quantification of double stranded DNA using SYBR Green I dye

"This chapter has been published in a peer-reviewed scientific journal:

Leggate, J., R. Allain, L. Isaac, and B.W. Blais. (2006) Biotechnol. Lett. 28:1587-1594.” 


\section{ABSTRACT}

A high-throughput, 96-well microplate fluorescence assay (MFA) was developed for DNA quantification using the double-stranded DNA-binding dye SYBR Green I. Samples mixed with SYBR Green I in the wells of a microtiter plate produced fluorescence in proportion with DNA concentration which was measured using a fluorescence plate reader. The performance characteristics of the assay were compared with spectrophotometric quantification based on ultraviolet absorption and the Hoefer DyNA Quant assay utilizing the fluorescent dye, Hoechst 33258. The MFA accurately quantified different types of DNA over a broad linear dynamic range of concentrations $(0.25$ to $2500 \mathrm{pg} / \mu \mathrm{l})$, and was not affected by a variety of contaminants in the assay mixture.

\section{INTRODUCTION}

The accurate determination of nucleic acid concentration in solution is a critical operation in molecular biology. Spectrophotometry based on ultraviolet absorption is the most widely practiced method for determining the concentration of DNA in solution, but is limited by the requirement for large sample volumes, narrow dynamic range, and poor detectability. Free nucleotides, single-stranded nucleic acids, such as RNA, and proteins exhibit significant absorbance at $260 \mathrm{~nm}$, and any contamination of the sample preparation by these agents will result in over-estimation of the DNA concentration (Sambrook \& Russell, 2001). Furthermore, Wilfinger et al. (1997) demonstrated that factors such as $\mathrm{pH}$ and the presence of salts have a significant impact on the calculation 
of DNA concentration. Therefore, only highly purified DNA preparations may be accurately quantified by spectrophotometry.

Sensitive fluorometric DNA assays have been developed using specific dyes exhibiting enhanced fluorescence intensity when bound to double-stranded DNA (dsDNA), such as Hoechst 33258 (Labarca \& Paigen 1980), PicoGreen (Ahn et al. 1996, Singer et al. 1997) and SYBR Green I (Vitzthum et al. 1999). The dsDNA binding dye Hoechst 33258 used in conjunction with the Hoefer DyNA Quant 200 Fluorometer can detect as little as $20 \mathrm{ng}$ DNA in a $2 \mathrm{ml}$ sample (Teare et al. 1997). However, this dye has a preference for AT-rich sequences and is therefore sensitive to the DNA composition (Cesarone et al. 1979, Gallagher 2004). Furthermore, the detectability of this method is limited by the length of the DNA sequence, as DNA fragments shorter than 200 bp may not have the minimum number of consecutive AT base pairs required for efficient Hoechst dye binding (Teare et al. 1997).

PicoGreen reagent (Molecular Probes, Eugene, OR) is an alternative dsDNA binding dye which has been used in a 96-well microplate assay format, exhibiting a detectability of $250 \mathrm{pg} / \mathrm{ml}$ (Singer et al., 1997). The assay was not affected by the base content of the DNA sample or by common DNA contaminants such as salts, proteins, and alcohol. However, to be effective high concentrations of dye are required, which adds considerably to the cost of the assay. 
SYBR Green I is another dsDNA binding dye with similar characteristics to PicoGreen. Vitzthum et al. (1999) developed a SYBR Green I-based DNA assay using a standard ultraviolet transilluminator gel imaging system for visualization of fluorescence in the wells of a microtiter plate. Detection of dsDNA was achieved from $2 \mathrm{ng} / \mathrm{ml}$ to 2 $\mu \mathrm{g} / \mathrm{ml}$ and was not significantly affected by the presence of various DNA contaminants. However, the detectability $(2 \mathrm{ng} / \mathrm{ml})$ was inferior to that of the PicoGreen $®$ assay. Moreover, assay performance was dependent on the relative position of the microplate on the transilluminator in relation to the camera, and optimal exposure times were dependent on sample concentrations, making it difficult to standardize this procedure. Comparing four different fluorophores for DNA quantification, Rengarajan et al. (2002) concluded that SYBR Green I and PicoGreen ${ }^{\circledR}$ were substantially more sensitive than Hoechst 33258 or ethidium bromide, and that SYBR Green I and PicoGreen ${ }^{\circledR}$ exhibited almost identical detectabilities, with SYBR Green I being approximately 30-times less expensive than PicoGreen ${ }^{\circledR}$ at the effective working concentration.

To improve the precision of DNA quantification utilizing SYBR Green I, a microplate assay format in which fluorescence is quantified by measurement with a fluorescence plate reader was developed. In this microplate fluorescence assay (MFA), the use of a 96-well format permits processing large numbers of samples using minimal quantities of sample DNA and reagents. The performance characteristics of the MFA were compared to spectrophotometry based on ultraviolet absorption and the Hoefer DyNA Quantß assay. 


\section{MATERIALS \& METHODS}

\section{Nucleic Acids}

Calf thymus DNA (ctDNA) (GE Healthcare) was reconstituted in TE buffer (10 mM Tris-HCl, $1 \mathrm{mM}$ EDTA, pH 8.0) to $1 \mathrm{mg} / \mathrm{ml}$. Lambda phage DNA ( $\lambda$ DNA) (New England Biolabs) was supplied at $500 \mu \mathrm{g} / \mathrm{ml}$ in TE buffer. For the generation of a $217 \mathrm{bp}$ PCR product based on the soy lectin gene, transgenic soy (Roundup Ready, variety S14M7RR) seeds were used for the preparation of template DNA as previously described (Lipp et al., 1999). Ten $\mu \mathrm{l}$ of template $(1 \mathrm{ng} / \mu \mathrm{l})$ was added to $90 \mu \mathrm{l}$ reaction mixture with 2.5 units HotStar Taq and 1 X PCR buffer containing $1.5 \mathrm{mM} \mathrm{MgCl}_{2}$ (Qiagen Inc.), 200 $\mu \mathrm{M}$ each dNTP (Promega Corporation) and $0.4 \mu \mathrm{M}$ each of primers Ltn-1 and Ltn-5 (Blais et al., 2002). The PCR was performed using a Mastercycler gradient thermal cycler (Eppendorf, Westbury, NY) using the following program: initial heating at $94^{\circ} \mathrm{C}$ for $15 \mathrm{~min} 30 \mathrm{~s}$, followed by 40 cycles of denaturation at $94^{\circ} \mathrm{C}$ for $36 \mathrm{~s}$, annealing at $55^{\circ} \mathrm{C}$ for $1 \mathrm{~min} 12 \mathrm{~s}$ and primer extension at $72^{\circ} \mathrm{C}$ for $1 \min 24 \mathrm{~s}$. A final extension at $72^{\circ} \mathrm{C}$ for 3 min followed the last cycle. After amplification, PCR products were pooled and purified using the QIAquick PCR Purification kit (Qiagen), following the manufacturer's instructions

\section{DNA Quantification Methods}

\section{Microplate Fluorescence Assay (MFA)}

A six point series of DNA concentration standards (100 $\mu$ l each) ranging from 0 to 2 $\mathrm{ng} / \mu \mathrm{l}$ was prepared starting with a $2 \mathrm{ng}$ calf thymus or Lambda DNA/ $\mu$ l solution of 
serially diluted in TE buffer in the wells of a Black Microfluor I microtiter plate (Thermo Labsystems, Helsinki, Finland) and mixed with an equal volume (100 $\mu$ l) of SYBR Green I (Cambrex Bio Science) diluted 1:1250 in TE buffer to give a final volume of $200 \mu 1$ per well. For the assay of test samples, $2 \mu \mathrm{l}$ sample were diluted in $98 \mu \mathrm{l}$ TE buffer in the microplate wells and mixed with $100 \mu \mathrm{l} \mathrm{SYBR}$ Green I dye as above. The plates were incubated for $10 \mathrm{~min}$ in the dark at room temperature, and the fluorescence in each well was measured using a fluorescence plate reader fitted with a $485 / 518 \mathrm{~nm}$ excitation/emission filter set. A standard curve was generated by plotting fluorescence units versus the DNA concentration for a series of DNA concentration standards. The DNA concentration of the test sample was calculated by inputting the fluorescence value into the equation for the standard curve (Fig. 2.1, inset) and solving for the quantity X (DNA concentration in the microplate well). This value was multiplied by 100 (the dilution factor, since $2 \mu \mathrm{l}$ of sample were added to a final volume of $200 \mu \mathrm{l}$ ) to obtain the starting DNA concentration of the test sample.

\section{Hoefer DyNA Quant ${ }^{\circledR} 200\left(\right.$ DyNA Quant $\left.{ }^{\circledR}\right)$}

Samples were analyzed following the manufacturer's instructions for the low range assay as described in the DyNA Quant ${ }^{\circledR} 200$ fluorometer user manual (GE Healthcare). Briefly, the instrument was calibrated by adding $2.0 \mu \mathrm{l}$ of a $100 \mathrm{ng} / \mu \mathrm{l}$ ctDNA standard to $2.0 \mathrm{ml}$ of $1 \mathrm{X}$ TNE buffer (0.2 M NaCl, $10 \mathrm{mM}$ Tris HCl, $1 \mathrm{mM}$ EDTA, pH 7.4) containing $0.1 \mu \mathrm{g} / \mathrm{ml}$ Hoechst 33258 (GE Healthcare) in a 2-ml capacity fluorometrygrade glass cuvette (GE Healthcare) and the fluorescence of the sample measured using the Hoefer DyNA Quant ${ }^{\circledR} 200$ fluorometer (GE Healthcare). For the assay of test 
samples, $2 \mu \mathrm{l}$ of sample were added to $2 \mathrm{ml}$ TNE buffer containing $0.1 \mu \mathrm{g}$ Hoechst $\mathrm{dye} / \mathrm{ml}$ and the fluorescence measured as above.

\section{BioMate 3 Spectrophotometer}

Samples were analyzed following the manufacturers' instructions for quantification of nucleic acids using the Thermo Spectronic BioMate 3 Spectrophotometer (Thermo Labsystems). Briefly, $70 \mu \mathrm{l}$ of sample were added to a quartz cuvette and the $\mathrm{A}_{260}$ to $\mathrm{A}_{280}$ ratio of each sample were measured against a TE blank. DNA concentration was determined on the basis of $1 \mathrm{~A}_{260}$ unit corresponding to $50 \mu \mathrm{g} / \mathrm{ml}$ of double-stranded DNA (Sambrook \& Russell 2001).

\section{Determination of Dose-Response Characteristics}

Serial dilutions of ctDNA or $\lambda$ DNA ranging from 2.0 to $500 \mathrm{ng} / \mu \mathrm{l}$ in TE buffer were used to determine the linear range, precision, detectability and accuracy for the different quantification methods. The limit of detection [LOD, defined as the mean value of a sample blank plus three standard deviations $(\mathrm{SD})(\mathrm{n}=7)]$ and the limit of quantification [LOQ, defined as the mean value of a sample blank plus $10 \mathrm{SD}(\mathrm{n}=7)]$ were calculated for the MFA.

\section{RESULTS AND DISCUSSION}

\section{Performance characteristics}

The performance characteristics of a new microplate fluorescence assay (MFA) based on the reaction of sample DNA with SYBR Green I and subsequent measurement of 
fluorescence using a fluorescence plate reader was compared with standard ultraviolet absorption and the commercial DyNA Quant ${ }^{\circledR}$ fluorescence assay. Calf thymus DNA (ctDNA) was used as a representative high complexity DNA sample in assessing the detectability, accuracy and precision of the three quantification methods. A DNA concentration series was prepared in TE buffer and assayed in triplicate using the three quantification methods over a range of concentrations. In the ultraviolet absorption technique, the absorbance of the DNA sample was measured at $260 \mathrm{~nm}$ and the DNA concentration calculated using the relationship of $1 \mathrm{~A}_{260}$ unit corresponding to $50 \mu \mathrm{g}$ double-stranded DNA/ml. In the DyNA Quant ${ }^{\circledR}$ method, the fluorescence intensity of a sample reacted with Hoechst 33258 dye was automatically converted to a DNA concentration after calibration of the instrument with a $100 \mathrm{ng} / \mu \mathrm{l}$ ctDNA standard. For the MFA method, a standard dose-response curve was generated by plotting fluorescence versus DNA concentration for a series of ctDNA concentration standards, followed by linear regression analysis in order to obtain an equation for the line (Fig. 2.1, inset). A separate series of DNA preparations covering a range of different concentrations was analysed by the MFA, and the DNA concentration calculated using the equation for the standard curve (Fig. 2.1). The degree of accuracy of each method was judged by the agreement between the calculated (y-axis) and known (x-axis) DNA concentrations. Precision was ascertained on the basis of the coefficient of variation (CV) obtained for each DNA concentration (shown above the columns in Fig. 2.1). 


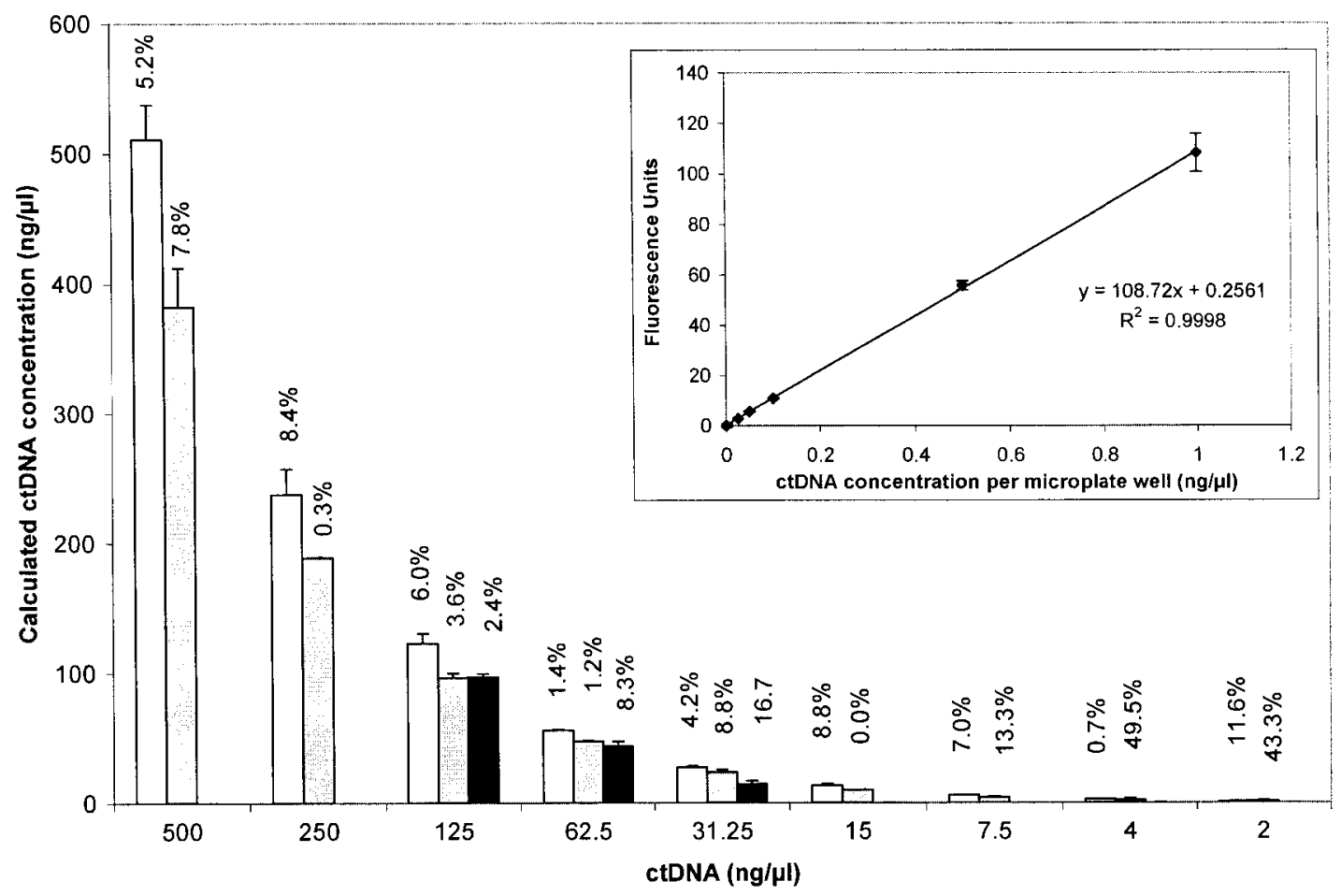

Figure 2.1. Comparison of the performance characteristics of the three DNA quantification methods using calf thymus DNA. Different concentrations of ctDNA were subjected to the MFA (white), DyNA Quant $\AA$ (grey) and ultraviolet absorption (black) methods. DNA concentrations for the MFA were calculated using the equation for a standard dose-response curve obtained with a separate set of ctDNA concentration standards (inset). Results are expressed as the mean calculated ctDNA concentration \pm standard deviation $(n=3)$, and the coefficient of variation is shown above each column. 
The MFA and DyNA Quant ${ }^{\circledR}$ methods were responsive over the entire range of the ctDNA concentrations tested ( 2.0 to $500 \mathrm{ng} / \mu \mathrm{l})$, with slightly better accuracy being demonstrated by the MFA (Fig. 2.1). The precision of the MFA and DyNA Quant ${ }^{\circledR}$ methods did not differ substantially at the higher DNA concentrations, but was worse for the latter method at the lower concentrations ( 2.0 to $7.5 \mathrm{ng} / \mu \mathrm{l})$. The ultraviolet absorption method exhibited a very narrow dynamic range (30 to $125 \mathrm{ng} / \mu \mathrm{l}$ ). Similar performance characteristics were observed for all three methods when Lambda DNA was used as the analyte and for construction of the standard curve instead of calf thymus DNA (Fig. 2.2).

Based on the promising results observed using the MFA, the range of the standard curve was extended to include very low concentrations of ctDNA. A plot of fluorescence versus ctDNA concentration gave a linear dose response curve $\left(\mathrm{R}^{2}=0.9997\right)$ from 0.25 to $2500 \mathrm{pg} / \mu \mathrm{l}$ of ctDNA per well (Fig. 2.3). The LOD and LOQ were calculated as 0.25 and $1.25 \mathrm{pg} / \mu \mathrm{l}$, respectively, for the detection of ctDNA using the MFA. 


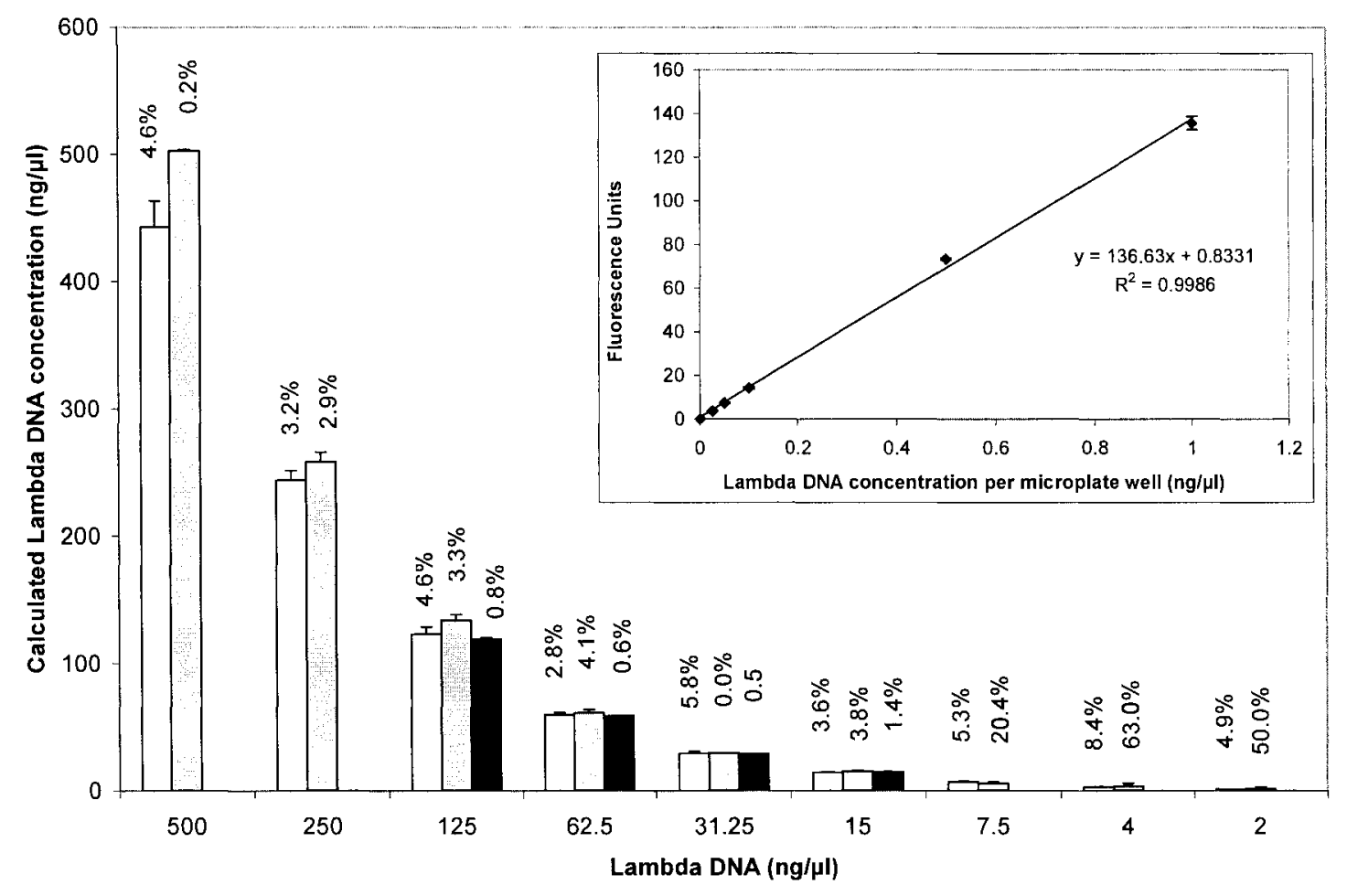

Figure 2.2. Comparison of the performance characteristics of the three DNA quantification methods using bacteriophage Lambda DNA. Different concentrations of Lambda DNA were subjected to the MFA (white), DyNA Quant ${ }^{\circledR}$ (grey) and ultraviolet absorption (black) methods. DNA concentrations for the MFA were calculated using the equation for a standard dose-response curve obtained with a separate set of lambda DNA concentration standards (inset). Results are expressed as the mean calculated lambda DNA concentration \pm standard deviation $(n=3)$, and the coefficient of variation is shown above each column. 


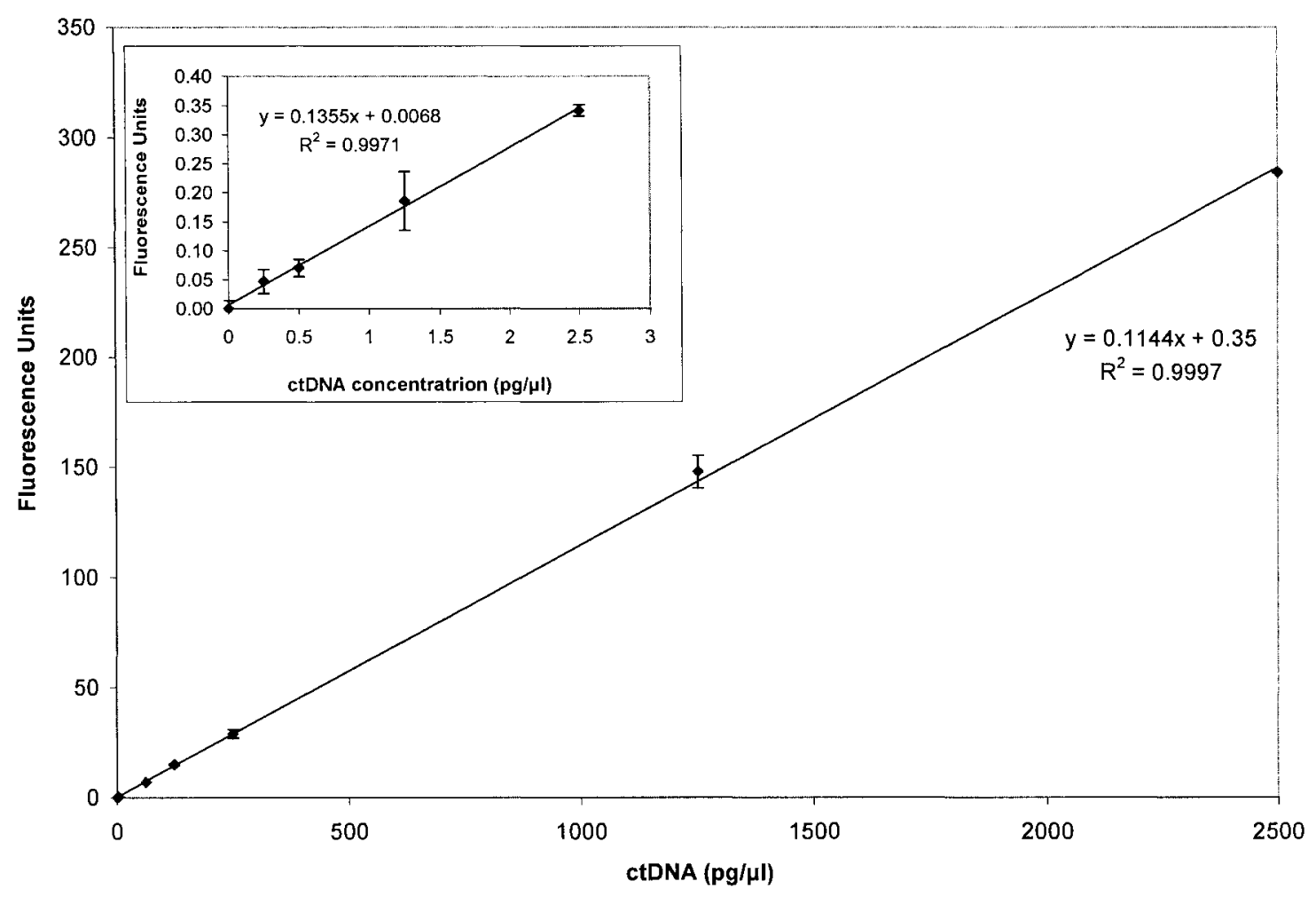

Figure 2.3. Dose response characteristics of the MFA over a broad range of calf thymus DNA concentrations. An extended dilution series of ctDNA was mixed with SYBR Green I (final concentration of 1:2500) and the resulting fluorescence was measured. Results are expressed as the mean calculated fluorescence units \pm standard deviation $(\mathrm{n}=3)$. The inset shows an enlargement of the results obtained with DNA below $2.5 \mathrm{pg} / \mu 1$ per microplate well. 


\section{Quantification of PCR product}

The preceding experiments demonstrate the performance characteristics of the MFA using relatively large, complex types of DNA. There are many instances when it is desirable to quantify smaller DNA fragments such as PCR products. The performance of the three methods was verified in the assay of a PCR amplicon (217 bp) derived from the soy lectin gene serially diluted in TE buffer. The calculated concentration was plotted against the PCR product dilution (expressed as the percentage DNA of the starting preparation in a two-fold dilution series) (Fig. 2.4). DNA concentrations for the MFA were calculated using the equation for a standard dose-response curve obtained with a series of ctDNA concentration standards as before.

The MFA and DyNA Quant ${ }^{\circledR}$ methods exhibited acceptable correlation coefficients $\geq 0.99$ (Fig. 2.4, inset), demonstrating the excellent linearity of these methods, while the UV absorption method exhibited a correlation coefficient of 0.9624 for the curve describing the entire range of concentrations (Fig. 2.4, inset), which is indicative of poor linearity. A correlation coefficient of 0.9999 was obtained over the 25 to $100 \%$ range using the UV absorption method, indicating better linearity over this limited range of concentrations (not shown). No significant ultraviolet absorption was measured with samples containing less than $3.0 \%$ of the PCR product, while the MFA and DyNA Quant ${ }^{\circledR}$ methods permitted quantification with as little as $0.75 \%$ of the PCR product. The MFA exhibited better precision (lower CV values) than the other two methods at PCR product concentrations of $25 \%$ and less (Fig. 2.4). 


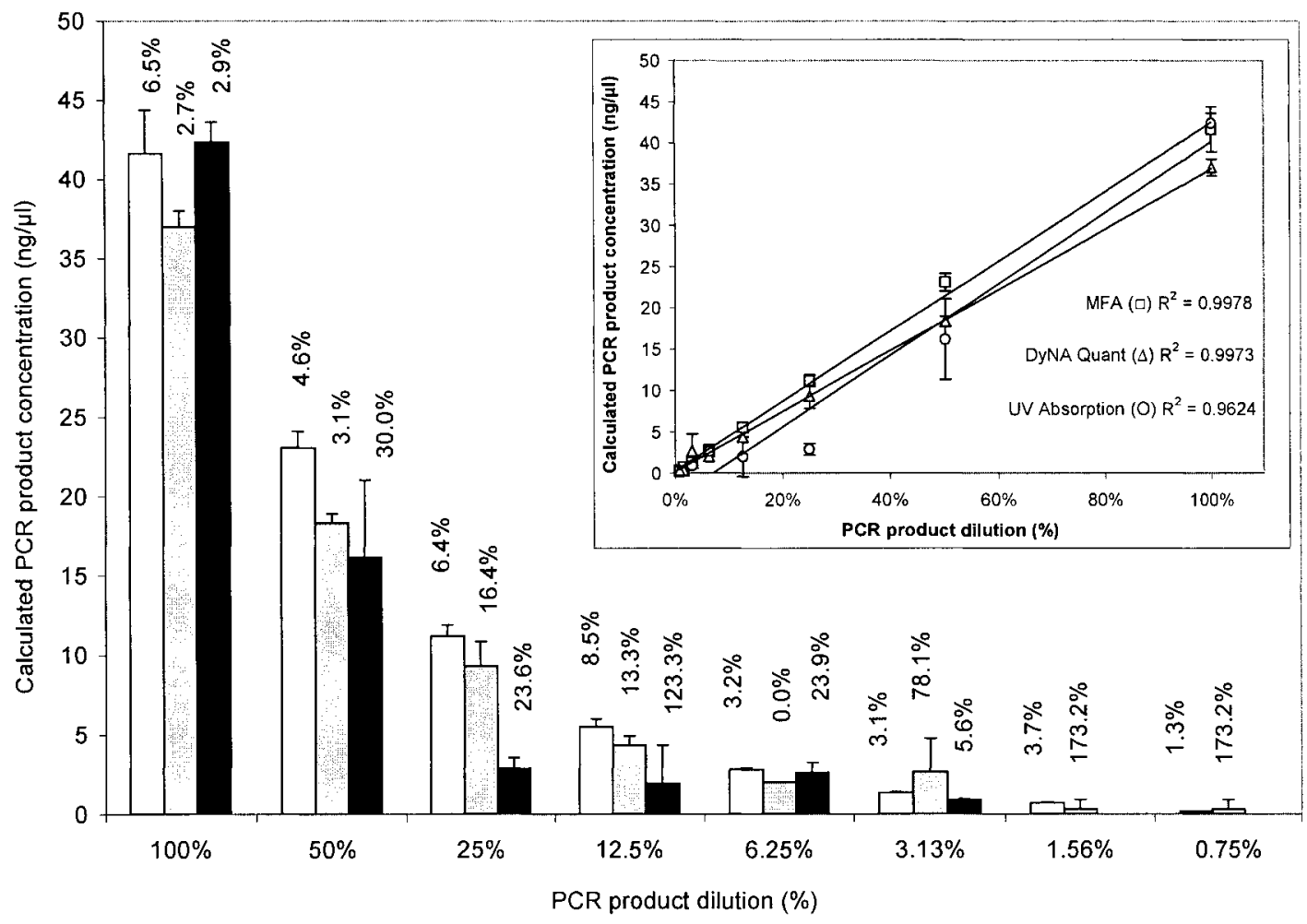

Figure 2.4. Comparison of the performance characteristics of the three DNA quantification methods. A two-fold dilution series of purified PCR product was subjected to the MFA (white), DyNA Quant ${ }^{\circledR}$ (grey) and ultraviolet absorption (black) methods. Results are expressed as the mean calculated PCR product concentration \pm standard deviation $(\mathrm{n}=3)$, and the coefficient of variation is shown above each column. The inset shows the linearity of the MFA (squares), DyNA Quant $\mathbb{R}$ (triangles) and UV absorption (circles) methods. 


\section{Effect of contaminants on DNA quantification}

DNA preparations from biological samples can contain a variety of different contaminants derived from either the sample matrix or reagents used in the purification process. Contaminants such as salts, alcohols, detergents, proteins and nucleic acids may mediate positive or negative interference with DNA measurement (Sambrook \& Russell 2001). Therefore, it was necessary to verify the performance of the MFA with DNA samples containing different levels of various contaminating agents. A standard curve using calf thymus DNA was generated for each experiment, as before, and DNA concentrations were calculated for a $50 \mathrm{ng} / \mu 1$ solution of ctDNA in the presence of various levels of each contaminant.

BSA, 2-propanol, $\mathrm{KCl}$, and phenol did not appreciably affect DNA quantification at the different contaminant concentrations tested (Fig. 2.5). The presence of a 10-fold excess $(500 \mathrm{ng} / \mu \mathrm{l})$ of RNA resulted in overestimation of the calculated DNA concentration by approximately $30 \%$, but an equivalent amount $(50 \mathrm{ng} / \mu 1)$, or less, did not interfere with DNA quantification. A concentration of $0.1 \% \mathrm{v} / \mathrm{v}$ SDS in the final assay volume caused a decrease in the calculated DNA concentration by approximately $90 \%$, while $0.01 \% \mathrm{v} / \mathrm{v}$ SDS did not affect quantification. The presence of oligonucleotide primers (Ltn-1 and Ltn-5) added at about 100-fold greater concentration than would normally result from PCR product dispensed in a microtiter well for the MFA caused an overestimation of the calculated DNA concentration of approximately $90 \%$. 


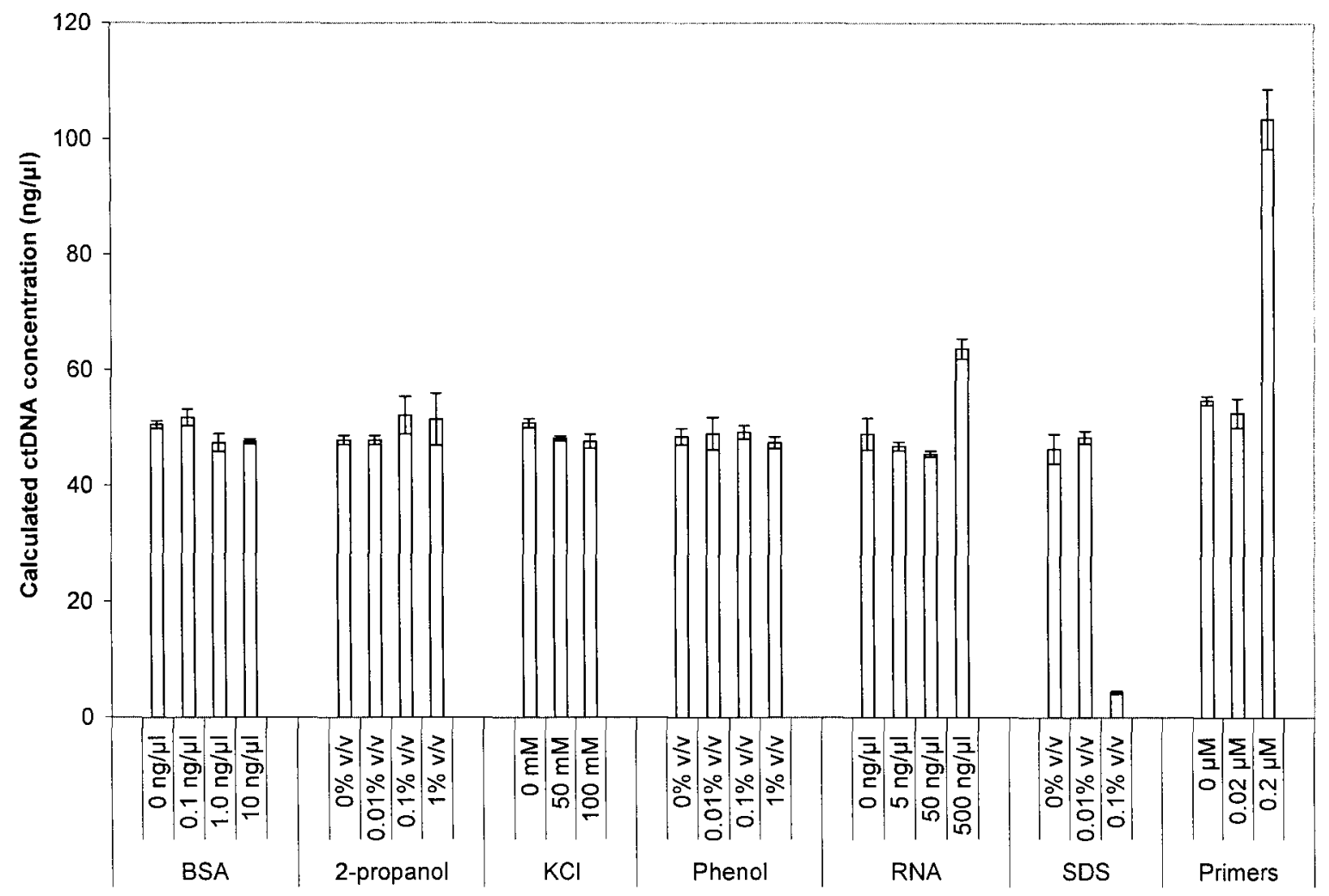

Figure 2.5. Effect of contaminants on DNA quantification. Calf thymus DNA (50 $\mathrm{ng} / \mu \mathrm{l})$ was subjected to the MFA in the presence of different final concentrations of various contaminants. Results are expressed as the mean calculated ctDNA concentration \pm standard deviation $(\mathrm{n}=3)$. 
The levels of contaminant used in these experiments are final concentrations in the assay mixture. Therefore, the level of the contaminants in the starting DNA sample (prior to 100-fold dilution in the assay mixture) would be 100-fold higher than indicated in the figure. Thus, it can be concluded that DNA quantification using the SYBR Green I MFA was not significantly affected by the contaminants tested at concentrations that would commonly be encountered in typical starting DNA preparations.

The SYBR Green I microplate fluorescence assay (MFA) developed herein provided sensitive and accurate quantification of different types of DNA in solution. The assay exhibited superior detectability characteristics compared to spectrophotometry based on ultraviolet absorption and the Hoefer DyNA Quant ${ }^{\circledR} 200$ Fluorometric assay in the quantification of the different types of DNA. The MFA exhibited excellent accuracy and linearity over a broad range of DNA concentrations $(0.25$ to $2500 \mathrm{pg} / \mu \mathrm{l})$. In contrast, the linear range of the PicoGreen $®$ assay (microwell format) was previously shown to be 0.25 to $1000 \mathrm{pg} / \mu \mathrm{l}$ (Singer et al. 1997). When the final SYBR Green I dye concentration was reduced to a 1:10000 dilution to further reduce costs, the linear range of the MFA was 0.5 to $1250 \mathrm{pg} / \mu \mathrm{l}$ (not shown), which is adequate for most molecular biology laboratory applications. The MFA is approximately 5-times less expensive than the PicoGreen ${ }^{\circledR}$ assay when using SYBR Green I at a final concentration of $1: 2500$, and is about 20-times less expensive when using SYBR Green I at a final concentration of $1: 10000$. 
Due to the variety of complex matrices from which DNA can be extracted, very low yields of DNA are frequently encountered in molecular biology applications. Furthermore, depending on the nature of the originating sample and the purification method used, DNA samples can contain impurities present in unknown amounts. This underscores the need for assays capable of quantifying low levels of DNA with minimal consumption of the total available sample, and minimal impact of sample impurities on the accurate quantification of DNA. The MFA meets these requirements in a convenient 96-well format permitting high sample throughput capacity. 


\section{Chapter 3}

\section{An internal amplification control system based on primer- dimer formation for PCR product detection by DNA hybridization}

"This chapter has been published in a peer-reviewed scientific journal:

Leggate, J. and B.W. Blais. (2006) J. Food Protection 69:2280-2284." 


\begin{abstract}
The detection of PCR products by DNA hybridization techniques can suffer from inhibition of the amplification process by sample matrix components. A simple internal control system for PCR has been designed that is based on the incorporation of a primer pair with complementary $3^{\prime}$ ends, resulting in the generation of a unique "primer-dimer" detectable by hybridization with a specific capture probe immobilized on polyester cloth as part of an array of amplicon-specific probes. The inclusion of this primer pair did not adversely affect the amplification and subsequent detection of target gene sequences by hybridization with immobilized probes in either single gene amplification or multiplex PCR systems. Failure to amplify target gene sequences due to the presence of inhibitors was mirrored by a failure to amplify the internal control primer-dimer, demonstrating the efficacy of this system in identifying the presence of DNA amplification inhibitors.
\end{abstract}

\title{
INTRODUCTION
}

The polymerase chain reaction (PCR) coupled with DNA array hybridization techniques for detection of amplicons has found many useful applications in the analysis of foods and related agricultural commodities to determine the presence of specific ingredients and microbial contaminants. The development of simple DNA array hybridization methods have been previously reported that are based on the use of a macroporous, hydrophobic polyester cloth as a solid support for the detection and characterization of multiplex PCR products by hybridization with immobilized DNA probes (Blais et al., 2002). In this cloth-based hybridization array system (CHAS) amplicons incorporating digoxigenin-labeled dUTP are detected by hybridization with an array of specific 
oligonucleotide probes immobilized in discrete spots on a polyester cloth strip, followed by sequential reactions of the strip with anti-digoxigenin antibody-peroxidase conjugate and chromogenic substrate solution. CHAS methods have been developed for the detection and identification of transgenes in genetically modified crops (Blais et al., 2002), multiple antibiotic resistance genes in Salmonella typhimurium DT104 isolates from foods (Gauthier and Blais, 2004), Clostridium botulinum neurotoxin genes (Gauthier et al., 2005), and remnants of prohibited animal species in feedstuffs (Armour and Blais, 2006).

One problem encountered in the application of PCR analysis to complex sample matrices such as foods is interference with the amplification process by inhibitors introduced in the reaction with the target DNA (Rossen et al., 1992). Many quality assurance schemes require that the presence of inhibitors be ruled out by incorporation of an internal amplification control in the PCR system. For this purpose, special DNA preparations have been devised for addition to the PCR mixture or test sample, along with the corresponding primers, in order to control for the presence of inhibitors on the basis of amplification (Sachadyn and Kur, 1998; Jones et al., 2000; Abdulmawjood et al., 2002; Delcenserie et al., 2005). Many amplification control systems have been designed to permit the coamplification of the control DNA with the target DNA using the target DNA-specific primer set (Sachadyn and Kur, 1998; Jones et al., 2000; Abdulmawjood et al., 2002; Delcenserie et al., 2005). Sachadyn and Kur (1998) described an amplification control system based on the use of chimerical primers containing both sample target DNA- and pUC19 plasmid DNA-specific sequences to create a PCR-generated 
amplification control DNA fragment containing target DNA primer binding regions flanking plasmid DNA. Other methods using chimerical primers for the construction of synthetic DNA amplification control fragments have been described for use in the detection of congenital cytomegalovirus infection (Jones et al., 2000) and bifidobacteria in raw milk (Delcenserie et al., 2005). Abdulmawjood et al. (2002) described an alternative method for the construction of an amplification control for the detection of Escherichia coli $\mathrm{O} 157$ by $\mathrm{PCR}$. This approach involved restriction endonuclease digestion of the sample target PCR amplicon to produce three smaller fragments, two of which were ligated together to generate a smaller product (Abdulmawjood et al., 2002). This smaller fragment was then cloned into a plasmid vector which was used as a template for the generation of PCR amplicons serving as a source of amplification control DNA added to PCR mixtures. However, these amplification control DNA preparations are complex, costly, and time-consuming to prepare.

The development of an exquisitely simple internal amplification control (IAC) system based on the incorporation of oligonucleotide primers with complementary $3^{\prime}$ ends in the PCR mixture is described in this chapter. During PCR, these primers should anneal and form a small "primer-dimer"-like product (Fig. 3.1). This product can be detected in a CHAS assay format by hybridization with one of the IAC primers immobilized on polyester cloth serving as a capture probe for the IAC amplicon. As an example, the performance of the IAC system was examined in the context of DNA amplification from transgenic soy and corn. 
IAC-1 5'-CATAATATCACTCGCGTCCGTTGAAGCTTA-3'

IAC-2 5'-GACGAAATCGTAAGCTTCAA-3'

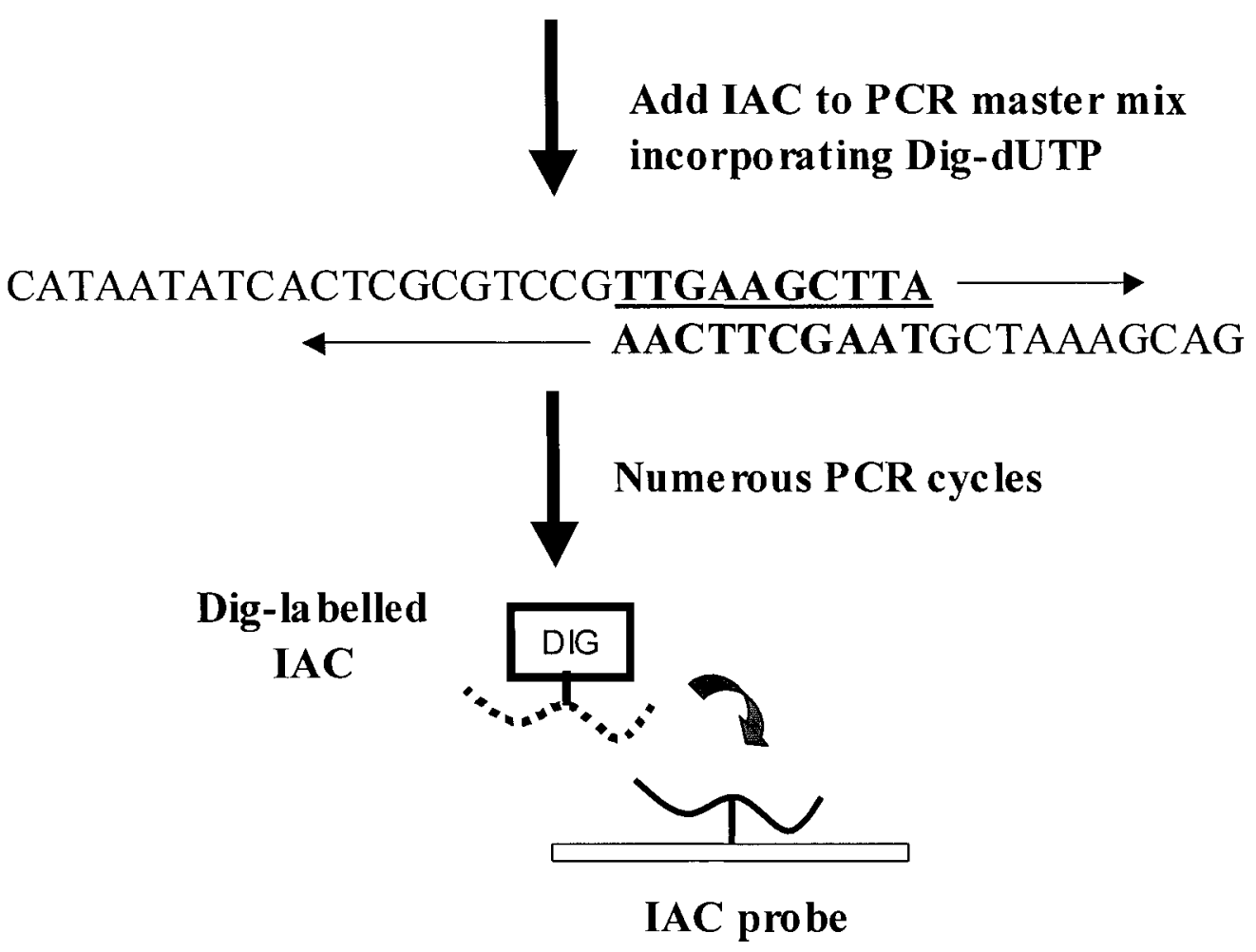

Figure 3.1. Schematic representation of the internal amplification control (IAC) concept 


\section{MATERIALS AND METHODS}

Internal Amplification Control (IAC) Primer Design. Oligonucleotide sequences serving as the IAC primers were generated using a random sequence generator program from the Laboratory for Biocomputing and Informatics site (http://tandem.bu.edu/rsg.html). The oligonucleotides were designed to contain a 10-base region of complementarity at their 3'-ends (Table 3.1) to enable their annealing, resulting in the generation of a 40 bp product during the PCR process. These oligonucleotide sequences had no significant homology to any sequences in the GenBank database, as determined by BLAST analysis. 
Table 3.1. Oligonucleotide primer and probe sequences for PCR-DNA hybridization procedure

Oligonucleotide

Sequence $\left(5^{\prime} \rightarrow 3^{\prime}\right)^{a}$

PCR primers

Lectin-1

AACCGGTAGCGTTGCCAG (NCBI, K00821)

Lectin-2

TTGGTGGATCCCAAGAGT (NCBI, K00821)

IAC-1

CATAATATCACTCGCGTCCGTTGAAGCTTA

IAC-2

GACGAAATCGTAAGCTTCAA

Oligonucleotide probes

Lectin probe

CGCCGCTTCCTTCAACTTCACCTTCTATGCCCCTG-

ACACA

IAC probe

Same as IAC-1

${ }^{a}$ Complementary regions in the IAC primers are underscored. GenBank accession numbers for the lectin primers are indicated in parentheses. 
Template DNA. Transgenic soy (Roundup Ready, variety S14M7RR) and corn (Bt176, variety 36Y96) seeds were used for the preparation of template DNA as previously described (Blais et al., 2002). The genetic characteristics of these materials were as previously described (Blais et al., 2002) and can be summarized as follows: Roundup Ready soy (35S CaMV promoter, NOS terminator and lectin), Bt 176 corn (35S CaMV promoter and invertase).

Soy lectin PCR-cloth hybridization procedure. Test sample $(10 \mu \mathrm{L})$ was added to $40 \mu \mathrm{L}$ of PCR mixture containing 1.25 units of HotStar Taq polymerase and $1 \mathrm{X}$ PCR buffer containing $1.5 \mathrm{mM} \mathrm{MgCl}$ (Qiagen Inc., Mississauga, Ontario), plus $200 \mu \mathrm{M}$ of each dNTP (Promega Corporation, Madison, WI), $10 \mu \mathrm{M}$ DIG-11-dUTP (Roche Diagnostics, Laval, Quebec), $0.04 \mu \mathrm{M}$ each of IAC-1 and IAC-2 and $0.2 \mu \mathrm{M}$ each of Lectin-1 and Lectin-2 (Table 3.1). Unless otherwise stated, the PCR was performed using a Mastercycler gradient thermal cycler (Eppendorf, Westbury, NY) using the following program: initial heating at $94^{\circ} \mathrm{C}$ for $15.5 \mathrm{~min}$, followed by 35 cycles of denaturation at $94^{\circ} \mathrm{C}$ for $30 \mathrm{~s}$, primer annealing at $55^{\circ} \mathrm{C}$ for $30 \mathrm{~s}$, and primer extension at $72^{\circ} \mathrm{C}$ for $30 \mathrm{~s}$, with an additional $3 \mathrm{~min}$ at $72^{\circ} \mathrm{C}$ following the last cycle. Amplicons were analyzed by electrophoresing $10 \mu \mathrm{L}$ of PCR product through a $2 \%(\mathrm{w} / \mathrm{v})$ agarose gel followed by staining with SYBR Green I and visualization under ultraviolet light. A Generuler 50 bp DNA ladder (Fermentas, Burlington, Ontario) was included in each gel.

For the cloth hybridization procedure, polyester cloth (DuPont, Sontara 8100) was cut into 1 X $3 \mathrm{~cm}$ strips, washed with $95 \%(\mathrm{v} / \mathrm{v})$ ethanol followed by rinsing with 
deionized distilled water on a filter with vacuum suction and left to air dry overnight at room temperature. The IAC and lectin capture probes were separately diluted to $17.5 \mu \mathrm{M}$ in high salt buffer (HSB) [0.1 M Tris/ $\mathrm{HCl}(\mathrm{pH} 8), 0.01 \mathrm{M} \mathrm{MgCl}_{2}$ and $\left.0.15 \mathrm{M} \mathrm{NaCl}\right]$, then heated for $10 \mathrm{~min}$ at $100^{\circ} \mathrm{C}$ and placed on ice. The probe solutions were mixed with 0.75 volume of $70 \%(\mathrm{v} / \mathrm{v})$ ethanol to give final coating solutions containing $10 \mu \mathrm{M}$ of probe in HSB with $30 \%(\mathrm{v} / \mathrm{v})$ ethanol. The IAC and lectin probe coating solutions $(5 \mu \mathrm{L})$ were applied in discrete spots at ca. $1 \mathrm{~cm}$ intervals on the cloth strips and incubated at $37^{\circ} \mathrm{C}$ for 30 min. The DNA was cross-linked to the cloth by a 1 min exposure to UV light (254 $\mathrm{nm}, 100 \mathrm{~mJ} / \mathrm{cm}^{2}$ ) using a UVP cross-linker (Model CL-1000, VWR International Inc., Mount Royal, Quebec). The strips were pre-hybridized for at least $1 \mathrm{~h}$ at $37^{\circ} \mathrm{C}$ with hybridization solution $[5 \times \mathrm{SSC}(1 \times \mathrm{SSC}$ is $0.15 \mathrm{M} \mathrm{NaCl}$ plus $0.015 \mathrm{M}$ sodium citrate), $0.02 \%(\mathrm{w} / \mathrm{v})$ SDS, $0.1 \%(\mathrm{w} / \mathrm{v}) \mathrm{N}$-lauroyl sarcosine, $1 \%(\mathrm{w} / \mathrm{v})$ protein blocking reagent (Bio-Rad Laboratories, Hercules, CA)], followed by washing with about $5 \times 30 \mathrm{~mL}$ volumes of $0.01 \mathrm{M}$ phosphate buffered saline $[\mathrm{pH} 7.3,0.85 \%(\mathrm{w} / \mathrm{v}) \mathrm{NaCl}$ ] containing $0.05 \%(\mathrm{v} / \mathrm{v})$ Tween $20(\mathrm{PBST})$ on a filter under suction.

For the assay, DIG-labelled PCR products were denatured by heating at $100^{\circ} \mathrm{C}$ for 10 min and placed on ice. This product $(40 \mu \mathrm{L})$ was mixed with $460 \mu \mathrm{L}$ of ice-cold hybridization solution containing $50 \%(\mathrm{v} / \mathrm{v})$ formamide. The mixture was pipetted onto the probe-coated strip and incubated for $20 \mathrm{~min}$ at $45^{\circ} \mathrm{C}$, followed by washing with PBST as before. The strip was saturated with $1 \mathrm{~mL}$ of anti-DIG-peroxidase conjugate (Roche Diagnostics) diluted 1:2000 in PBST containing 0.5\%(w/v) protein blocking reagent and incubated for $10 \mathrm{~min}$ at room temperature, followed by washing with PBST. The strip 
was saturated with $1 \mathrm{~mL}$ of tetramethylbenzidine (TMB) membrane peroxidase substrate solution (Kirkegaard and Perry Laboratories, Gaithersburg, MD) and incubated for 10 min at room temperature. Reactions at each probe feature on the strip were graded qualitatively as positive (blue spot) or negative (no spot).

Transgenic soy and corn multiplex PCR -CHAS procedure. A multiplex PCR system simultaneously amplifying the crop-specific soy lectin and corn invertase marker genes, as well as transgenic $35 \mathrm{~S} \mathrm{CaMV}$ promoter and NOS terminator sequences, was used in the amplification of $10 \mathrm{ng}$ purified genomic DNA from Roundup Ready soy and Bt176 corn as previously described (Blais et al., 2002), with the exception that the reaction mixture also contained $0.04 \mu \mathrm{M}$ each of IAC-1 and IAC-2 (Table 3.1). The amplicons were then detected in a CHAS procedure involving hybridization with a strip of polyester cloth bearing an array of immobilized amplicon-specific DNA probes (Blais et al., 2002) as well as an additional probe feature corresponding to the IAC probe.

\section{RESULTS AND DISCUSSION}

The internal amplification control (IAC) proposed herein is a template-independent system based on the annealing of two oligonucleotides with complementary $3^{\prime}$ ends (Table 3.1) and formation of a small (40 bp) double-stranded product during PCR. Such an IAC PCR product should be detectable by hybridization with an immobilized capture probe (for example, in a reverse dot blot technique using capture probes immobilized on 
polyester cloth for detection of PCR products) or by agarose gel electrophoresis (AGE) analysis. The amplification and detection of the IAC product was demonstrated using a PCR system targeting the soy lectin gene, in which amplification was carried out in the absence or presence of the IAC primers, with subsequent detection of the digoxigeninlabelled products by hybridization with a strip containing lectin and IAC capture probes and by AGE (Fig. 3.2). Reactions with the lectin and IAC probes on the cloth strip occurred only when amplification was carried out in the presence of either IAC or soy genomic DNA, or both, respectively. The products of the soy lectin and IAC amplification reactions could also be visualized by AGE. 

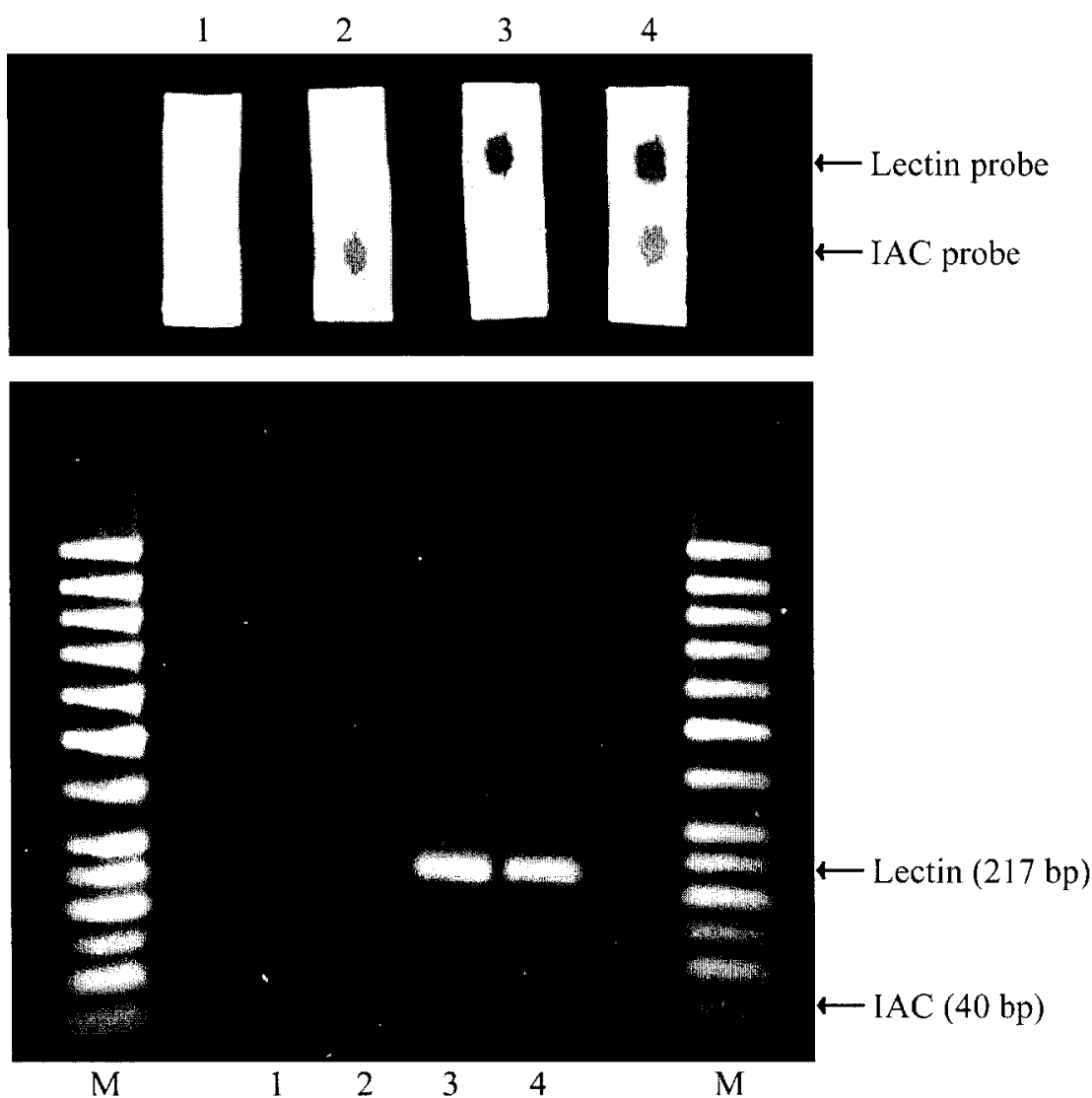

Figure 3.2. Detection of PCR products by soy lectin PCR-cloth hybridization and agarose gel electrophoresis. Soy genomic DNA (0 or $1 \mathrm{ng}$ ) was subjected to the soy lectin PCR procedure ( 0 or $0.04 \mu \mathrm{M}$ IAC primers) and the products analysed by the cloth hybridization procedure (top panel) or agarose gel electrophoresis (bottom panel). For the cloth hybridization procedure, the positions of the lectin and IAC capture probes on the cloth strips are indicated. Samples/lanes: $1,0 \mathrm{ng}$ soy genomic DNA and $0 \mu \mathrm{M}$ IAC primers; 2, 0 ng soy genomic DNA and $0.04 \mu \mathrm{M}$ IAC primers; 3, 1 ng soy genomic DNA and $0 \mu \mathrm{M}$ IAC primers; 4,1 ng soy genomic DNA and $0.04 \mu \mathrm{M}$ IAC primers; $\mathrm{M}, 50 \mathrm{bp}$ DNA molecular size ladder. 
Effect of IAC on target gene amplification by PCR. The IAC primer concentration $(0.04 \mu \mathrm{M})$ used in these experiments was based on the empirically determined minimum quantity yielding a visible spot in the PCR-cloth hybridization procedure (not shown). This was intended to be substantially lower than the typical concentration of target gene-specific primers $(0.2 \mu \mathrm{M})$ used in PCR in order to minimize the impact of the IAC on the amplification of sample DNA. To verify this assumption, different amounts of soy genomic DNA were subjected to the soy lectin PCR in the absence or presence the IAC primers, followed by detection of the PCR products using the cloth hybridization procedure. The detectability of the PCR-cloth hybridization procedure for the soy lectin gene was not affected by the co-amplification of the IAC product, since a minimum of ca.1-10 pg of soy genomic DNA produced a positive signal with the lectin probe in PCR amplifications incorporating the IAC, and a minimum of 10 pg soy genomic DNA produced a positive signal with the lectin probe in PCR amplifications devoid of the IAC (Table 3.2). IAC amplification occurred at all sample DNA concentrations tested, and was not affected by the presence of even a large (100 ng) quantity of DNA. 
Table 3.2. Effect of IAC primers on detectability of the soy lectin PCR-cloth hybridization procedure ${ }^{a}$

\section{Reactivity}

No. Pos. / Total ${ }^{b}$

\begin{tabular}{lcccc} 
Soy DNA & \multicolumn{2}{c}{ IAC probe } & \multicolumn{2}{c}{ Lectin probe } \\
(pg per reaction) & $\mathbf{0 . 0 0} \boldsymbol{\mu M}$ & $\mathbf{0 . 0 4} \boldsymbol{\mu M}$ & $\mathbf{0 . 0 0} \boldsymbol{\mu M}$ & $\mathbf{0 . 0 4} \boldsymbol{\mu M}$ \\
& IAC primers & IAC primers & IAC primers & IAC primers \\
\hline 0 & $0 / 2$ & $2 / 2$ & $0 / 2$ & $0 / 2$ \\
1 & $0 / 2$ & $2 / 2$ & $0 / 2$ & $1 / 2$ \\
10 & $0 / 2$ & $2 / 2$ & $2 / 2$ & $2 / 2$ \\
100 & $0 / 2$ & $2 / 2$ & $2 / 2$ & $2 / 2$ \\
1000 & $0 / 2$ & $2 / 2$ & $2 / 2$ & $2 / 2$ \\
10000 & $0 / 2$ & $2 / 2$ & $2 / 2$ & $2 / 2$ \\
100000 & $0 / 2$ & $2 / 2$ & $2 / 2$ & $2 / 2$
\end{tabular}

${ }^{a}$ Different quantities of soy genomic DNA were subjected to the soy lectin PCR-cloth hybridization procedure using PCR mixtures containing 0.00 or $0.04 \mu \mathrm{M}$ IAC primers. The results are expressed in terms of reactivity of the PCR products with the IAC and lectin capture probes on the cloth strips.

${ }^{b}$ Number of positives per total number of replicates tested. 
Effect of PCR conditions on the IAC. To be generally applicable as a control for PCR, the IAC will need to exhibit efficient amplification over a broad range of PCR conditions, such as annealing temperature and magnesium chloride concentration, which are normally tailored for individual sample target genes. The amplification of the IAC product in the soy lectin PCR was examined using a range of annealing temperatures and magnesium chloride concentrations, with subsequent PCR product detection by the cloth hybridization procedure. Amplification of the IAC product occurred at all of the annealing temperatures (Table 3.3) and magnesium chloride concentrations (Table 3.4) tested, demonstrating the robustness of this system over a range of PCR conditions. The lectin gene PCR product was also detected under these conditions. 
Table 3.3. Effect of annealing temperature on the soy lectin PCR-cloth hybridization procedure $^{a}$

\section{Reactivity}

No. Pos. / Total ${ }^{b}$

\begin{tabular}{lcccc} 
Annealing & \multicolumn{2}{c}{ IAC probe } & \multicolumn{2}{c}{ Lectin probe } \\
Temperature $\left({ }^{\circ} \mathbf{C}\right)$ & $\mathbf{0 ~ n g}$ & $\mathbf{1 0} \mathbf{~ n g}$ & $\mathbf{0} \mathbf{n g}$ & $\mathbf{1 0} \mathbf{~ n g}$ \\
& Soy template & Soy template & Soy template & Soy template \\
\hline 50.1 & $2 / 2$ & $2 / 2$ & $0 / 2$ & $2 / 2$ \\
52.6 & $2 / 2$ & $2 / 2$ & $0 / 2$ & $2 / 2$ \\
55.7 & $2 / 2$ & $2 / 2$ & $0 / 2$ & $2 / 2$ \\
57.3 & $2 / 2$ & $2 / 2$ & $0 / 2$ & $2 / 2$ \\
58.9 & $2 / 2$ & $2 / 2$ & $0 / 2$ & $2 / 2$ \\
60.3 & $2 / 2$ & $2 / 2$ & $0 / 2$ & $2 / 2$ \\
62.2 & $2 / 2$ & $2 / 2$ & $0 / 2$ & $2 / 2$ \\
\hline
\end{tabular}

${ }^{a}$ Samples containing 0 or 10 ng of soy genomic DNA were subjected to the soy lectin PCR-cloth hybridization procedure (with PCR mixtures containing $0.04 \mu \mathrm{M}$ IAC primers) using cycling protocols with different annealing temperatures. The results are expressed in terms of reactivity of the PCR products with the IAC and lectin capture probes on the cloth strips.

${ }^{b}$ Number of positives per total number of replicates tested. 
Table 3.4. Effect of magnesium chloride on the soy lectin PCR-cloth hybridization procedure $^{a}$

\section{Reactivity}

$\mathrm{MgCl}_{2}$

No. Pos. / Total ${ }^{b}$

Concentration

IAC probe

Lectin probe

$(\mathbf{m M})$

0 ng

$10 \mathrm{ng}$

0 ng

$10 \mathrm{ng}$

\section{Soy template Soy template Soy template Soy template}

\begin{tabular}{lllll}
\hline 1.5 & $2 / 2$ & $2 / 2$ & $0 / 2$ & $2 / 2$ \\
2.0 & $2 / 2$ & $2 / 2$ & $0 / 2$ & $2 / 2$ \\
2.5 & $2 / 2$ & $2 / 2$ & $0 / 2$ & $2 / 2$ \\
3.0 & $2 / 2$ & $2 / 2$ & $0 / 2$ & $2 / 2$ \\
3.5 & $2 / 2$ & $2 / 2$ & $0 / 2$ & $2 / 2$ \\
4.0 & $2 / 2$ & $2 / 2$ & $0 / 2$ & $2 / 2$ \\
4.5 & $2 / 2$ & $2 / 2$ & $0 / 2$ & $2 / 2$ \\
\hline
\end{tabular}

${ }^{a}$ Samples containing 0 or $10 \mathrm{ng}$ of soy genomic DNA were subjected to the soy lectin PCR-cloth hybridization procedure with PCR mixtures containing $0.04 \mu \mathrm{M}$ IAC primers and different concentrations of magnesium chloride. The results are expressed in terms of reactivity of the PCR products with the IAC and lectin capture probes on the cloth strips.

${ }^{b}$ Number of positives per total number of replicates tested. 
Effect of sample condition on the IAC. The effect of various known PCR inhibitors (Rossen et al., 1992), such as isopropanol, phenol, SDS and EDTA, on the amplification of the IAC product and the soy lectin gene using a minimal amount of soy template DNA was examined. All of the inhibitors tested resulted in failure to detect both the IAC and soy lectin gene PCR products regardless of the absence or presence of soy genomic DNA, whereas PCR mixtures devoid of inhibitors gave the expected pattern of IAC and soy lectin product reactivity (Table 3.5). These results demonstrate the effectiveness of the IAC in identifying the presence of PCR inhibitors, since the IAC only produced a signal when the PCR was uninhibited.

The effect of the integrity of the sample DNA was verified by heating $0.1 \mathrm{ng}$ of soy genomic DNA at $100^{\circ} \mathrm{C}$ for $20 \mathrm{~min}$, which was expected to partially degrade the DNA, and then subjecting the heat-treated DNA preparation to the soy lectin PCR-cloth hybridization procedure. The heat treatment resulted in a failure to detect the soy lectin PCR product by cloth hybridization, while the IAC product remained detectable (not shown). Thus, while the IAC was an effective control for PCR failure due to the presence of inhibitors, it was unable to indicate lack of amplifiability of sample DNA due to degradation. 
Table 3.5. Effect of inhibitors on the soy lectin PCR-cloth hybridization procedure ${ }^{a}$

\begin{tabular}{|c|c|c|c|c|}
\hline \multirow{5}{*}{ PCR Inhibitor } & \multicolumn{4}{|c|}{ Reactivity } \\
\hline & \multicolumn{4}{|c|}{ No. Pos. / Total ${ }^{b}$} \\
\hline & \multicolumn{2}{|c|}{ IAC probe } & \multicolumn{2}{|c|}{ Lectin probe } \\
\hline & $0 \mathrm{ng}$ & $0.1 \mathrm{ng}$ & O ng & $0.1 \mathrm{ng}$ \\
\hline & Soy template & Soy template & Soy template & Soy template \\
\hline None & $2 / 2$ & $2 / 2$ & $0 / 2$ & $2 / 2$ \\
\hline $6.0 \%$ Isopropanol & $0 / 2$ & $0 / 2$ & $0 / 2$ & $0 / 2$ \\
\hline $1 \%$ phenol & $0 / 2$ & $0 / 2$ & $0 / 2$ & $0 / 2$ \\
\hline $0.01 \%$ SDS & $0 / 2$ & $0 / 2$ & $0 / 2$ & $0 / 2$ \\
\hline 1 mM EDTA & $0 / 2$ & $0 / 2$ & $0 / 2$ & $0 / 2$ \\
\hline
\end{tabular}

${ }^{a}$ Samples containing 0 or $0.1 \mathrm{ng}$ of soy genomic DNA were subjected to the soy lectin PCR-cloth hybridization procedure with PCR mixtures containing $0.04 \mu \mathrm{M}$ IAC primers and different inhibitors (final concentrations in the PCR mixtures indicated). The results are expressed in terms of reactivity of the PCR products with the IAC and lectin capture probes on the cloth strips.

\footnotetext{
${ }^{b}$ Number of positives per total number of replicates.
} 
Application of the IAC in a multiplex PCR-CHAS format. The preceding examples demonstrate the effectiveness of the IAC in the context of a single target gene detection system. Ideally, the IAC should display good performance characteristics in more complex amplification systems, such as multiplex PCR where several gene targets are amplified simultaneously with the attendant possibility of complex, imponderable effects on the efficiency of the IAC. Therefore, the performance of the IAC was examined in the context of a multiplex PCR-CHAS approach designed for the simultaneous amplification of multiple genes in transgenic soy and corn (Blais et al., 2002). In this system, products from a PCR incorporating multiple target gene-specific and IAC primers were detected by hybridization with an array of immobilized ampliconspecific capture probes including the IAC probe. The performance of the IAC was examined using different combinations of transgenic soy and corn genomic DNA subjected to the multiplex PCR-CHAS procedure. The IAC product was detected with equal reaction intensity in all combinations of sample DNA tested (Fig. 3.3). The expected patterns of reactivity were obtained in the multiplex PCR-CHAS for the various combinations of sample target genes introduced into the PCR, and were unaffected by the IAC. 


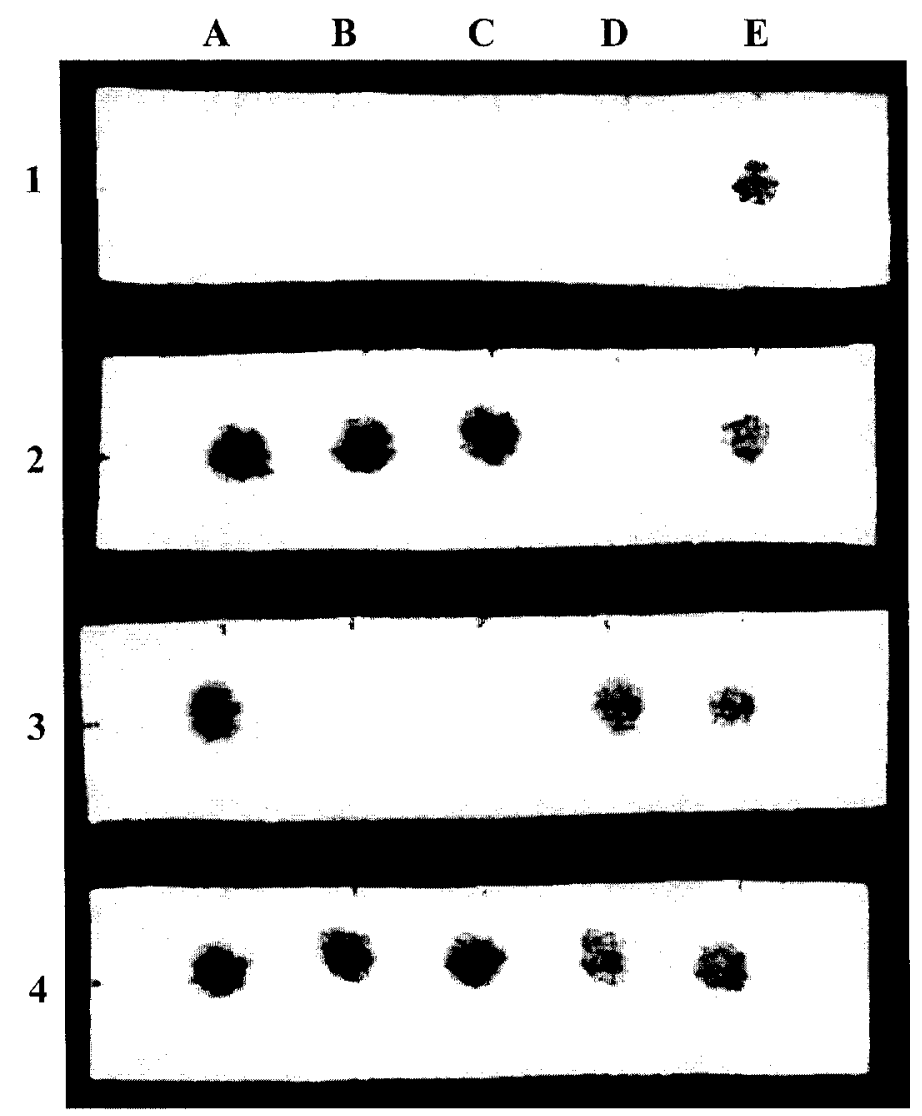

Figure 3.3. Detection of transgenic corn and soy in a Multiplex PCR-CHAS incorporating the IAC sequences. Different combinations of genomic DNA (10 ng each) from Roundup Ready soy and Bt176 corn were subjected to the transgenic soy and corn multiplex PCR-CHAS procedure. Probes on the array were as follows: A, CaMV 35S promoter; B, soy lectin; C, NOS terminator; D, corn invertase; E, IAC. Combinations of genomic DNA were as follows: 1, no template DNA; 2, $10 \mathrm{ng}$ RR soy; 3, $10 \mathrm{ng}$ Bt176 corn; 4, 10 ng each of RR soy and Bt176 corn. 
These studies demonstrate the feasibility of utilizing a simple templateindependent internal amplification control for the presence of amplification inhibitors under a variety of PCR conditions. Previously described procedures for constructing template DNA serving as amplification controls are relatively complex and labourintensive (Sachadyn and Kur, 1998; Jones et al., 2000; Abdulmawjood et al., 2002; Delcenserie et al., 2005). Furthermore, these approaches require the creation of a specific amplification control DNA fragment for each analytical target. The present IAC system did not require the preparation of specialized templates, which would add to the cost and complexity of the assay, and utilized a simple primer pair which were readily incorporated in the PCR master mix. The present system exploits a purposely designed "primer-dimer" in which the originating primer concentration are minimized in the PCR mixture in order to avoid the possible depletion of reaction components, which might otherwise adversely affect the amplification of sample target genes. The amplification of the IAC product did not impact negatively on the simultaneous detection of target genes in either single target or multiplex PCR systems.

The present studies focused on the detection of PCR products by hybridization with capture probes immobilized on polyester cloth; however, it should be possible to extend the principle of the present IAC to other assay formats, including membrane hybridization and microarray systems. Furthermore, it was possible to visualize the IAC products by agarose gel electrophoresis analysis, making this system amenable to more conventional PCR approaches. Further experiments need to be performed to ascertain the 
performance of the IAC system in the analysis of real world samples containing PCR inhibitors. The present IAC system offers a simple means of avoiding reporting false negative results due the presence of sample inhibitors in the PCR, and provides an effective tool for incorporation in laboratory quality assurance schemes.

Addendum. More recent studies have shown that replacement of the IAC-1 capture probe sequence (Table 3.1) with the following probe sequence resulted in a stronger reaction intensity for the IAC spot on the array:

5'- CATAATATCACTCGCGTCCGTTGAAGCTTACGATTTCGTC - 3’ 


\section{Chapter 4}

Cloth-based hybridization array system for detection of

multiple plant crops by multiplex polymerase chain reaction 


\section{ABSTRACT}

A cloth-based hybridization array system (CHAS) was developed for the determination of crop ingredients in foods on the basis of detection of amplicons generated in a multiplex PCR targeting specific endogenous gene sequences in corn (Zea mays), soy (Glycine max), rice (Oryza sativa), wheat (Triticum aestivum), and potato (Solanum tuberosum). In addition, amplification efficiency was monitored by the inclusion of an internal amplification control (IAC) in the reaction mix. Amplicons were detectable by hybridization with specific capture probes immobilized on polyester cloth, which enabled discrimination of the multiplex PCR products and confirmed PCR amplification efficiency by visualization of the amplicons on the array. The specificity of the CHAS was verified by subjecting purified genomic DNA from a panel of target and non-target crops to the combined multiplex-PCR CHAS procedure. No cross-reactivities were observed for the majority of the non-target templates, apart from a weak-positive reaction from barley (Hordeum vulgare), which cross-reacted with the wheat-specific capture probe. The detectability of the assay for purified genomic DNA from the five different crops varied from $10 \mathrm{pg}$ to $100 \mathrm{pg}$, and was $0.01 \%(\mathrm{w} / \mathrm{w})$ and $0.5 \%(\mathrm{w} / \mathrm{w})$ for the soy and corn flours (respectively) blended in an oatmeal flour matrix. The applicability of the CHAS was verified by subjecting purified genomic DNA from a variety of retail food products to the combined multiplex-PCR and CHAS procedure. The crop CHAS failed to detect target sequences from most of the processed food samples, demonstrating the difficulties associated with the identification of ingredients in highly processed foodstuffs, and the importance of verifying the amplifiability of DNA prior to subjecting the sample to further testing for specific transgenic sequences. 


\section{INTRODUCTION}

The introduction of plant crops with novel traits into the food supply has resulted in many countries establishing testing programs for the detection of genetically modified (GM) ingredients in foods due to consumer concerns relating to foods produced by recombinant DNA techniques. Methods for the detection of GM ingredients in foods usually employ nucleic acid amplification-based techniques to screen samples for genetic material common to many GM crops (e.g. CaMV35S promoter or NOS terminator sequences), followed by further analyses for specific GM events (Hardegger et al., 1999; Lipp et al., 1999; Blais et al., 2002).

As the number of transgenic elements being introduced into different plant crops continues to increase, the traditional approach of applying target-specific PCR methods will become increasingly impractical. In a mixed food sample containing numerous crop ingredients, the number of different possible transgenic elements to test for can become rather cumbersome. Therefore, there is a need to minimize the number of choices of individual tests which must be carried out to make testing foods for transgenic elements more practical. A tiered approach is needed wherein a limited number of key tests are conducted on a food sample to determine, first, which explicit ingredients are present, followed by further testing for the known transgenic elements that are relevant to the different crops identified. 
The development of simple DNA array hybridization methods have been described that are based on the use of a macroporous, hydrophobic polyester cloth as a solid support for the detection and characterization of multiplex PCR products by hybridization with immobilized DNA probes (Blais et al., 2002). The advantages of polyester cloth for use as a solid matrix in DNA hybridization arrays have been previously described (Blais and Phillippe, 1995). In this cloth-based hybridization array system (CHAS), amplicons incorporating digoxigenin-labeled dUTP are detected by hybridization with an array of specific oligonucleotide probes immobilized in discrete spots on a polyester cloth strip, followed by sequential reactions of the strip with antidigoxigenin antibody-peroxidase conjugate and chromogenic substrate solution. CHAS methods have been developed for the detection and identification of transgenic sequences in genetically modified crops (Blais et al., 2002), multiple antibiotic resistance genes in Salmonella typhimurium DT104 isolates from foods (Gauthier and Blais, 2004), Clostridium botulinum neurotoxin genes (Gauthier et al., 2005), and remnants of prohibited animal species in feedstuffs (Armour and Blais, 2006).

Rather than targeting a specific GM event or regulatory sequence, a multiplex PCR and cloth-based hybridization array system was developed to detect specific endogenous gene sequences in corn (Zea mays), soy (Glycine max), rice (Oryza sativa), wheat (Triticum aestivum), and potato (Solanum tuberosum) (Fig. 4.1). These crops represent a selection of common food crops for which genetically modified versions have been approved for cultivation in (or import into) Canada, and are therefore the most likely ingredients to harbour transgenic elements in a mixed food sample (AGBIOS, 
2006). In this manner, the assay may be used as a preliminary screening tool to confirm which crops are present in a food sample prior to analyzing the sample for a crop-specific transgenic event, and would also serve as an indicator of the amplifiability of the DNA from specific crop species. Amplification of DNA from highly processed samples (such as foods) is often impeded by the presence of amplification inhibitors that may be copurified with the extracted genomic DNA. Therefore, to avoid false negative reporting caused by PCR failure attributable to the presence of inhibitory substances, a complementary probe sequence specific to a template-independent internal amplification control (IAC) (Leggate and Blais, 2006; Chapter 3, this thesis), was also included in the array. 
Purified genomic DNA from a food sample

Multiplex PCR incorporating Dig-11-dUTP

Hybridization and Immunoenzymatic Detection

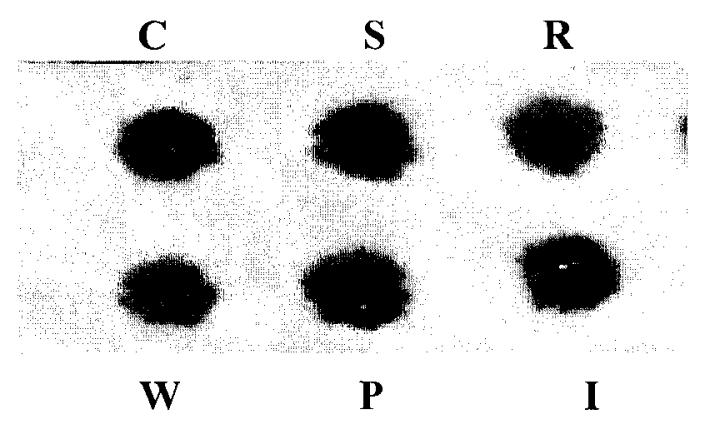

Figure 4.1. Schematic representation of the combined multiplex PCR and CHAS for the determination of crop ingredients in foods. Capture probes: C, corn zein; S, soy lectin; R, rice phospholipase $\mathrm{D} ; \mathrm{W}$, wheat waxy; $\mathrm{P}$, potato sucrose synthase; I, internal amplification control 


\section{MATERIALS AND METHODS}

Template DNA. Purified genomic DNA was extracted from the following plant materials: Transgenic soy seeds (Glycine max, Roundup Ready, variety S14M7RR), transgenic corn seeds (Zea mays, Yieldgard, variety N44P4-Bt), non-GM rice (Oryza sativa, Sunbrown Calrose brown rice, purchased from a local supermarket), common wheat seeds (Triticum aestivum, collected by our laboratory). Transgenic potato DNA (Solanum tuberosum, NewLeaf, Atlantic) was kindly supplied by Donna Smith (CFIA PEI Laboratory). Template DNA was extracted from the following for use in the specificity panel: Seeds from Japanese millet (Echinochloa esculenta), barley (Hordeum vulgare), foxtail millet (Setaria italica), rye (Secale cereale), rice cutgrass (Leersia oryzoides), Sorghum bicolour, pearl millet (Pennisetum glaucum), bamboo (Bambusa vulgaris), and wild rice (Zizania aquatica) were collected by our laboratory. Navy beans (Phaseolus vulgaris), kidney beans (Phaseolus vulgaris), green split peas (Pisum sativum), red lentils (Lens culinaris), chick peas (Cicer arietinum), and lima beans (Phaseolus lunatus) were purchased from a local supermarket as dried samples (Nupak brand). Tomato (Solanum lycopersicum), green pepper (Capsicum annuum), eggplant (Solanum melongena), alfalfa sprouts (Medicago sativa), bean sprouts (Vigna radiata), and green beans (Phaseolus vulgaris) were purchased as fresh samples from a local supermarket. 
For extraction of DNA, samples were blended using a Waring blender. DNA was extracted using 200-300 mg of the blended samples using Wizard Plus Minipreps DNA purification columns and resin (Promega Corporation, Madison, WI) as specified by Lipp et al. (1999). Genomic DNA was quantified using the SYBR Green I microplate fluorescence assay as described by Leggate et al. (2006) and in Chapter 2 of this thesis.

Flour Blends. Quick oats (President's Choice Organics) were purchased from a local retailer to be used as a blank food matrix into which soy and corn flours could be blended to create mixtures containing different levels of target crop materials. Approximately $100 \mathrm{~g}$ of oats were added into two separate $500 \mathrm{~mL}$ Sinterkorund 1 bowls (Fritsch GmbH, Idar-Oberstein, Germany), each containing 3 x $40 \mathrm{~mm}$ grinding balls, and ground into a fine flour using the Fritsch Pulverisette 5 Planetary Mill (Fritsch GmbH, Idar-Oberstein, Germany) set at $200 \mathrm{rpm}$ for $20 \mathrm{~min}$. Blends of soy and corn in oat flour were prepared gravimetrically by mixing certified soy flour (Fluka Biochemika, no. 4712, 5\% RoundUp Ready) and certified corn flour (Fluka Biochemika, no. 0317, 5\% MON 810) into oat flour at varying concentrations $(5 \%, 1 \%, 0.5 \%, 0.1 \%, 0.05 \%, 0.01 \%$ and $0.001 \% \mathrm{w} / \mathrm{w}$ ) as follows. For the $5 \% \mathrm{w} / \mathrm{w}$ mixture, $0.4 \mathrm{~g}$ of soy or corn flour were added to $7.6 \mathrm{~g}$ of oat flour in a $100 \mathrm{~mL}$ screw cap container and mixed in a Turbula Mixer (model T2F, Glen Mills Inc., Clifton, N.J.) for $30 \mathrm{~min}$. Blends comprising lower concentrations of soy or corn were prepared by successive serial dilutions of each of the $5 \%$ blends with oat flour. DNA was extracted from approximately $300 \mathrm{mg}$ of each of the flour blends using the Qiagen DNeasy Plant Maxi kit (Qiagen Inc., Mississauga, Ontario) following the manufacturer's instructions, and quantified as described above. 
Food Samples. Food samples were purchased from a local supermarket for subsequent analysis by the multiplex-PCR Crop CHAS (Table 4.1). All wet samples were mixed by stomaching for $4 \mathrm{~min}$. The dry samples were ground into a fine flour using the Planetary Mill as described above. Approximately $1 \mathrm{~g}$ of each of the wet samples, and $0.5 \mathrm{~g}$ of each of the dry samples, were subjected to DNA extraction using the Qiagen DNeasy Plant Maxi kit (Qiagen Inc., Mississauga, Ontario) following the manufacturer's instructions. As low DNA yields were obtained following extraction using the Qiagen method $(<1 \mathrm{ng} / \mu \mathrm{l}$ for most samples), certain samples were subjected to an additional DNA extraction procedure by grinding in liquid nitrogen followed by DNA extraction using Wizard Plus Minipreps DNA purification columns and resin (Promega) as specified by Lipp et al. (1999), and the DNA quantified as described above. 
Table 4.1. Ingredients for food samples purchased from a local supermarket for subsequent analysis by the combined multiplex-PCR Crop CHAS procedure

\begin{tabular}{|c|c|}
\hline Food Sample & Ingredients $^{a}$ \\
\hline Canned Chicken and Rice Soup & $\begin{array}{l}\text { Carrots, potatoes, waxy and/or green beans, peas, } \\
\text { celery, cabbage, onions, water, salt, calcium chloride } \\
\text { Chicken broth, rice, chicken, salt, carrots, chicken fat, } \\
\text { modified corn starch, celery, monosodium glutamate, } \\
\text { chicken flavour (autolyzed yeast extract, soy, wheat } \\
\text { and corn proteins), onion powder, sugar, spice extract, } \\
\text { colour }\end{array}$ \\
\hline $\begin{array}{l}\text { Garden Vegetable with Whole } \\
\text { Wheat Penne Pasta Dry Soup } \\
\text { Mix }\end{array}$ & $\begin{array}{l}\text { Whole wheat pasta, corn, onions, tomatoes, carrots, } \\
\text { peas, green beans, garlic, corn syrup solids, hydrolyzed } \\
\text { corn/soy/wheat protein, sugar, salt, monosodium } \\
\text { glutamate, autolyzed yeast extract, potato starch, } \\
\text { canola oil, parsley, spices, flavour, colour, silicon } \\
\text { dioxide and sulphites }\end{array}$ \\
\hline $\begin{array}{l}\text { Canned Organics Strained } \\
\text { Sweet Corn Casserole Baby } \\
\text { Food }\end{array}$ & Organic corn, water, organic brown rice flour \\
\hline Dry Fajita Seasoning Mix & $\begin{array}{l}\text { Corn starch, maltodextrin, hydrolyzed corn and soy } \\
\text { protein, sugar, salt, onion and garlic powder, chili } \\
\text { pepper, spice, citric acid, caramel colour, hydrogenated } \\
\text { soybean oil, mesquite smoke flavour, silicon dioxide, } \\
\text { sulphites }\end{array}$ \\
\hline Canned Turkey Gravy & $\begin{array}{l}\text { Turkey broth, enriched wheat flour, modified corn } \\
\text { starch, turkey skins, water, yeast extract, salt, turkey }\end{array}$ \\
\hline
\end{tabular}




\begin{tabular}{l|l}
\hline Garlic \& Vegetable Instant & $\begin{array}{l}\text { fat, chicken fat, flavour, onion powder, spice, caramel, } \\
\text { beta carotene }\end{array}$ \\
Rice Noodle Dry Soup Mix & $\begin{array}{l}\text { Rice, water, tapioca, sugar, salt, spices, maltodextrin, } \\
\text { hydrolyzed corn and soy protein, autolyzed yeast, } \\
\text { sunflower oil, soybean oil, chilli, garlic, shallot, } \\
\text { tocopherol }\end{array}$ \\
Canned Irish Stew & $\begin{array}{l}\text { Water, formed meat (beef and/or mutton, water, salt, } \\
\text { monosodium glutamate), potatoes, carrots, peas, } \\
\text { modified corn starch, sugar, salt, enriched wheat flour, } \\
\text { spices, red bell pepper, caramel colour, seasoning } \\
\text { (contains canola oil) }\end{array}$ \\
Canned Vegetarian Chili & $\begin{array}{l}\text { Water, red, pink and black beans, textured soy flour } \\
\text { (soy flour, caramel colour), tomato paste, onions, } \\
\text { tomatoes (contain citric acid, calcium chloride), } \\
\text { carrots, celery, zucchini, sugar, green bell peppers, } \\
\text { modified corn starch, high oleic sunflower oil, red bell } \\
\text { peppers, spices, salt, garlic }\end{array}$ \\
\hline
\end{tabular}

${ }^{a}$ Ingredients as listed on the product label 
Primer and Probe Design. Primer pairs were chosen to amplify short gene segments $(>300 \mathrm{bp})$ specific to each of the five crops of interests, namely corn, soy, rice, wheat and potato, to generate the following PCR products: $277 \mathrm{bp}$ amplicon from the corn zein gene (Studer et al., 1997; NCBI X07535), 217 bp amplicon from soy lectin (Blais et al., 2002; NCBI K00821), 123 bp from rice phospholipase D (NCBI AB001919), 102 bp from wheat waxy D1 locus (Iida et al., 2005), and a 215 bp amplicon from potato sucrose synthase (Akiyama et al., 2002; NCBI U24087) (Table 4.2). Cropspecific oligonucleotide probes for immobilization on the arrays were designed using DNAMan sequence analysis software (Lynnon BioSoft, Vaudreuil-Dorion, QC, Canada) (Table 4.2). As an indicator of PCR amplification efficiency, a template independent primer pair serving as an internal amplification control was included in the PCR mixture, and its corresponding capture probe immobilized on the array (Leggate and Blais, 2006; Chapter 3 , this thesis). All oligonucleotides were synthesized by a commercial contractor (Alpha DNA, Montreal, Quebec). 
Table 4.2. Oligonucleotide primer and probe sequences for PCR-DNA hybridization procedure

$\begin{array}{lll}\text { Oligonucleotide } & \text { Sequence }\left(5^{\prime} \rightarrow 3^{\prime}\right) & \text { Source }\end{array}$

\begin{tabular}{|c|c|c|}
\hline \multicolumn{3}{|c|}{ PCR primers } \\
\hline Zein-3 & AGTGCGACCCATATTCCAG & NCBI, X07535; \\
\hline Zein-4 & GACATTGTGGCATCATCATTT & Studer et al. (1997) \\
\hline Sltn-1 & AACCGGTAGCGTTGCCAG & NCBI, K00821; \\
\hline Sltn-5 & TTGGTGGATCCCAAGAGT & Blais et al. (2002) \\
\hline RPD-F & CGAAGAGGATCAATGCTGAC & \multirow{2}{*}{ NCBI, AB001919 } \\
\hline RPD-R & TAGCATAGTCTGTGCCATCC & \\
\hline $\mathrm{Wx} 012-5$ & GTCGCGGGAACAGAGGTGT & \multirow[b]{2}{*}{ Iida et al. (2005) } \\
\hline Wx012-3' & GGTGTTCCTCCATTGCGAAA & \\
\hline PSS-F & TGACCTGGACACCACAGTTAT & NCBI, U24087; \\
\hline PSS-R & GTGGATTTCAGGAGTTCTTCGA & $\begin{array}{l}\text { Akiyama et al. } \\
\text { (2002) }\end{array}$ \\
\hline IAC-1 & CATAATATCACTCGCGTCCGTTGAAGCTTA & Leggate and Blais, \\
\hline IAC-2 & GACGAAATCGTAAGCTTCAA & $\begin{array}{l}\text { 2006; Chapter 3, this } \\
\text { thesis }\end{array}$ \\
\hline \multicolumn{3}{|c|}{ Oligonucleotide probes } \\
\hline Zein probe & $\begin{array}{l}\text { CATTGATGATGCCGAGCATGATGTCACCAA } \\
\text { TGGTCTTGCC }\end{array}$ & NCBI, X07535 \\
\hline
\end{tabular}




\begin{tabular}{lll}
\hline \multirow{2}{*}{ Lectin probe } & CGCCGCTTCCTTCAACTTCACCTTCTATGCC & NCBI, K00821; \\
& CCTGACACA & Blais et al. (2002) \\
RPD probe & GTTGAATGGTGAGTATGAACCTGCAGGTCG & NCBI, AB001919 \\
& CCCTTTGGATGGC & \\
PSS probe & CTCAGCCAAAAGCTCGTGAGGTTTCAATAT & NCBI, U24087 \\
& CCCTTTTCCG & \\
Wx012 probe & TGCGGCGGAATCGCCACCCACCGTGAAGTT & Iida et al. (2005) \\
& CAC & Leggate and Blais, \\
& & 2006; Chapter 3, this \\
IAC probe & Same as IAC-1 & thesis
\end{tabular}


Multiplex PCR-cloth hybridization procedure. Samples were subjected to a multiplex PCR incorporating five primer pairs targeting corn zein, soy lectin, rice phospholipase D (RPD), wheat waxy (Wx012), potato sucrose synthase (PSS) sequences, as well as an internal amplification control (IAC) (Table 4.2). For the PCR, test sample $(10 \mu \mathrm{L})$ was added to $40 \mu \mathrm{L}$ of PCR mixture containing 1.25 units of HotStar Taq polymerase and $1 \mathrm{X}$ PCR buffer containing $1.5 \mathrm{mM} \mathrm{MgCl}_{2}$ (Qiagen Inc., Mississauga, Ontario), plus an additional $0.5 \mathrm{mM} \mathrm{MgCl}_{2}, 200 \mu \mathrm{M}$ of each dNTP (Promega Corporation, Madison, WI), $10 \mu \mathrm{M}$ DIG-11-dUTP (Roche Diagnostics, Laval, Quebec), $0.2 \mu \mathrm{M}$ each of Zein-3 and Zein-4, $0.4 \mu \mathrm{M}$ each of Sltn-1 and Sltn-5, 0.1 $\mu \mathrm{M}$ each of RPD-F and RPD-R, $0.5 \mu \mathrm{M}$ each of Wx012-5' and Wx012-3', $0.2 \mu \mathrm{M}$ each of PSS-F and PSS-R, and $0.04 \mu \mathrm{M}$ each of IAC-1 and IAC-2 (Table 4.2). Unless otherwise stated, the PCR was performed using a Mastercycler gradient thermal cycler (Eppendorf, Westbury, $\mathrm{NY}$ ) using the following program: initial heating at $94^{\circ} \mathrm{C}$ for $15.5 \mathrm{~min}$, followed by 35 cycles of denaturation at $94^{\circ} \mathrm{C}$ for $30 \mathrm{~s}$, primer annealing at $55^{\circ} \mathrm{C}$ for $30 \mathrm{~s}$, and primer extension at $72^{\circ} \mathrm{C}$ for $30 \mathrm{~s}$, with an additional $3 \mathrm{~min}$ at $72^{\circ} \mathrm{C}$ following the last cycle.

For the cloth hybridization procedure, polyester cloth (DuPont, Sontara 8100) was cut into 2 X $4 \mathrm{~cm}$ strips, washed with $95 \%$ (v/v) ethanol followed by rinsing with deionized distilled water on a filter with vacuum suction and left to air dry overnight at room temperature. The corn zein, soy lectin, rice phospholipase D, wheat waxy, potato sucrose synthase and IAC capture probes were separately diluted to $14.6 \mu \mathrm{M}$ in high salt buffer (HSB) [0.1 M Tris/HCl (pH 8), $0.01 \mathrm{M} \mathrm{MgCl}_{2}$ and $\left.0.15 \mathrm{M} \mathrm{NaCl}\right]$, then heated for $10 \mathrm{~min}$ at $100^{\circ} \mathrm{C}$ and placed on ice. The probe solutions were mixed with 0.46 volume of 
$95 \%(\mathrm{v} / \mathrm{v})$ ethanol to give final coating solutions containing $10 \mu \mathrm{M}$ of probe in HSB with $30 \%(\mathrm{v} / \mathrm{v})$ ethanol. The various probe coating solutions $(5 \mu \mathrm{L})$ were applied in discrete spots at ca. $1 \mathrm{~cm}$ intervals on the cloth strips and incubated at $37^{\circ} \mathrm{C}$ for $30 \mathrm{~min}$. The DNA was cross-linked to the cloth by a 1 min exposure to UV light (254 nm, 100 $\mathrm{mJ} / \mathrm{cm}^{2}$ ) using a UVP cross-linker (Model CL-1000, VWR International Inc., Mount Royal, Quebec). The strips were pre-hybridized for at least $1 \mathrm{~h}$ at $37^{\circ} \mathrm{C}$ with hybridization solution [ $5 \times \mathrm{SSC}(1 \times \mathrm{SSC}$ is $0.15 \mathrm{M} \mathrm{NaCl}$ plus $0.015 \mathrm{M}$ sodium citrate), $0.02 \%(\mathrm{w} / \mathrm{v})$ SDS, $0.1 \%(\mathrm{w} / \mathrm{v})$ N-lauroyl sarcosine, $1 \%(\mathrm{w} / \mathrm{v})$ protein blocking reagent (Bio-Rad Laboratories, Hercules, CA)], followed by washing with about $5 \times 30 \mathrm{~mL}$ volumes of $0.01 \mathrm{M}$ phosphate buffered saline $[\mathrm{pH} 7.3,0.85 \%(\mathrm{w} / \mathrm{v}) \mathrm{NaCl}]$ containing $0.05 \%(\mathrm{v} / \mathrm{v})$ Tween $20(\mathrm{PBST})$ on a filter under suction.

For the assay, DIG-labelled PCR products were denatured by heating at $100^{\circ} \mathrm{C}$ for $10 \mathrm{~min}$ and placed on ice. This product $(40 \mu \mathrm{L})$ was mixed with $960 \mu \mathrm{L}$ of ice-cold hybridization solution containing $50 \%(\mathrm{v} / \mathrm{v})$ formamide. The mixture was pipetted onto the probe-coated strip and incubated for $20 \mathrm{~min}$ at $45^{\circ} \mathrm{C}$, followed by washing with PBST as before. The strip was saturated with $1 \mathrm{~mL}$ of anti-DIG-peroxidase conjugate (Roche Diagnostics) diluted 1:2000 in PBST containing 0.5\%(w/v) protein blocking reagent and incubated for $10 \mathrm{~min}$ at room temperature, followed by washing with PBST. The strip was saturated with $1 \mathrm{~mL}$ of tetramethylbenzidine (TMB) membrane peroxidase substrate solution (Kirkegaard and Perry Laboratories, Gaithersburg, MD) and incubated for 10 min at room temperature. Reactions at each probe feature on the strip were graded qualitatively as positive (blue spot) or negative (no spot). 


\section{RESULTS AND DISCUSSION}

The performance characteristics of the combined multiplex-PCR and cloth-based hybridization array system (CHAS) in the detection of five different crops were examined with different quantities of purified genomic DNA from each of the target plant species. The detectability of the assay for each particular target crop species (e.g. corn) was also examined in the presence of an excess of competing template DNA (50 ng) from a different crop species (e.g. soy). The application of the multiplex-PCR CHAS in the detection of different levels of corn and soy blended in non-target oatmeal flour was also examined.

Limit of Detection. The detectability of the multiplex PCR-CHAS for each of the crop species was examined using different quantities of purified genomic DNA from each of the target plant crops. The assay was capable of detecting a minimum of $10 \mathrm{pg}$ of corn, soy and rice template DNA, and $100 \mathrm{pg}$ of wheat and potato template DNA (Table 4.3). In the presence of an excess of competing template DNA (50 ng of soy genomic DNA when assaying the detectability of corn, rice, wheat and potato; or $50 \mathrm{ng}$ of corn genomic DNA when assaying the detectability of soy), the limit of detection increased about 5-fold for the corn, rice and wheat targets, and remained unchanged for the soy and potato targets (Table 4.3). 
Table 4.3. Detectability of multiplex PCR-CHAS in the assay of different amounts genomic DNA from each of the target crops ${ }^{a}$

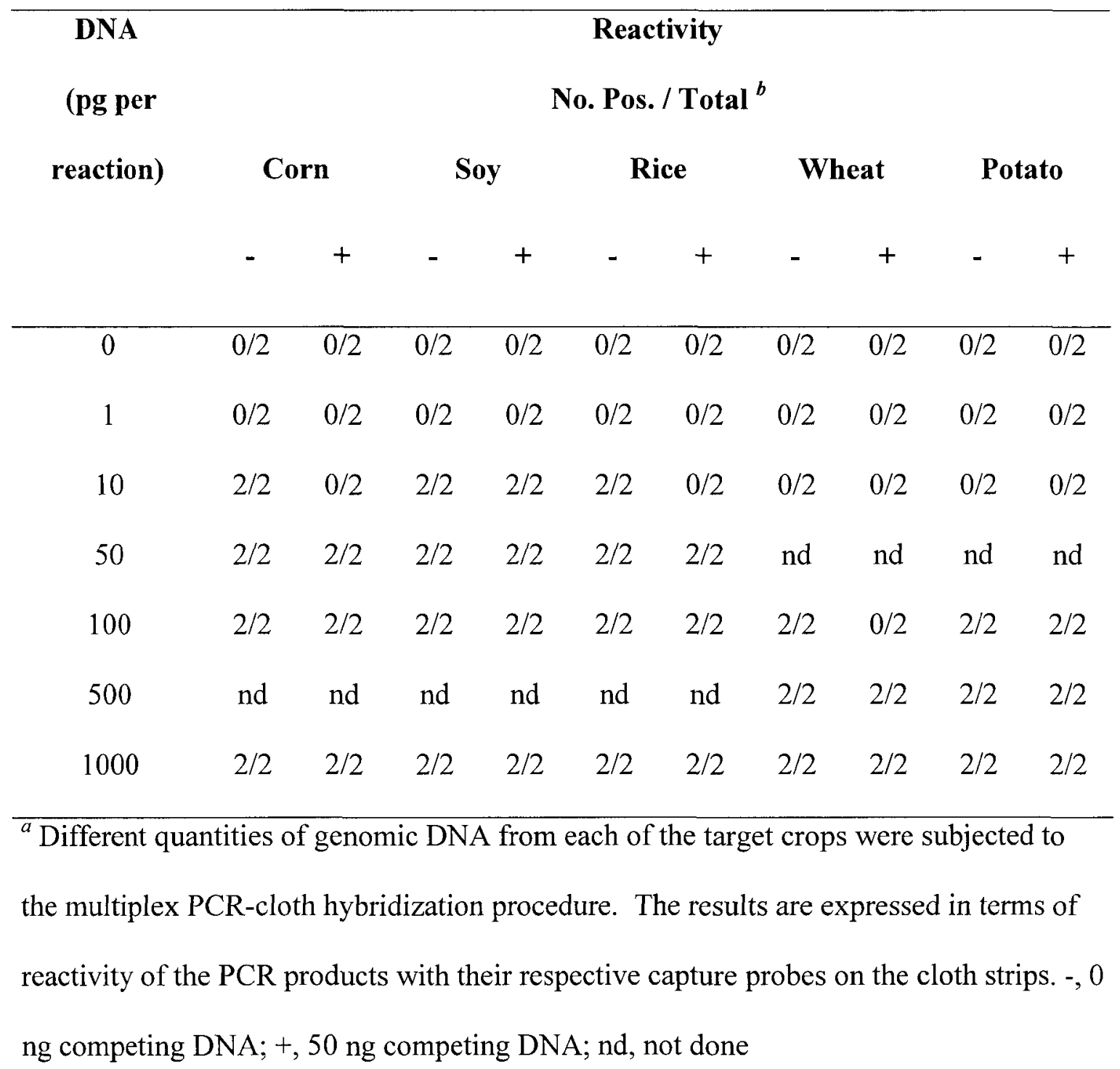

${ }^{b}$ Number of positives per total number of replicates tested. 
Analysis of flour blends. The preceding experiments illustrate the effectiveness of the multiplex PCR and CHAS procedure when assaying purified genomic DNA from each of the target plant crops. It is also necessary to evaluate the performance of the assay using actual food mixtures containing defined amounts of representative target crop in a bulk background of non-target food matrix. As a model system, flour blends were prepared containing different amounts of soy or corn blended in oat flour. Oat flour was chosen as a background matrix because this crop is not included in the panel of target plant species. Genomic DNA extracted from the flour blends was subjected to the multiplex PCR and CHAS procedure to determine the minimum concentration of target in each of the flours that would produce a positive result at their respective capture probes on the array. The soy flour blends produced positive signals with as low as $0.01 \%$ $(\mathrm{w} / \mathrm{w})$ soy flour; whereas the detectability for the corn flour blends was $0.5 \%(\mathrm{w} / \mathrm{w})$ (Table 4.4). The internal amplification control (IAC) was detected at all concentrations of the soy and corn flour blends, confirming the effectiveness of the PCR amplification process for all samples. 
Table 4.4. Detectability of multiplex PCR-CHAS in the assay of corn and soy flours ${ }^{a}$

\section{Reactivity}

Concentration

$\%(\mathbf{w} / \mathbf{w})$

No. Pos. / Total ${ }^{b}$

$\begin{array}{llll}\text { Zein SItn } & \text { RPD } & \text { Wx } & \text { IAC }\end{array}$

Corn blends

$\begin{array}{lllllll}5.0 & 2 / 2 & 0 / 2 & 0 / 2 & 0 / 2 & 0 / 2 & 2 / 2 \\ 1.0 & 2 / 2 & 0 / 2 & 0 / 2 & 0 / 2 & 0 / 2 & 2 / 2 \\ 0.5 & 2 / 2 & 0 / 2 & 0 / 2 & 0 / 2 & 0 / 2 & 2 / 2 \\ 0.1 & 0 / 2 & 0 / 2 & 0 / 2 & 0 / 2 & 0 / 2 & 2 / 2 \\ 0.05 & 0 / 2 & 0 / 2 & 0 / 2 & 0 / 2 & 0 / 2 & 2 / 2 \\ 0.01 & 0 / 2 & 0 / 2 & 0 / 2 & 0 / 2 & 0 / 2 & 2 / 2 \\ 0.001 & 0 / 2 & 0 / 2 & 0 / 2 & 0 / 2 & 0 / 2 & 2 / 2 \\ 0.0 & 0 / 2 & 0 / 2 & 0 / 2 & 0 / 2 & 0 / 2 & 2 / 2\end{array}$

Soy blends

\begin{tabular}{lllllll}
5.0 & $0 / 2$ & $2 / 2$ & $0 / 2$ & $0 / 2$ & $0 / 2$ & $2 / 2$ \\
1.0 & $0 / 2$ & $2 / 2$ & $0 / 2$ & $0 / 2$ & $0 / 2$ & $2 / 2$ \\
0.5 & $0 / 2$ & $2 / 2$ & $0 / 2$ & $0 / 2$ & $0 / 2$ & $2 / 2$ \\
0.1 & $0 / 2$ & $2 / 2$ & $0 / 2$ & $0 / 2$ & $0 / 2$ & $2 / 2$ \\
0.05 & $0 / 2$ & $2 / 2$ & $0 / 2$ & $0 / 2$ & $0 / 2$ & $2 / 2$ \\
0.01 & $0 / 2$ & $2 / 2$ & $0 / 2$ & $0 / 2$ & $0 / 2$ & $2 / 2$ \\
0.001 & $0 / 2$ & $0 / 2$ & $0 / 2$ & $0 / 2$ & $0 / 2$ & $2 / 2$ \\
0.0 & $0 / 2$ & $0 / 2$ & $0 / 2$ & $0 / 2$ & $0 / 2$ & $2 / 2$ \\
\hline
\end{tabular}


${ }^{a}$ Genomic DNA (10 ng) from corn and soy flour blended at various concentrations in oatmeal was subjected to the multiplex PCR-cloth hybridization procedure. The results are expressed in terms of reactivity of the PCR products with the corn zein, soy lectin, rice phospholipase $\mathrm{D}$, wheat waxy, potato sucrose synthase and IAC capture probes on the cloth strips.

${ }^{b}$ Number of positives per total number of replicates tested. 
Specificity. Genomic DNA was extracted from various crops that are phylogenetically similar to members of the crop CHAS panel to confirm the specificity of the combined multiplex PCR CHAS in exclusively detecting the intended target crops (Table 4.5). Template DNA (10 ng) from closely related plant species from members of the Solanaceae (relatives of potato), Poaceae (relatives of corn, rice and wheat), and Fabaceae (relatives of soy) families was subjected to the multiplex PCR-CHAS. A weak positive reaction was observed for barley with the wheat-specific capture probe. Barley (Hordeum vulgare) is a close relative of wheat that also possesses a gene coding for a barley Waxy protein (NCBI, X07932) having significant amino acid sequence similarity to the wheat waxy proteins (Gao and Chibbar, 2000; Zhang et al., 2001b), which may explain the observed cross reactivity between the two species. No other cross-reactivities were observed for any of the other closely related plant species tested, demonstrating the efficacy of the combined multiplex PCR CHAS in specifically detecting the intended target crop species. 
Table 4.5. Specificity of multiplex PCR-CHAS in the assay of various phylogenetically similar crops ${ }^{a}$

Template DNA

(10 ng per reaction)

\section{Reactivity}

No. Pos. / Total ${ }^{b}$

Family: Solanaceae

$\begin{array}{lllllll}\text { Potato (Solanum tuberosum) } & 0 / 2 & 0 / 2 & 0 / 2 & 0 / 2 & 2 / 2 & 2 / 2 \\ \text { Tomato (Solanum lycopersicum) } & 0 / 2 & 0 / 2 & 0 / 2 & 0 / 2 & 0 / 2 & 2 / 2 \\ \text { Green pepper (Capsicum annuum) } & 0 / 2 & 0 / 2 & 0 / 2 & 0 / 2 & 0 / 2 & 2 / 2 \\ \text { Eggplant (Solanum melongena) } & 0 / 2 & 0 / 2 & 0 / 2 & 0 / 2 & 0 / 2 & 2 / 2\end{array}$

Family: Poaceae

Corn (Zea mays)

$\begin{array}{llllll}2 / 2 & 0 / 2 & 0 / 2 & 0 / 2 & 0 / 2 & 2 / 2\end{array}$

Rice (Oryza sativa)

$\begin{array}{llllll}0 / 2 & 0 / 2 & 2 / 2 & 0 / 2 & 0 / 2 & 2 / 2\end{array}$

Wheat (Triticum aestivum)

$\begin{array}{llllll}0 / 2 & 0 / 2 & 0 / 2 & 2 / 2 & 0 / 2 & 2 / 2\end{array}$

Japanese millet (Echinochloa esculenta)

$0 / 2$

$0 / 2$

$0 / 2$

$0 / 2$

$0 / 2 \quad 2 / 2$

Barley (Hordeum vulgare)

$0 / 2$

$0 / 2$

$0 / 2$

$2 / 2$

$0 / 2 \quad 2 / 2$

Foxtail millet (Setaria italica)

$0 / 2$

$0 / 2$

$0 / 2$

$0 / 2$

$0 / 2 \quad 2 / 2$

Rye (Secale cereale)

$0 / 2$

$0 / 2$

$0 / 2$

$0 / 2$

$0 / 2 \quad 2 / 2$

Rice cutgrass (Leersia oryzoides )

$0 / 2 \quad 0 / 2$

$0 / 2$

$0 / 2$

$0 / 2 \quad 2 / 2$

Sorghum bicolor

$0 / 2$

$0 / 2$

$0 / 2$

$0 / 2$

$0 / 2 \quad 2 / 2$

Pearl millet (Pennisetum glaucum)

$0 / 2$

$0 / 2$

$0 / 2$

$0 / 2$

$0 / 2$

$2 / 2$ 


\begin{tabular}{lcccccc}
\hline Bamboo (Bambusa vulgaris) & $0 / 2$ & $0 / 2$ & $0 / 2$ & $0 / 2$ & $0 / 2$ & $2 / 2$ \\
Wild rice (Zizania aquatica) & $0 / 2$ & $0 / 2$ & $0 / 2$ & $0 / 2$ & $0 / 2$ & $2 / 2$
\end{tabular}

\section{Family: Fabaceae}

Soy (Glycine max)

$\begin{array}{llllll}0 / 2 & 2 / 2 & 0 / 2 & 0 / 2 & 0 / 2 & 2 / 2\end{array}$

Alfalfa sprouts (Medicago sativa)

$\begin{array}{llllll}0 / 2 & 0 / 2 & 0 / 2 & 0 / 2 & 0 / 2 & 2 / 2\end{array}$

Bean sprouts (Vigna radiata)

$\begin{array}{llllll}0 / 2 & 0 / 2 & 0 / 2 & 0 / 2 & 0 / 2 & 2 / 2\end{array}$

Green beans (Phaseolus vulgaris)

$\begin{array}{llllll}0 / 2 & 0 / 2 & 0 / 2 & 0 / 2 & 0 / 2 & 2 / 2\end{array}$

Navy beans (Phaseolus vulgaris)

$\begin{array}{llllll}0 / 2 & 0 / 2 & 0 / 2 & 0 / 2 & 0 / 2 & 2 / 2\end{array}$

Kidney beans (Phaseolus vulgaris)

$\begin{array}{llllll}0 / 2 & 0 / 2 & 0 / 2 & 0 / 2 & 0 / 2 & 2 / 2\end{array}$

Green split peas (Pisum sativum)

$0 / 2$

$0 / 2$

$0 / 2$

$0 / 2 \quad 0 / 2$

$2 / 2$

Red lentils (Lens culinaris)

$0 / 2$

$0 / 2$

$0 / 2$

$0 / 2 \quad 0 / 2$

Chick peas (Cicer arietinum)

$0 / 2$

$0 / 2$

$0 / 2$

$0 / 2$

$0 / 2$

$2 / 2$

Lima beans (Phaseolus lunatus)

$0 / 2$

$0 / 2$

$0 / 2$

$0 / 2$

$0 / 2$

$2 / 2$

${ }^{a}$ Genomic DNA (10 ng) from various crops was subjected to the multiplex PCR-cloth hybridization procedure. The results are expressed in terms of reactivity of the PCR products with the corn zein (Zein), soy lectin (Sltn), rice phospholipase D (RPD), wheat waxy (Wx), potato sucrose synthase (PSS) and internal amplification control (IAC) capture probes on the cloth strips.

\footnotetext{
${ }^{b}$ Number of positives per total number of replicates tested.
} 
Food Samples. The performance of the crop CHAS was verified using extracted genomic DNA from a variety of different retail food products with defined ingredients listed on the packaging label (Table 4.1) obtained from a local grocery store in order to ascertain the ability of the multiplex PCR and CHAS procedure to detect specific ingredients in processed foods (Table 4.6).

Upon comparison of the declared ingredients in each of the retail food samples (Table 4.1) to the results listed in Table 4.6, the expected reactivities were observed for certain ingredients in only a few of the retail food products subjected to the crop CHAS procedure. Rice was detected in all of the expected samples (i.e., the canned chicken and rice soup, the dry garlic and vegetable rice noodle soup mix, and the corn casserole baby food) and wheat was detected in one of the expected samples (the garden vegetable dry soup mix). However, the target ingredients for the majority of the retail food products (i.e., potatoes from the canned mixed vegetables, corn in the corn casserole baby food, potatoes and wheat in the canned Irish stew, corn in the garden vegetable dry soup mix and soy in the canned vegetarian chili) were not detected by this assay. The importance of including an internal amplification control as an indicator of PCR amplification efficiency has been demonstrated, as the IAC failed to amplify using template DNA from the Old Elpaso Fajita Seasoning Mix and the Campbell's Franco-American Turkey Gravy, suggesting PCR inhibitory substances were co-purified with the extracted DNA, thus invalidating the analysis. 
Table 4.6. Detectability of multiplex PCR-CHAS in the assay of extracted DNA from processed foods $^{a}$

Template DNA (10-50 ng per reaction)

Reactivity

No. Pos. / Total ${ }^{b}$

Zein Sltn RPD Wx PSS IAC

Canned mixed vegetables ${ }^{c}$

$\begin{array}{llllll}0 / 2 & 0 / 2 & 0 / 2 & 0 / 2 & 0 / 2 & 2 / 2\end{array}$

Chicken and Rice Soup ${ }^{c}$

$\begin{array}{llllll}0 / 2 & 0 / 2 & 2 / 2 & 0 / 2 & 0 / 2 & 2 / 2\end{array}$

Garden Vegetable with Whole Wheat Penne Pasta dry

$\begin{array}{llllll}0 / 2 & 0 / 2 & 0 / 2 & 2 / 2 & 0 / 2 & 2 / 2\end{array}$
soup $\operatorname{mix}^{c}$

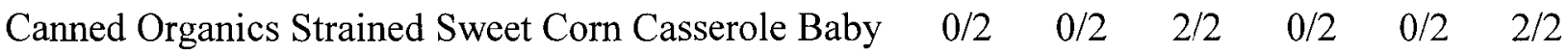
Food $^{d}$

Dry Fajita Seasoning Mix ${ }^{d}$ $\begin{array}{llllll}0 / 2 & 0 / 2 & 0 / 2 & 0 / 2 & 0 / 2 & 0 / 2\end{array}$

Canned Turkey Gravy ${ }^{d}$ $\begin{array}{llllll}0 / 2 & 0 / 2 & 0 / 2 & 0 / 2 & 0 / 2 & 0 / 2\end{array}$

Dry Garlic \& Vegetable instant rice noodle soup mix ${ }^{e}$ $\begin{array}{llllll}0 / 2 & 0 / 2 & 2 / 2 & 0 / 2 & 0 / 2 & 2 / 2\end{array}$ Canned Irish Stew ${ }^{e}$ $\begin{array}{llllll}0 / 2 & 0 / 2 & 0 / 2 & 0 / 2 & 0 / 2 & 2 / 2\end{array}$

Canned Vegetarian Chili ${ }^{e}$ $\begin{array}{llllll}0 / 2 & 0 / 2 & 0 / 2 & 0 / 2 & 0 / 2 & 2 / 2\end{array}$

PCR reagent blank (MQ water)

$\begin{array}{llllll}0 / 2 & 0 / 2 & 0 / 2 & 0 / 2 & 0 / 2 & 2 / 2\end{array}$

${ }^{a}$ Genomic DNA (10-50 ng) from various processed food samples was subjected to the multiplex PCR-cloth hybridization procedure. The results are expressed in terms of reactivity of the PCR products with the corn zein (Zein), soy lectin (SItn), rice phospholipase D (RPD), wheat waxy (Wx), potato sucrose synthase (PSS) and internal amplification control (IAC) capture probes on the cloth strips. 
${ }^{b}$ Number of positives per total number of replicates tested.

${ }^{c}$ DNA extracted using Qiagen DNeasy Maxi kit as described in Methods

${ }^{d}$ DNA extracted from sample using modified Wizard as described in Methods

${ }^{e}$ Sample ground in liquid nitrogen followed by DNA extraction using modified Wizard as described in Methods 
These results highlight the difficulties associated with the application of molecular techniques for the identification of ingredients present in highly processed foodstuffs, as the DNA extracted from such samples can often be degraded beyond amplifiability. In general, DNA is not amplifiable in food products subjected to conditions of high heat, hydrolyzed plant proteins, starch derivatives, and defined chemical substances such as sugars and refined plant oils (Meyer, 1999). In an attempt to mimic conditions commonly encountered by food processing methods, Bauer et al. (2003) examined the effects of parameters such as $\mathrm{pH}$ and temperature on DNA degradation, and found that both parameters had a significant impact on the degree of DNA degradation in foods. DNA degradation was most pronounced under acidic conditions, and the extent of degradation increased with both increased temperature and exposure time. Chen et al. (2005) examined the amplifiability of exogenous and endogenous gene segments of differing lengths using template genomic DNA from RoundUp Ready soy extracted at different steps of critical processing procedures commonly used in the preparation of soy for various foodstuffs. The authors found that the sterilization procedure, where the sample is subjected to conditions of high heat and pressure, significantly degraded the DNA such that PCR amplification only occurred for primer pairs targeting gene segments less than $200 \mathrm{bp}$ for both the endogenous and exogenous genes, as longer gene segments were no longer amplifiable (Chen et al., 2005). Such conditions of high heat and pressure mirror the conditions used in the canning process, which most likely results in only very highly degraded DNA being extracted from these samples. Interestingly, when DNA was extracted from the 
commercial samples and used as template in the combined multiplex PCR and CHAS, positive results were obtained for only the rice and wheat targets, the two shortest amplicons of 123 and $102 \mathrm{bp}$, respectively.

Further hindering the detection of target sequences from the processed foods were the low yields of extracted DNA that were obtained for each of the samples $(<10 \mathrm{ng} / \mu \mathrm{l})$ using both the Qiagen and modified Wizard extraction protocols. Therefore, in a mixed sample where only low amounts of the target analyte are present, and using extraction procedures in which the amount of starting material is limited to between 0.2 and $1.0 \mathrm{~g}$, the resulting extracted DNA may not be representative of the whole sample. Moreano et al. (2005) found that in addition to the lengths of the selected target sequences being critical parameters in determining the detectability of PCR-based assays, DNA extraction yields were much greater for samples of smaller particle size, perhaps due to the larger surface area of the smaller particles resulting in greater exposure to DNA extraction reagents. Consequently, in foods that contain fractions of differing particle size, the extraction efficiency may be favoured for one ingredient over another, again resulting in extracted DNA that may not be representative of the entire sample being analyzed.

These studies demonstrate the applicability of the combined multiplex PCR and CHAS procedure in detecting target gene sequences from corn, soy, rice, wheat and potato, which may be used as a preliminary screening tool to confirm which ingredients are present in a sample prior to analyzing the sample for a crop-specific transgenic event or polymorphic site. While low limits of detection were obtained when assaying purified 
genomic DNA from each of the crops, and for both the corn and soy flours blended in oatmeal $(0.5$ and $0.01 \%$, respectively), these studies emphasize the need for the development of ultrasensitive assays for the detection of target analytes in highly processed samples, where harsh processing conditions can result in high levels of DNA degradation. Failure to detect a particular target from the highly processed foods by the multiplex PCR crop CHAS procedure may also translate into the inability to detect transgenic elements for that crop as well. The crop CHAS system may therefore serve as a verification of the amplifiability of the DNA target(s), in addition to being a screening tool to confirm which ingredients are present in a mixed food sample. Furthermore, the results of this work underscore the importance of including an internal amplification control for samples analyzed by nucleic acid amplification techniques, as PCR inhibitory substances appeared to have been co-purified with extracted DNA from two of the highly processed food samples, a common occurrence when extracting DNA from complex matrices such as foods. Future work may be necessary to examine whether the effectiveness of the combined multiplex PCR and CHAS in detecting specific ingredients in highly processed foods would be improved if primer pairs were redesigned to amplify smaller gene fragments $(<150 \mathrm{bp})$ of similar size for each of the crops. 


\section{Chapter 5}

\section{General Conclusions}


This thesis has focused on the development of methods for the detection of genetically modified organisms in foods, with an emphasis on critical quality control points relating to DNA-based detection strategies. Methods that utilize nucleic acid amplification technology require an accurate assessment of the quantity of DNA to be used as template in the amplification reaction to ensure that the concentration of template is in the prescribed range to enable efficient amplification. It is recommended that the quantity of DNA to be used as template in the PCR should be limited to below 100 or $200 \mathrm{ng}$, as too great a concentration of template tends to have an inhibitory effect on the reaction (Miraglia et al., 2004). The extraction of DNA from different sample matrices, and utilization of different extraction and purification procedures, can result in DNA preparations of varying degrees of purity, necessitating quantification procedures that are unaffected by the presence of impurities that may be co-extracted with the DNA sample. Additionally, food samples can often be highly processed through heating, pressurization and sterilization, such that DNA extraction procedures can result in very low yields of DNA, necessitating sensitive DNA quantification procedures that utilize low sample volumes for analysis. This thesis addressed the need for an accurate and sensitive method for DNA quantification through the development of a microplate assay utilizing the fluorescent stain SYBR Green I for DNA quantification in which fluorescence is quantified by measurement with a fluorescence plate reader. This microplate fluorescence assay (MFA) exhibited excellent accuracy and linearity over a broad range of DNA concentrations that spanned four orders of magnitude $(0.25$ to $2500 \mathrm{pg} / \mu \mathrm{l})$, and exhibited superior detection sensitivity characteristics when compared to quantification 
using spectrophotometric methods based on ultraviolet absorption, and to the Hoefer DyNA Quant ${ }^{\circledR} 200$ fluorometric assay.

The applicability of the MFA was demonstrated in the analysis of real world samples in Chapter 4 of this thesis. Two different DNA extraction procedures resulted in very low yields of DNA from processed food samples, which necessitated a highly sensitive DNA quantification procedure that utilized low sample volumes for analysis. The MFA met this requirement in a convenient, 96-well format, which permitted high sample throughput capacity, with minimal consumption of the total available sample.

In addition to the requirement for sensitive and accurate DNA quantification procedures when utilizing methods that employ nucleic acid amplification technology, it is also necessary to have the appropriate control measures in place to verify the efficiency of the amplification reaction. PCR inhibitory substances can often be co-extracted with the DNA sample, especially when extracting DNA from complex sample matrices such as foods. Many quality assurance schemes require that the presence of inhibitors be ruled out through the inclusion of an internal amplification control in the PCR system. This thesis addressed this issue through the development of an internal amplification control (IAC) system as an indicator of PCR amplification efficiency. This exquisitely simple IAC system was based on the inclusion of two oligonucleotide primers with complementary 3' ends in the PCR mixture that annealed to form a small "primer-dimer" like product that was detectable by hybridization with its corresponding capture probe in a cloth-based hybridization array system (CHAS), and was also detectable by agarose gel 
electrophoresis analysis. The IAC system developed in this thesis offers a simple means of avoiding reporting false negative results due to the presence of sample inhibitors in the PCR. As the IAC system is template-independent, it can easily be incorporated into a PCR system without the preparation of specialized templates, thus serving as a broadly applicable and effective tool for incorporation in laboratory quality assurance schemes.

The applicability of the IAC was demonstrated in the analysis of real world samples in Chapter 4 of this thesis, as the IAC failed to amplify in the analysis of extracted DNA from two of the processed food samples. This observation suggested that PCR inhibitory substances were co-purified with the extracted DNA from these samples, a common occurrence when extracting DNA from complex sample matrices such as foods. Future experiments may need to be performed to ascertain the effectiveness of the IAC in different systems, such as the amplification of target gene sequences from bacterial or mammalian systems, or in a multiplex-PCR amplifying a greater number of target sequences than those tested in this thesis.

The traditional approach of applying single target-specific PCR methods for the detection of genetically modified organisms in foods is becoming increasingly impractical as the number of transgenic elements being introduced into different plant crops continues to increase. For many individual crop species there are numerous possible transgenic elements. Consequently, in a mixed food sample containing multiple crops, the number of different transgenic elements to test for can become quite cumbersome. Therefore, there is a need to narrow the field of different possible choices 
of individual, target-specific tests that need to be carried out on a mixed food sample to eliminate any unnecessary tests and to make the testing of foods more practical. A more practical approach would be to perform a limited number of tests to ascertain which specific ingredients are present in the mixed food sample, followed by further testing for known transgenic elements that are relevant to the specific ingredients detected in the sample. This thesis addressed this matter through the development of a cloth-based hybridization array system (CHAS) for the detection of specific endogenous gene sequences from five different common food crops (corn, soy, rice, wheat and potato) as a preliminary screening tool to ascertain which ingredients are present in a mixed food sample, and to verify the amplifiability of the DNA from the targets that are present. The five crops chosen represent a selection of common food crops for which genetically modified versions are approved for cultivation or import into Canada, and are therefore the most likely to harbour transgenic elements.

The combined multiplex-PCR and crop-specific CHAS procedure proved effective in the detection of target gene sequences from each of the five crop species when analyzing purified genomic DNA from each of the crops, and when assaying DNA extracted from varying amounts of corn and soy flours blended in oatmeal. However, the expected reactivities were observed for certain targets in only a few of the samples when the assay was utilized for the detection of the individual targets from highly processed foods. Failure to detect a particular target from the highly processed samples using the multiplex-PCR and crop CHAS procedure may also translate into the inability to detect specific transgenic elements for that crop as well. Therefore, in addition to the crop 
CHAS serving as a screening tool to ascertain which specific ingredients are present in a mixed food sample, this system may also serve as an indicator of the amplifiability of the DNA target(s). The lack of detection of certain crops from the food samples highlights the difficulties associated with the identification of targets in highly processed foodstuffs, and emphasizes the need for the development of ultrasensitive assays for the detection of analytical targets from such samples. Future experiments may need to be performed to examine whether the effectiveness of the combined multiplex PCR and CHAS in detecting specific ingredients in highly processed foods would be improved if the primer pairs used in this thesis were redesigned to amplify smaller gene fragments (i.e., less than $150 \mathrm{bp}$ ) for each of the target crops. Furthermore, the development of a PCR system employing primer pairs specific to a particular gene sequence common to all plants could be studied as a means to verify the level of degradation of the extracted plant DNA from a food sample. In such a system, various primer pairs could be chosen that target DNA segments of varying lengths (i.e., $100 \mathrm{bp}, 200 \mathrm{bp}$, etc.) as an indicator of the amplifiability of the extracted DNA.

In certain instances, it may be desirable to use protein-based detection methods for the identification of genetically modified ingredients in food samples. However, most protein-based detection systems, such as enzyme-linked immunosorbent assays (ELISAs), are often limited in terms of their detection sensitivity. Highly sensitive assays for the detection of proteins are especially important when analysing highly processed samples, such as foods. As a possible means to boost the detection sensitivity of protein based detection methods, this thesis addressed preliminary attempts to develop 
an ultrasensitive detection system employing a synthetic, transcribable DNA fragment as an indicator molecule to label antibodies for enzyme-immunoassay applications to enable the detection of protein from highly processed samples. The preliminary results of this work are presented in Appendix A of this thesis. 
Appendix A

Development of an ultrasensitive immunoassay for the detection of trace amounts of protein in highly processed food samples 


\begin{abstract}
The development of an ultrasensitive assay system employing a synthetic transcribable DNA fragment as an indicator molecule to label antibodies for enzyme immunoassay applications was attempted using chicken IgY as a model antigenic analyte detected in a microwell enzyme immunoassay format. A biotinylated, transcriptionally active DNA fragment was generated during PCR synthesis using a 5'-biotinylated reverse primer and a forward primer with an additional sequence of nucleotides specific for a bacteriophage promoter region, which was subsequently linked to a biotinylated-anti-chicken IgY via a streptavidin bridge. Bound amplicon was converted to multiple RNA copies by the addition of a transcription reaction mixture containing ribonucleotides and RNA polymerase, and the transcripts detected using SYBR Green II dye or by utilizing a suitable molecular beacon probe that exhibits fluorescence only when bound to its RNA target, and the final signal monitored using a fluorescence plate reader. Further amplification of the transcription signal was attempted using the isothermal Nucleic Acid Sequence-Based Amplification (NASBA) reaction.
\end{abstract}

\title{
INTRODUCTION
}

The development of rapid and ultrasensitive assays is required for the detection of trace amounts of target substances in analytical samples. Rapid assays are especially important in the food industry, where there is pressure by regulators to ensure the safety of the food supply for consumers, while also providing contaminant-free food on the market prior to the product's expiry date. The development of ultrasensitive assays is important because food matrices can be highly processed through heating, pressurization and sterilization, 
and often contain only trace amounts of target in a detectable form (i.e., non-denatured protein, non-degraded nucleic acid). In food sources there are a variety of different types of adulterants that can be present in trace amounts, including pathogenic bacteria that may cause severe foodborne illness, or undeclared ingredients that may cause a severe allergenic response in certain individuals (or otherwise be unacceptable to consumers). For the detection of potentially allergenic proteins in food samples, it is necessary to develop analytical methods that are both specific and sensitive, since only trace amounts of these proteins can cause an allergenic response (Baumgartner et al., 2002). Enzymelinked immunosorbent assays (ELISAs) are protein-based assays commonly used for the detection of potential allergens in food products (Stephen et al., 2002; Blais et al., 2003). Such assays utilize an enzyme-labelled antibody specific to the target protein followed by the addition of substrate to yield a colourimetric response should the target protein be present. However, such immunological-based methodologies are limited in terms of their detection sensitivity, and are therefore not suited for the analysis of highly processed samples, such as foods, that may contain only trace amounts of protein in a detectable form.

When nucleic acid amplification techniques are used for signal generation in antibody-based assays, the detection sensitivity of the conventional immunoassay can be dramatically increased. The development of Immuno-PCR by Sano et al. (1992) offered a means of boosting the detectability of immunoassays by approximately $10^{5}$-fold when compared to a conventional sandwich ELISA that utilized an alkaline phosphatase conjugated detector antibody with subsequent substrate conversion as the detection 
system. In Immuno-PCR, a linker molecule with binding affinity for both a DNA fragment and an antibody is used to attach a DNA molecule to an antibody, which is used to bind to a specific analyte in an immunoassay format. The attached DNA fragment is amplified by PCR and any amplified product (visualized by agarose gel electrophoresis and ethidium bromide staining) is indicative of the presence of antigen (Sano et al., 1992). Although immuno-PCR was shown to have superior detection sensitivity over traditional ELISA, post-amplification handling was required to analyze the Immuno-PCR product, thus increasing the risk of product contamination that could lead to the reporting of false-positive results. The requirements for thermal cycling and product analysis by agarose gel electrophoresis have therefore restricted the widespread adoption of ImmunoPCR over traditional ELISAs.

Zhang et al. (2001a) developed an isothermal, linear nucleic acid amplification technique for signal generation in an immunoassay format termed Immuno-detection amplified by T7 RNA polymerase (IDAT). This method combined the specificity of antigen-antibody interactions with the detection sensitivity powered by the linear amplification of RNA by T7 RNA polymerase. In the same manner as Immuno-PCR, a DNA fragment is linked to an antibody that is used to bind antigen in an immunoassay format. This DNA fragment contains a specific sequence of nucleotides that make up the promoter region that is required by the $\mathrm{T} 7$ polymerase to bind in order to initiate transcription. Multiple T7 RNA polymerase enzymes bind in a consecutive and progressive manner and proceed to transcribe multiple copies of RNA. This assay is isothermal, thus avoiding the need for thermocycling. The IDAT assay was reported to 
have a $10^{9}$-fold increase in detection sensitivity over a conventional sandwich ELISA (Zhang et al., 2001a). The major drawback of this assay was that for sensitive detection of the transcribed RNA, radioactive $\alpha-\left[{ }^{32} \mathrm{P}\right] \mathrm{ATP}$ was incorporated into the amplification reaction mix.

The development of an ultrasensitive assay system employing a synthetic transcribable DNA fragment as an indicator molecule to label antibodies for enzyme immuno-assay (EIA) applications was attempted to enable the detection of trace amounts of protein in complex, highly processed food samples. The detection of Chicken IgY in a microwell enzyme immuno-assay (EIA) format was used as a model system because this material and its attendant reagent antibodies are readily available from commercial sources. A transcribable DNA fragment was generated during PCR synthesis using a primer with an additional 5'-appended sequence of nucleotides specifying the SP6 or T7 (depending on the sequence of nucleotides) bacteriophage promoter. It was surmised that a DNA fragment bearing the upstream bacteriophage promoter could be subsequently converted to multiple RNA copies in an in vitro transcription reaction, and the RNA transcripts detected using a fluorescent dye exhibiting higher fluorescence intensity when bound to single-stranded RNA than when bound to double-stranded DNA (Fig. A.1), or by utilizing a suitable molecular beacon probe exhibiting fluorescence only when bound to its RNA target. Further amplification of the transcription signal was attempted using Nucleic Acid Sequence-Based Amplification (NASBA), a reaction that is capable of exponentially amplifying RNA, in combination with a fluorescent dye or molecular beacon probe with subsequent signal detection using a fluorescence plate reader. 


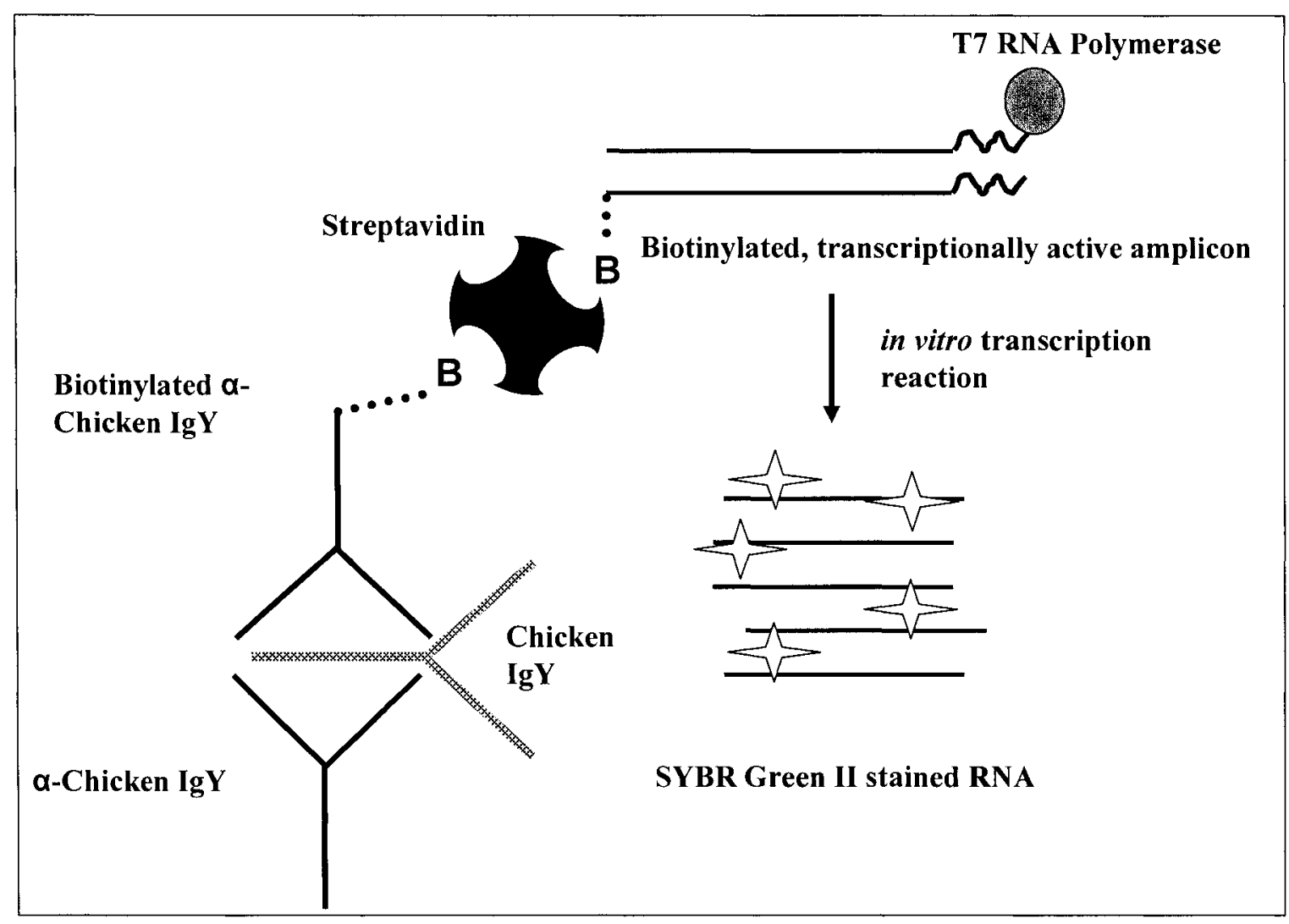

Figure A.1. Schematic representation of the ImmunoScript assay. Anti-chicken IgY will be immobilized in the wells of a microtiter plate, followed by reaction with a test sample containing chicken IgY (the analyte of interest). Captured IgY will be detected by sequential reactions with biotinylated anti-chicken IgY, streptavidin and biotinylated transcriptionally active DNA (TDNA). Bound TDNA will be detected by addition of a transcription reaction mixture containing ribonucleotides and T7 RNA polymerase, with transcript detection using a suitable fluorescent dye, and the final signal monitored in a fluorescence plate reader. 


\section{MATERIALS AND METHODS}

Transcribable DNA fragment design and production. For the generation of a transcriptionally active and biotinylated PCR product based on the $35 \mathrm{~S}$ CaMV promoter region of RoundUp Ready soy, transgenic soy seeds (Roundup Ready, variety S14M7RR) were used for the preparation of template DNA as previously described (Lipp et al., 1999). PCR conditions for producing promoter-appended DNA products for use in transcriptional enhancement experiments were optimized using a high fidelity, proofreading DNA polymerase, KOD HotStart HiFi (Novagen). A segment of DNA from the $35 \mathrm{~S}$ CaMV promoter region of RoundUp Ready soy was amplified by PCR using a primer with a specific sequence of additional nucleotides appended to the 5 , end to generate a DNA fragment with a functional RNA polymerase promoter region. Depending on the sequence of additional nucleotides incorporated during PCR, the promoter region was specific for an RNA polymerase encoded by either bacteriophage T7 or SP6, as these phage RNA polymerases are highly specific for their own unique promoter sequences (Jorgensen et al., 1991).

The primer pair targeting the $35 \mathrm{~S}$ region of RR soy was as described by Lipp et al. (1999), except that the forward primer was modified to contain an additional sequence of nucleotides appended to the 5' end corresponding to either T7 or SP6 promoter sequences, and the reverse primer was 5'-biotin labelled. For the PCR, ten $\mu$ l of RR soy template $(1 \mathrm{ng} / \mu \mathrm{l})$ was added to $40 \mu \mathrm{l}$ reaction mixture with 2.5 units KOD HotStart DNA polymerase and $1 \mathrm{X}$ PCR buffer for KOD polymerase, $1 \mathrm{mM} \mathrm{MgSO}_{4}, 0.02 \mu \mathrm{g} \mathrm{BSA}$, 
$200 \mu \mathrm{M}$ each dNTP (Promega Corporation), $0.4 \mu \mathrm{M}$ each of primers (with the RNA promoter sequences underlined): T7-35S-1 (5'-CTAATACGACTCACTATAGGG GCTCCTACAAATGCCATCATT-3') or SP6-35S-1 (5'-ATTTAGGTGACACTA TAGAAGAGGCTCCTACAAATGCCATCATT-3') and Biotin-35S-2 (5'-BiotinGATAGTGGGATTGTGCGTCA-3'). The PCR was performed using a Mastercycler gradient thermal cycler (Eppendorf, Westbury, NY) using the following program: initial heating at $94^{\circ} \mathrm{C}$ for $2 \min 30 \mathrm{~s}$, followed by 38 cycles of denaturation at $94^{\circ} \mathrm{C}$ for $30 \mathrm{~s}$, annealing at $58^{\circ} \mathrm{C}$ for $30 \mathrm{~s}$ and primer extension at $72^{\circ} \mathrm{C}$ for $15 \mathrm{~s}$. A final extension at $72^{\circ} \mathrm{C}$ for $15 \mathrm{~s}$ followed the last cycle. After amplification, PCR products were pooled and purified using the QIAquick PCR Purification kit (Qiagen), following the manufacturer's instructions. The purified PCR product was quantified using a SYBR Green I microplate fluorescence assay as described by Leggate et al. (2006) and in Chapter 2 of this thesis.

Optimization of transcription conditions. Using T7 or SP6 RNA polymerase, RNA was transcribed from varying concentrations of the appropriate template DNA fragment. The transcription product yields were analyzed by staining with SYBR Green II stain, and the fluorescence measured at $485 / 518 \mathrm{~nm}$ using a fluorescence plate reader. The in vitro transcription reaction was carried out by adding ten- $\mu$ l of the T7 or SP6promoter appended PCR amplicon (varying concentrations) to $90 \mu \mathrm{l}$ of transcription reaction mix to yield final concentrations as follows: $40 \mathrm{mM}$ Tris- $\mathrm{HCl}(\mathrm{pH} 7.9), 6 \mathrm{mM}$ $\mathrm{MgCl} 2,2 \mathrm{mM}$ Spermidine, $10 \mathrm{mM} \mathrm{NaCl}, 10 \mathrm{mM}$ dithiothreitol, $0.5 \mathrm{mM}$ of each ribonucleotide (Promega), $40 \mathrm{U}$ of RNasin (Promega), 1: 20,000 dilution of SYBR Green II (Sigma) and varying amounts of T7 or SP6 RNA polymerase (Promega) in RNase-free, 
deionized, distilled water (Nanopure). The optimized transcription conditions were used for the development of the ImmunoScript assay.

Development of the ImmunoScript Assay. The optimized transcription conditions were utilized for the development of the ImmunoScript assay using chicken IgY as a model antigenic analyte detected in a microwell enzyme immuno-assay (EIA) format. Anti-chicken IgY, whole molecule, developed in rabbit (Sigma Aldrich, C-2288) was diluted in $0.01 \mathrm{M}$ phosphate buffered ( $\mathrm{pH} 7.4) / 0.85 \% \mathrm{NaCl}(\mathrm{PBS})$ to a final concentration of $10 \mu \mathrm{g} / \mathrm{ml}$ for coating the wells of Nunc TopYield microtiter plate strips, and $200 \mu \mathrm{l}$ of the solution was pipetted into each well. The plate was sealed with tape and incubated at $37^{\circ} \mathrm{C}$ for $20 \mathrm{~h}$, then washed six times with $300 \mu \mathrm{l}$ of PBS containing 0.05\% v/v Tween-20 (PBST) using a Wellwash AC plate washer (Thermo Labsystems). The plate was blocked by adding $200 \mu \mathrm{l}$ of a $5 \%(\mathrm{w} / \mathrm{v})$ solution of Bovine serum albumin (BSA) (EMD, EM-2930) in PBS to each well, and incubated for 1 -hr at $37^{\circ} \mathrm{C}$ and the plate was washed with PBST as before. One hundred $\mu$ l of chicken IgY (Sigma Aldrich, I-4881, varying concentrations, diluted in PBS) were added to each well, incubated at room temperature for 30 -min, and washed as above. Bound chicken IgY molecules were detected by reacting the wells with $100 \mu \mathrm{l}$ of biotinylated anti-chicken IgY (prepared using the Pierce Biotinylation kit per the manufacturer's instructions, cat. no. 21430) diluted 1:1000 in PBST containing 0.5\% (v/v) BSA (PBST-B) for $30 \mathrm{~min}$ at room temperature and the plate washed as before. The wells were then reacted with $100 \mu$ of streptavidin diluted to $1 \mu \mathrm{g} / \mathrm{ml}$ in PBST-B at room temperature for $30-\mathrm{min}$. After incubation, the wells were washed as above and $100 \mu \mathrm{l}$ of a $1 \mathrm{ng} / \mu \mathrm{l}$ solution of 
biotinylated-transcriptionally active amplicon incorporating a T7 RNA polymerase promoter region were added to each well and incubated for 30 -min at room temperature and washed with PBST as before. One hundred $\mu 1$ of a transcription reaction mixture (TRM) were added to each well (concentrations as above, but with $80 \mathrm{U}$ of $\mathrm{T} 7$ polymerase) and the plate incubated at $37^{\circ} \mathrm{C}$ for 3 -hours, followed by scanning with a Fluoroskan Ascent plate reader (Thermo Labsystems) fitted with a 485/518 nm excitation/emission filter set.

Comparison of ImmuoScript assay to a traditional sandwich ELISA. The detection sensitivity of the ImmunoScript assay was compared to that of a traditional sandwich ELISA using both chromogenic [3,3',5,5'-tetramethylbenzidine (TMB) Microwell peroxidase substrate 1-component no. 50-76-05, KPL, Gaithersburg, MD, USA] or fluorogenic (Amplex Red hydrogen peroxide/peroxidase substrate kit, no. A22188, Molecular Probes, Inc., Eugene, OR, USA) substrate systems. The assay was performed as described above, except that in place of the unlabelled streptavidin, $100 \mu 1$ of a $0.25 \mu \mathrm{g} / \mathrm{ml}$ solution of streptavidin-peroxidase (diluted in PBST-B) were added to each well. Following incubation for 30-min and washing in PBST as before, $100 \mu$ of either of the following were added to each well: (a) TMB, reacted in the wells for 30-min, followed by the addition of $50 \mu \mathrm{l}$ of $1 \mathrm{M} \mathrm{H}_{2} \mathrm{SO}_{4}$ and the absorbance read at $450 \mathrm{~nm}$ in a $\mu$ Quant microplate reader (Bio-Tek Instruments, Inc., Winooski, VT, USA); or (b) Amplex Red (prepared according to the manufacturer's instructions) reacted in the wells for 30-min, followed by scanning with the Fluoroskan Ascent fluorescence plate reader fitted with a $530 / 590 \mathrm{~nm}$ excitation/emission filter set. 
Development of Immuno-NASBA. To further boost the detection sensitivity of the ImmunoScript assay, the development of Immuno-NASBA was attempted. The assay was performed as described above, with the exception that (in place of the TRM), $50 \mu 1$ of a NASBA reaction mixture (NRM) that contained the following were added to each well: $40 \mathrm{mM}$ Tris-HCl, pH 8.5, $50 \mathrm{mM} \mathrm{KCl,} 2 \mathrm{mM}$ each rNTP, $1 \mathrm{mM}$ each dNTP, 12 $\mathrm{mM} \mathrm{MgCl} 2,10 \mathrm{mM}$ dithiothreitol, $0.2 \mu \mathrm{M}$ each of primers T7-35S-1 and 35S-2, $5.2 \mu \mathrm{g}$ BSA, 15\% v/v DMSO, 80 U T7 RNA polymerase, 16 U AMV Reverse Transcriptase, 0.4 $\mathrm{U}$ RNase $\mathrm{H}$, and $25 \mathrm{U}$ RNasin. The plate was sealed with tape and incubated at $41^{\circ} \mathrm{C}$ for 3-h. Due to high background observed when staining the transcription products with SYBR Green II, the NASBA product was detected using molecular beacon probes added to the NRM following the 3-hr incubation (stem portions underlined: 5'-Fluorescein-

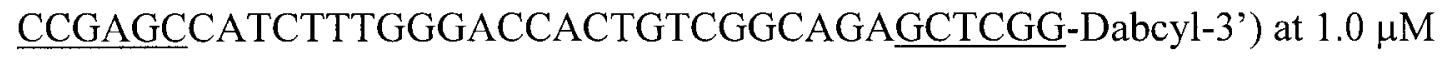
final concentration, followed by scanning with the Fluoroskan Ascent fluorescence plate reader fitted with a $485 / 518 \mathrm{~nm}$ excitation/emission filter set.

\section{Generation and utilization of shortened $35 \mathrm{~S}$ fragment for use in Immuno-}

NASBA. A shortened (137 bp), transcriptionally active amplicon was generated by PCR (same PCR conditions as described above) using the following biotinylated primer (in place of 35S-2): 5'-Biotin-GTCTTCTTTTTCCACGATGC-3' (35S-5). This biotinylated-TDNA fragment was used as the detector molecule in the Immuno-NASBA reactions performed as described above. 


\section{RESULTS AND DISCUSSION}

Optimization of transcription conditions. Prior to the development of the ImmunoScript assay, the optimum conditions for transcription of the promoter-appended amplicon were examined using serially diluted amounts of transcriptionally active template amplicon. Transcription yields were estimated by staining the RNA products with SYBR Green II, a fluorescent dye that exhibits higher fluorescence intensity when bound to single-stranded RNA than when bound to double-stranded DNA.

Transcriptionally active DNA fragments were generated by PCR synthesis using a primer pair targeting a region of the CaMV 35 S promoter of RoundUp Ready soy as described previously (Lipp et al., 1999), except the forward primer was modified to contain an additional sequence of nucleotides appended to the 5 ' end to generate a DNA fragment with a functional RNA polymerase promoter. Depending on the sequence of additional nucleotides incorporated during PCR, the promoter was specific for an RNA polymerase encoded by either bacteriophage T7 or SP6. To date, T7 RNA polymerase has been more commonly used in in vitro transcription or nucleic acid sequence-based amplification reactions than SP6 RNA polymerase. Although less extensively studied, SP6 RNA polymerase is closely related to T7 RNA polymerase, and in the presence of the appropriate double stranded sequence of nucleotides making up the SP6 promoter, the SP6 RNA polymerase is also capable of efficiently synthesizing RNA sequences in vitro, and has therefore been suggested as an alternative to T7 RNA polymerase for in vitro transcription applications (Stump and Hall, 1993; Shin et al., 1999). Transcription yields were compared by subjecting different quantities of T7-promoter appended or SP6- 
promoter appended amplicon to an in vitro transcription reaction using 10 units of the appropriate RNA polymerase (T7 or SP6, depending on the template amplicon used) (Fig. A.2). These preliminary results suggested that the SP6 system produced higher yields than the T7 system (Fig. A.2) However, upon comparison of transcription yields obtained using different amounts of T7 or SP6 polymerase (and using a fixed amount of transcriptionally active amplicon), it appeared as though the T7 RNA polymerase was as effective as SP6 when 30 or 40 units of polymerase were used (Fig. A.3). These observations suggested that when the amount of polymerase is limiting (i.e., when only 10 to 20 units are used), transcription yields may be superior for the SP6 system, perhaps due to a faster rate of polymerase binding and initiation for the SP6 RNA polymerase. The T7 system provided favourable transcription yields when 30 to 40 units of polymerase were used, and due to the much reduced cost of this polymerase compared to SP6, and to the greater commercial availability of this enzyme (compared to SP6), the T7 system was chosen for all subsequent experiments. 


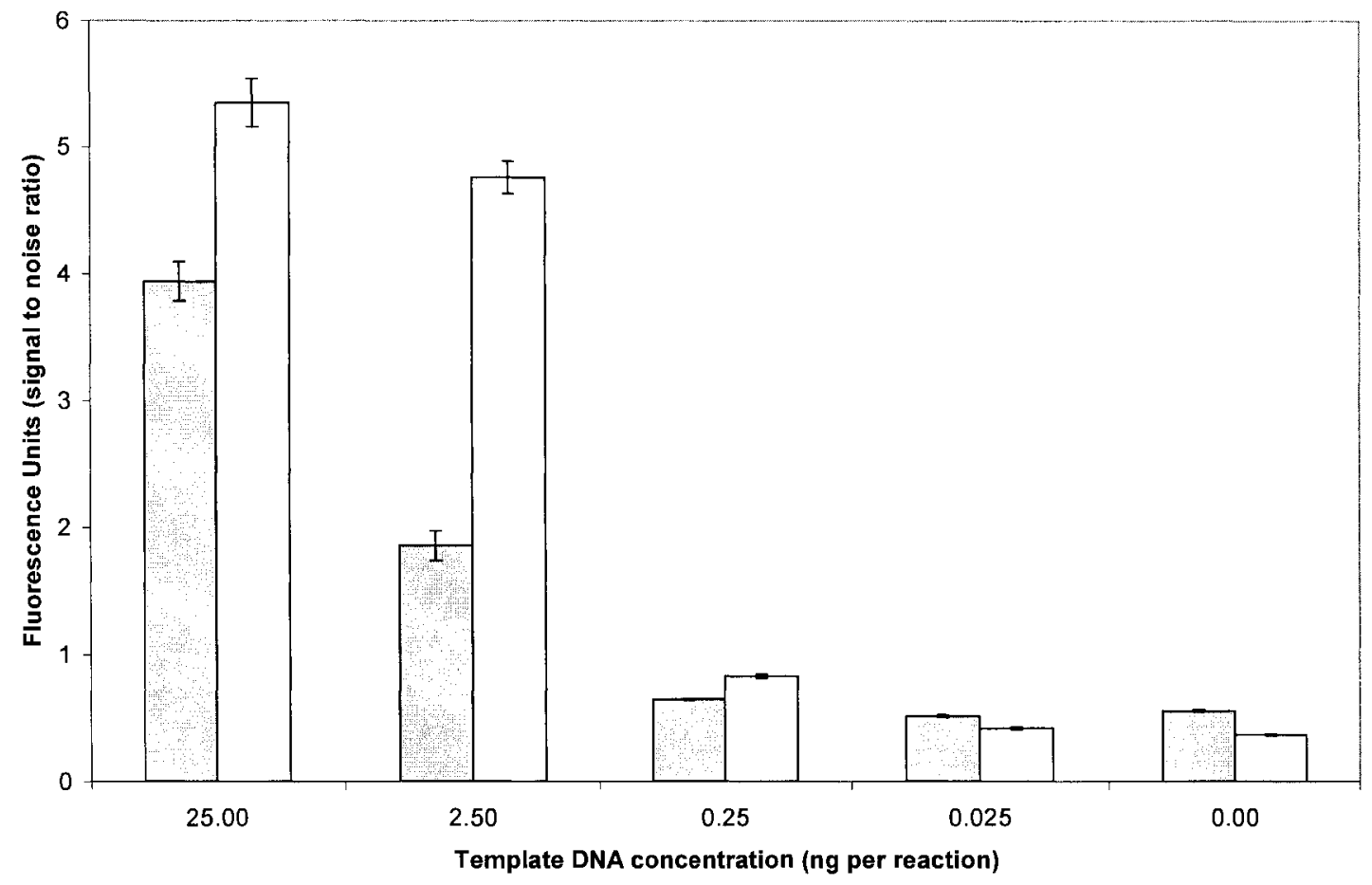

Figure A.2. Comparison of fluorescence intensities obtained by subjecting different amounts of purified 216-bp (T7-35S-1,2) or 218-bp (SP6-35S-1,2) transcriptionally active PCR amplicon to an in vitro transcription reaction mixture containing 10 units of T7 or SP6 RNA polymerase and a 1:20,000 dilution of the fluorescent dye SYBR Green II followed by scanning with a fluorescence plate reader fitted with a $485 / 518 \mathrm{~nm}$ filter set. Fluorescence intensity is expressed as signal to noise ratios \pm the standard deviation $(n=3)$. Signal to noise ratios were calculated by dividing the fluorescence signal obtained from wells containing the polymerase (TRM $+10 \mathrm{U}$ polymerase $+\mathrm{x} n \mathrm{DNA}$ ) by the fluorescence signal obtained from wells without the polymerase added (TRM $+x$ ng DNA). Shaded bars, transcription using T7 RNA polymerase; Non-shaded bars, transcription using SP6 RNA polymerase 


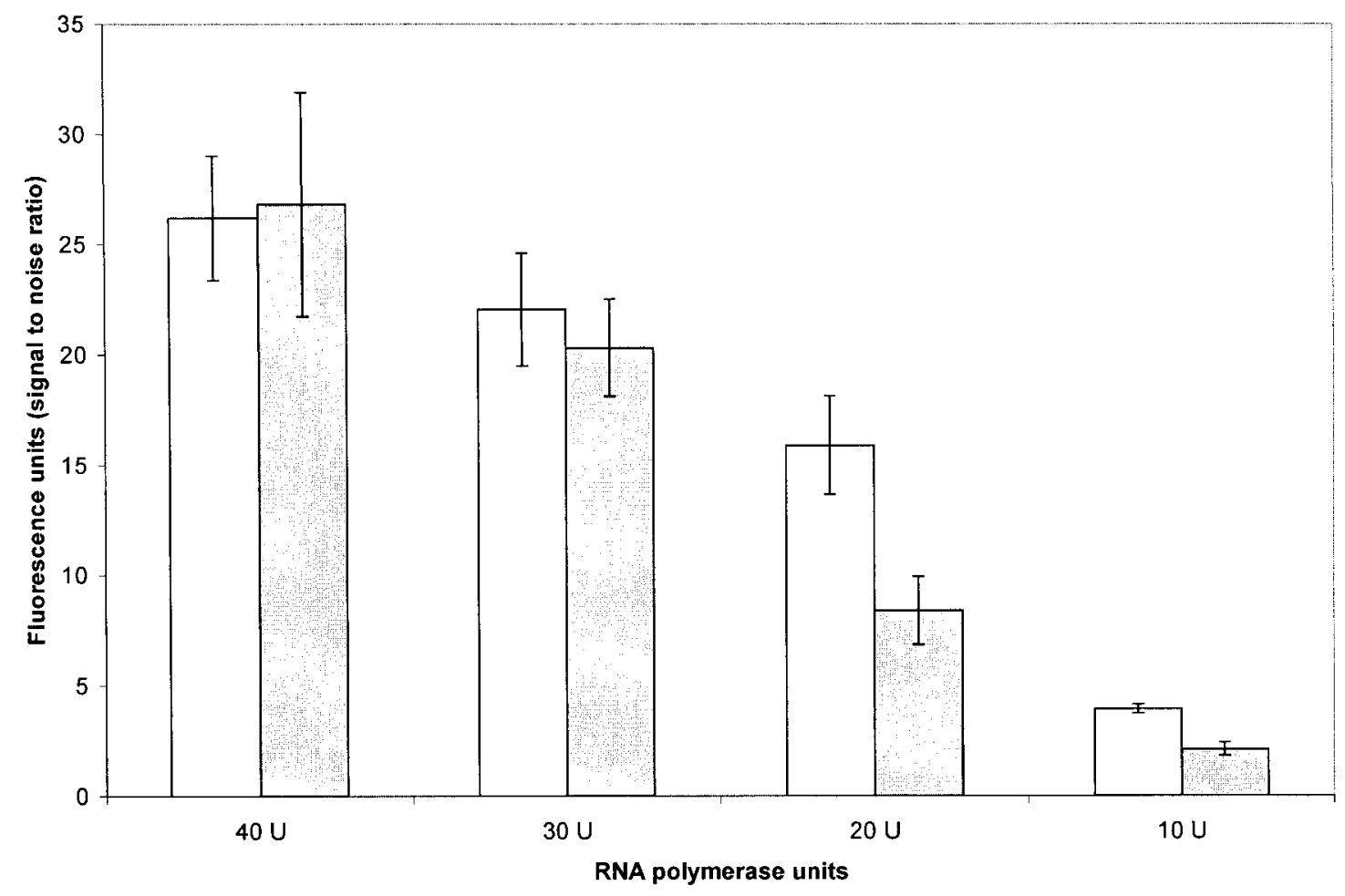

Figure A.3. Comparison of fluorescence intensities obtained by subjecting $10 \mathrm{ng}$ of purified 216-bp (T7-35S-1,2) or 218-bp (SP6-35S-1,2) transcriptionally active PCR amplicon, or $10 \mathrm{ng}$ of purified 195-bp (35S-1,2) non-transcriptionally active PCR amplicon (to be used as the negative control) to an in vitro transcription reaction mixture containing 10 to 40 units of T7 or SP6 RNA polymerase and a 1:20,000 dilution of the fluorescent dye SYBR Green II followed by scanning with a fluorescence plate reader fitted with a $485 / 518 \mathrm{~nm}$ filter set. Fluorescence intensity is expressed as signal to noise ratios \pm the standard deviation $(\mathrm{n}=3)$. Signal to noise ratios were calculated by dividing the fluorescence signal obtained from wells containing $10 \mathrm{ng}$ of transcriptionally active amplicon by the fluorescence signal obtained from wells containing $10 \mathrm{ng}$ of amplicon lacking a functional promoter region. Shaded bars, transcription using T7 RNA polymerase; Non-shaded bars, transcription using SP6 RNA polymerase. 
As a final measure of assay performance prior to the development of the ImmunoScript assay, different quantities of purified, transcriptionally active amplicon (T7-35S-1,2) were subjected to the in vitro transcription reaction using 30 units of T7 RNA polymerase and a 2-hr transcription time (Fig. A.4). These transcription conditions enabled the detection of RNA transcribed from as little as $0.3 \mathrm{ng}$ of starting template (this quantity of DNA was the lowest amount of template required to yield signal to noise ratios $\geq 2$ ). These optimized transcription conditions were utilized for the development of the ImmunoScript assay. 


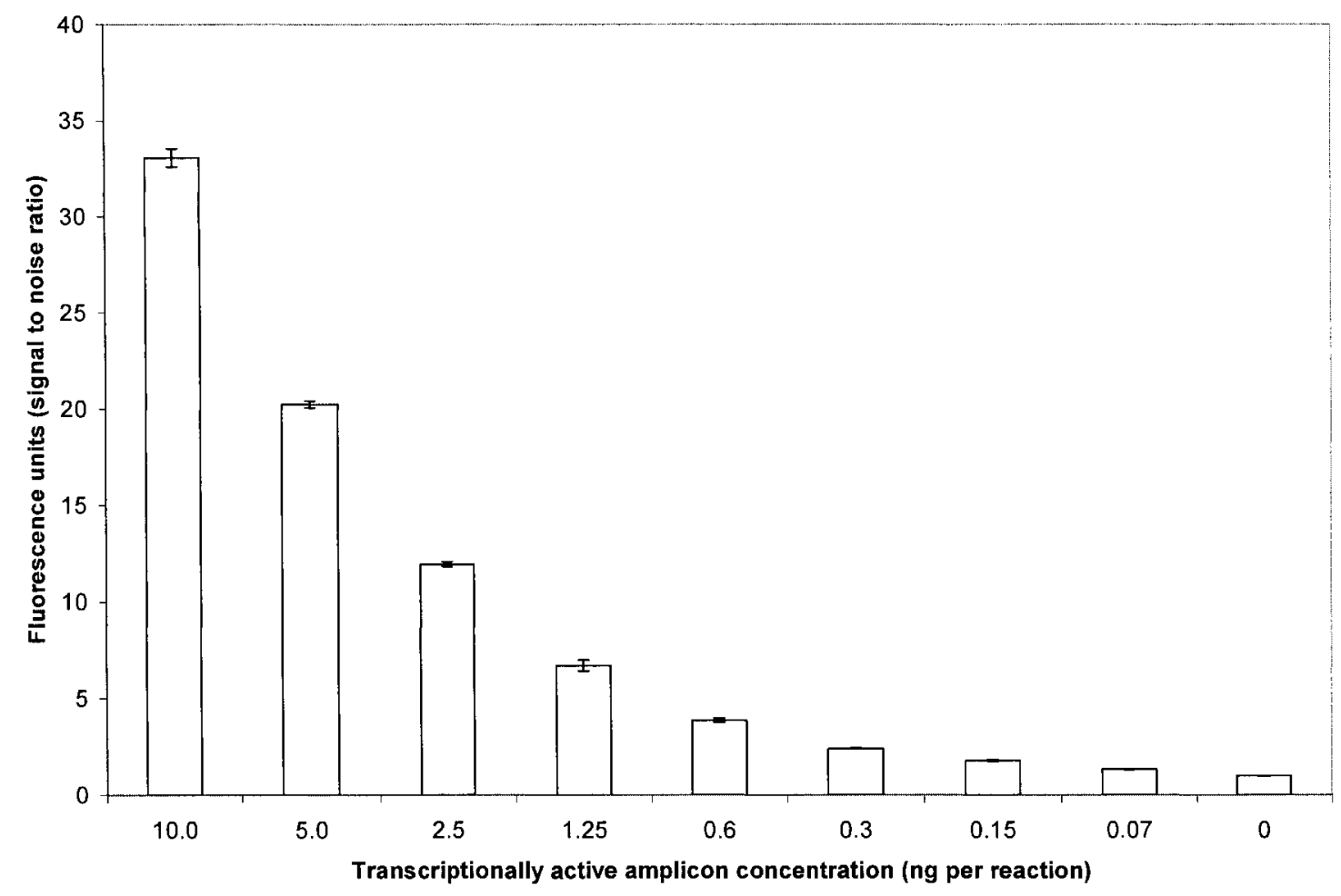

Figure A.4. Detection of RNA transcribed from different quantities of purified 216-bp (T7-35S-1,2) transcriptionally active PCR amplicon subjected to an in vitro transcription reaction mixture containing 30 units of T7 RNA polymerase and a 1:20,000 dilution of the fluorescent dye SYBR Green II followed by scanning with a fluorescence plate reader fitted with a $485 / 518 \mathrm{~nm}$ filter set. Following a 2-hour incubation at $37^{\circ} \mathrm{C}$, the fluorescence was measured at $485 / 518 \mathrm{~nm}$. Fluorescence intensity is expressed as signal to noise ratios \pm the standard deviation $(n=3)$. Signal to noise ratios were calculated by dividing the average fluorescence signal obtained from samples containing different amounts of transcriptionally active amplicon by the average fluorescence signal obtained from the samples containing no template TDNA. 
Development of the ImmunoScript Assay. The development of an ultrasensitive assay system employing a synthetic transcribable DNA fragment as an indicator molecule to label antibodies for enzyme immunoassay applications was attempted using chicken IgY as a model antigenic analyte. The wells of a microtiter plate were coated with commercially available anti-chicken $\operatorname{IgY}$ to capture chicken $\operatorname{IgY}$ (the analyte of interest) followed by reaction with biotinylated anti-chicken IgY. A biotinylated, transcriptionally active DNA fragment was linked to the biotinylated-antichicken $\operatorname{Ig} \mathrm{Y}$ via a streptavidin bridge, and the bound amplicon detected by the addition of a transcription reaction mixture (TRM) using the conditions described above. The optimized transcription conditions for use in the ImmunoScript assay were determined empirically, and it appeared as though utilization of 80 units of T7 RNA polymerase in the transcription reaction mixture produced stronger signals than 30 units. Additionally, the detection sensitivity of the ImmunoScript assay was further improved by increasing the transcription time from 2-hours to 3-hours.

The detectability (in terms of the lowest amount of analyte required to yield signal to noise ratios $\geq 2$ ) of the optimized ImmunoScript assay was compared to that of a traditional sandwich ELISA, which utilized peroxidase-labelled streptavidin with detection using the substrate $3,3^{\prime}, 5,5^{\prime}$-tetramethylbenzidine (TMB). While the ImmunoScript assay exhibited a sensitive dose-response characteristic, the detection sensitivity, or detectability was between 1 to $10 \mathrm{ng}$ per well, compared to 0.1 to $1 \mathrm{ng} /$ well for the traditional sandwich ELISA (Fig. A.5). Similar results were obtained when the fluorogenic substrate Amplex Red was used in place of TMB (not shown). 


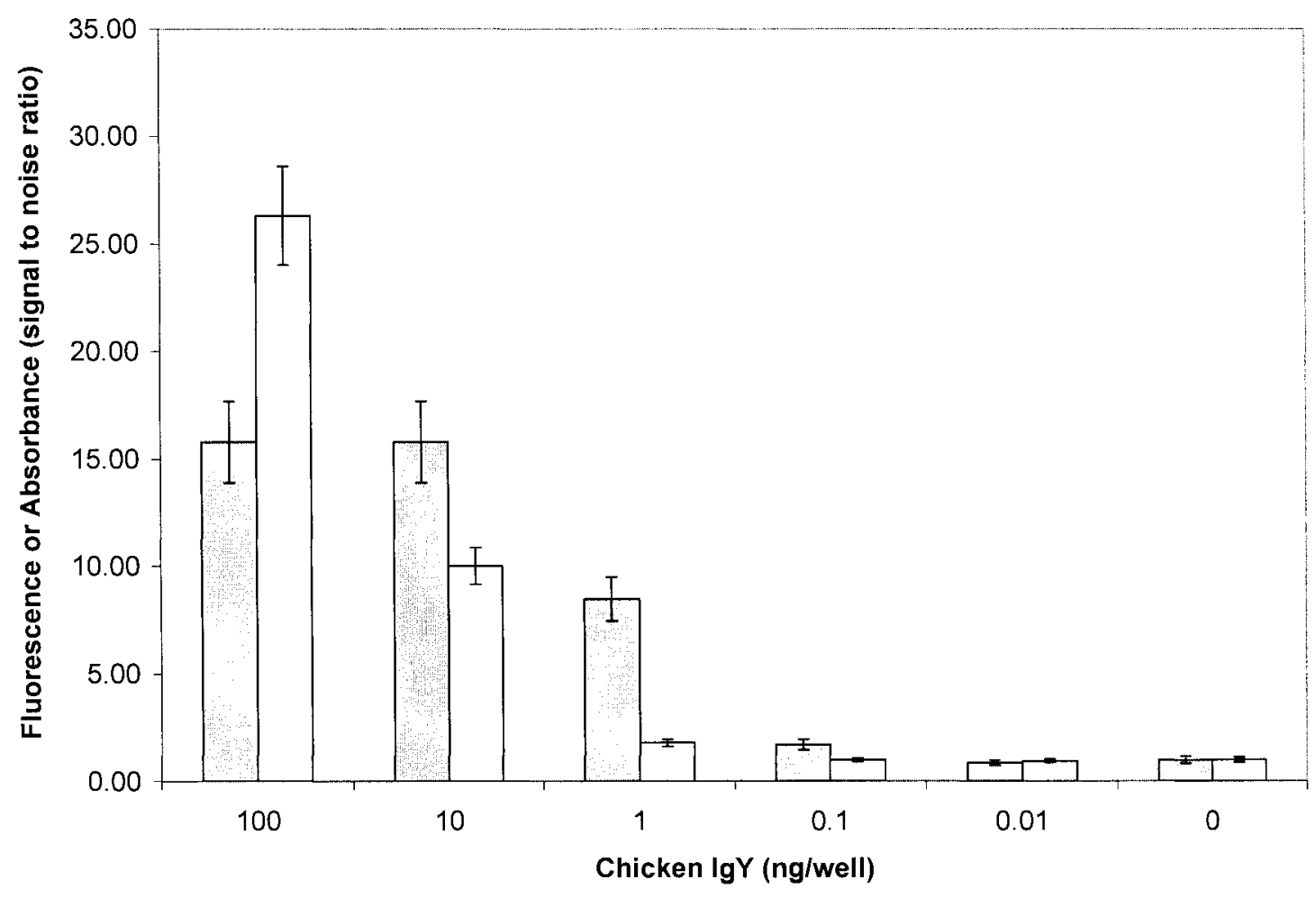

Figure A.5. Comparison of the detection sensitivity of the ImmunoScript Assay to a traditional sandwich ELISA using a chicken IgY-anti-chicken IgY model system. Results are expressed as mean fluorescence signal to noise ratios \pm standard deviation $(n=3)$. Shaded bars, traditional sandwich ELISA; Non-shaded bars, ImmunoScript Assay 
The ImmunoScript assay utilizes an in vitro transcription reaction for the generation of multiple RNA transcripts from a transcribable DNA fragment as an indicator molecule to label antibodies for enzyme immunoassay applications. However, in this reaction the transcription of RNA proceeds in a linear fashion, since the transcribed RNA fragments do not serve as template in subsequent rounds of transcription. As a possible means to improve the detectability of the ImmunoScript assay, the development of Immuno-NASBA was attempted.

Development Immuno-NASBA. As a possible means to boost the detection sensitivity of the ImmunoScript assay, the use of an alternative RNA amplification mechanism was attempted. Nucleic acid sequence-based amplification (NASBA) is an isothermal nucleic acid amplification technique that utilizes three enzymes (AMV Reverse Transcriptase, RNase H, and T7 or SP6 RNA polymerase) in addition to two primer sequences (one of which bears the RNA polymerase promoter sequence) to exponentially amplify RNA or DNA targets in vitro (Compton, 1991). In NASBA, unlike in vitro transcription, the transcribed RNA fragments are utilized as template in subsequent cycles of the NASBA reaction, resulting in exponential (rather than simply linear) amplification of RNA (Fig. A.6). Since the entire process occurs at a single temperature $\left(41^{\circ} \mathrm{C}\right)$, the use of a thermal cycler is not required. 


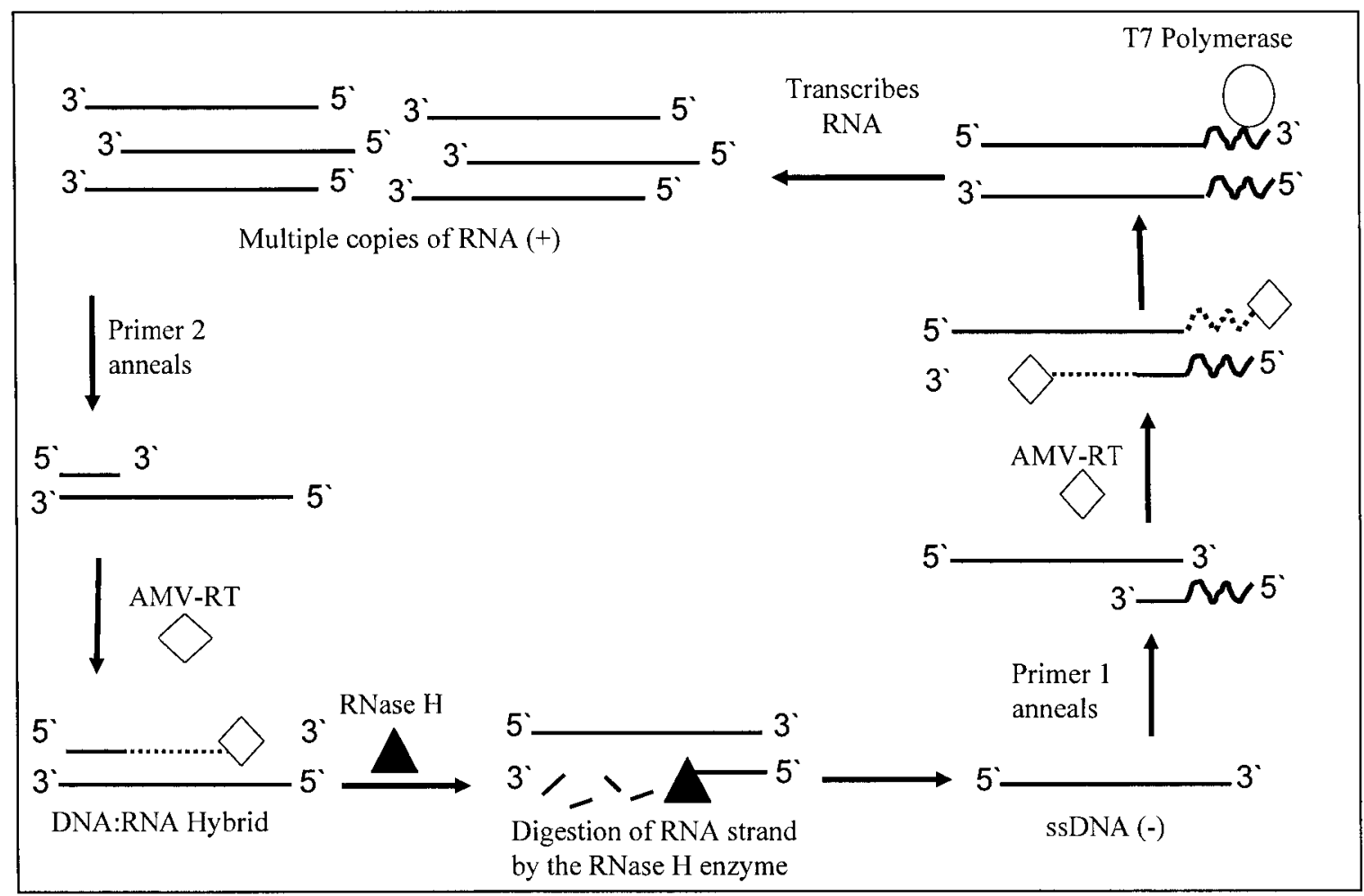

Figure A.6. Schematic representation of the isothermal Nucleic Acid Sequence-Based Amplification (NASBA) reaction. 
Prior to the development of Immuno-NASBA, it was necessary to determine the optimum method for detection of the NASBA products. Therefore, the NASBA reaction was performed on serially diluted amounts of transcriptionally active T7-35S1, 35S-2 starting template. The reaction products from the first NASBA experiments were stained with SYBR Green II dye (as in the ImmunoScript experiments), and it appeared as though staining with this dye was not effective due to high background fluorescence levels (not shown), possibly due to the presence of primers that are present in the NASBA reaction mixture causing high background when using a general purpose singlestranded nucleic acid-binding dye such as SYBR Green II to detect the RNA products. Therefore, the utilization of molecular beacon probes for NASBA product detection was examined. Molecular beacons are hairpin-shaped oligonucleotide probes that possess an internally quenched fluorophore that exhibits fluorescence only upon hybridization to a target nucleic acid (Tyagi and Kramer, 1996). The loop portion of the hairpin is the probe sequence of the beacon that is designed to bind to a complementary sequence in the target nucleic acid, while the stem portion of the hairpin keeps the fluorophore in close proximity to the quencher moiety, thereby quenching fluorescence until hybridization occurs. In the presence of a nucleic acid sequence complementary to the loop portion, it becomes more energetically favourable for the loop portion to bind to its target so that the stem portion is forced to open up and fluorescence is restored (Tyagi and Kramer, 1996).

The detection of the NASBA products using molecular beacon probe technology was performed on products that were heated for $2-\mathrm{min}$ at $100^{\circ} \mathrm{C}$ to deactivate the RNase 
H enzyme, which may have degraded the RNA strand of the RNA:Molecular Beacon hybrid, and on products that did not receive any heat treatment (Fig. A.7). Additionally, the detection of RNA transcribed using the linear, in vitro transcription reaction was compared to the detection of the NASBA products using molecular beacon probes. Heat treatment of the NASBA product mixture (to deactivate the RNase H enzyme) prior to the addition of the molecular beacon probe did not appear to have any impact on the detectability of the assay. Use of molecular beacon probes for the detection of RNA transcribed from varying amounts of starting template enabled the detection of RNA transcribed from approximately $1.0 \mathrm{ng}$ of starting template, for the both the NASBA reaction and transcription reaction products.

It seemed unusual that the detection sensitivity was not improved using the NASBA reaction, as this reaction should exponentially amplify RNA from a transcriptionally active DNA template, rather than in a simply linear fashion as in transcription alone. Therefore, the detection sensitivity of the NASBA and transcription reactions was further analyzed by heating their reaction products in the presence of 1.0 $\mu \mathrm{M}$ of molecular beacon probe, followed by slow cooling to room temperature (Fig. A.8). Upon comparison of Figures A.7 and A.8, it appeared as though it was necessary to heat the products in the presence of the molecular beacon probe, followed by cooling to room temperature, to facilitate effective detection of the reaction products. In this manner, utilization of the molecular beacon probes enabled the detection of NASBA product from only $0.01 \mathrm{ng}$ of template DNA, compared to $1.0 \mathrm{ng}$ of starting template DNA for the product of transcription alone (Fig. A.8). 


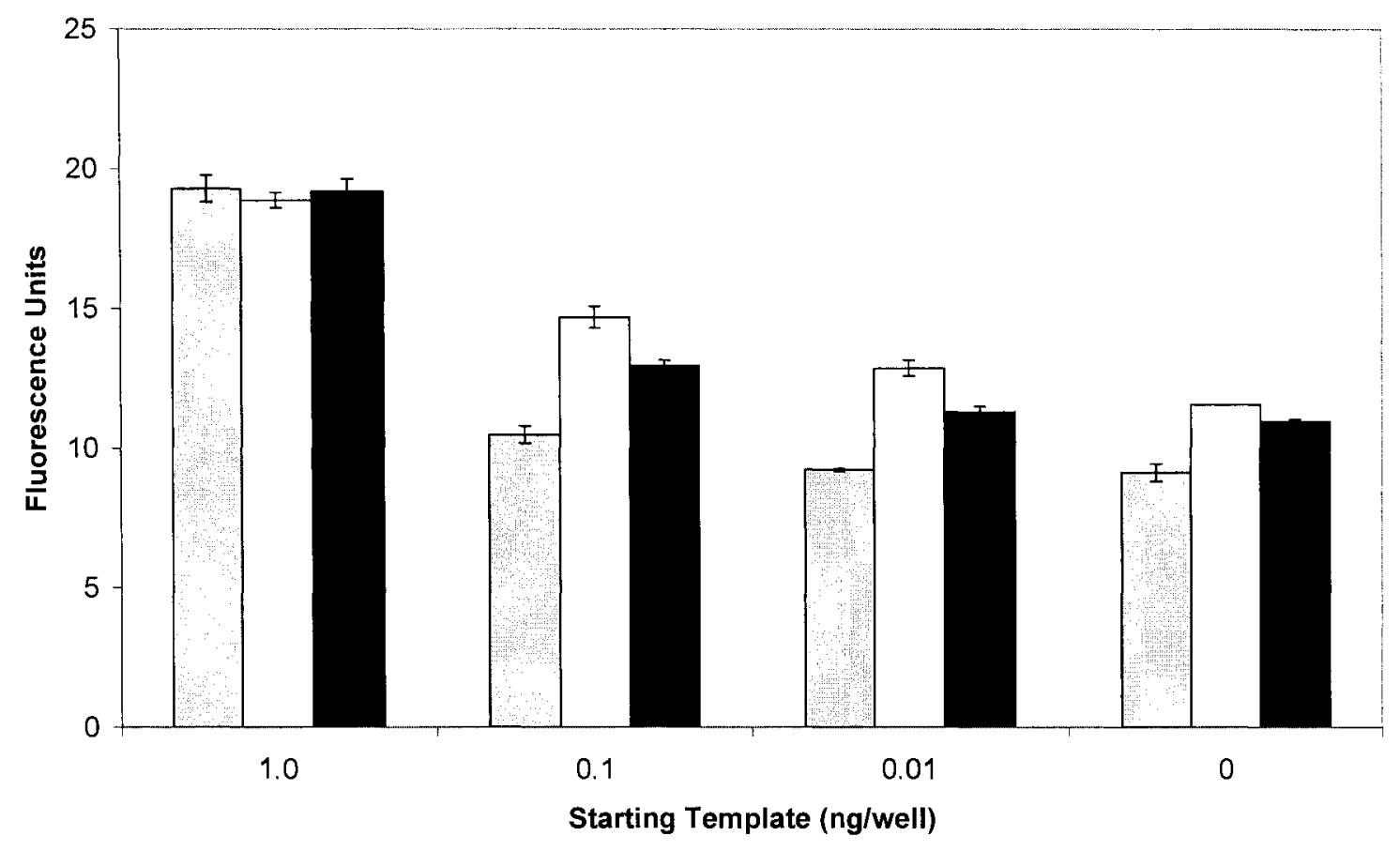

Figure A.7. Detection of transcription and NASBA reaction products from different concentrations of starting template using molecular beacon probe technology. Detectability of the reaction products was examined for the products of transcription alone (grey bars), on NASBA products that were heated for $2-\mathrm{min}$ at $100^{\circ} \mathrm{C}$ to deactivate the RNase $\mathrm{H}$ enzyme (black bars), and on NASBA reaction products that did not receive any heat treatment (white bars) following 30-min hybridization with a $1.0 \mu \mathrm{M}$ solution of molecular beacon probe. Results are expressed as mean fluorescence signal \pm standard deviation $(n=3)$. 


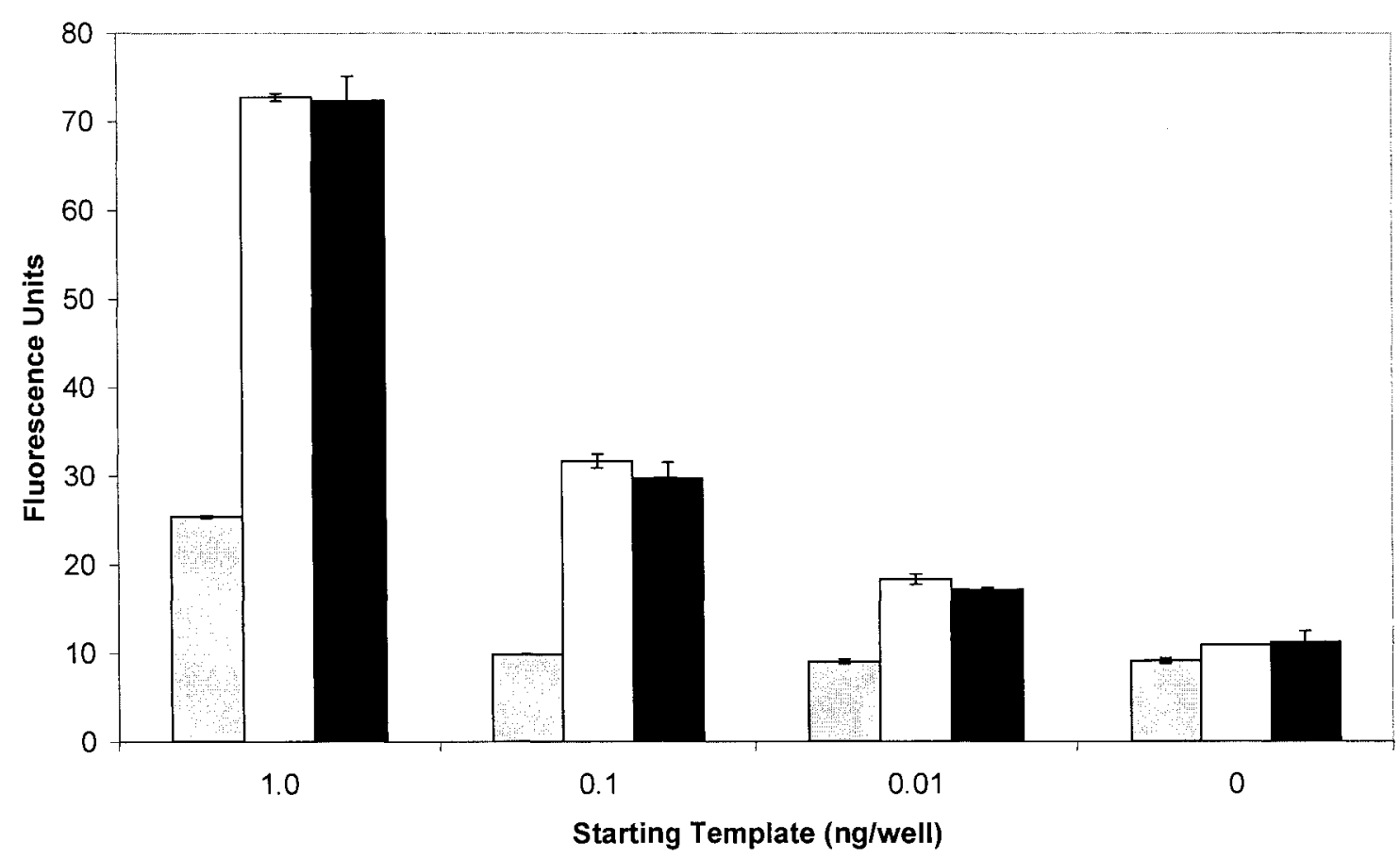

Figure A.8. Detection of transcription and NASBA reaction products from different concentrations of starting template after heating the reaction products with a $1.0 \mu \mathrm{M}$ solution of molecular beacon probe followed by slow cooling for 30-min. Detectability of the reaction products was examined for the products of transcription alone (grey bars), on NASBA products that were heated for $2-\mathrm{min}$ at $100^{\circ} \mathrm{C}$ to deactivate the RNase $\mathrm{H}$ enzyme (black bars), and on NASBA reaction products that did not receive any heat treatment to deactivate the RNase $\mathrm{H}$ enzyme (white bars). Results are expressed as mean fluorescence signal \pm standard deviation $(n=3)$. 
The observation that heat treatment of the NASBA product in the presence of the molecular beacon was necessary to enable effective detection prompted investigations as to the possible secondary structure of the RNA transcript that was transcribed from the PCR-generated TDNA fragment, as extensive secondary structure of the RNA transcript may hinder hybridization by the molecular beacon probe. Using DNAMan sequence analysis software (Lynnon BioSoft, Vaudreuil-Dorion, QC, Canada), the estimated secondary structure of the RNA transcript was analyzed (Fig. A.9). 


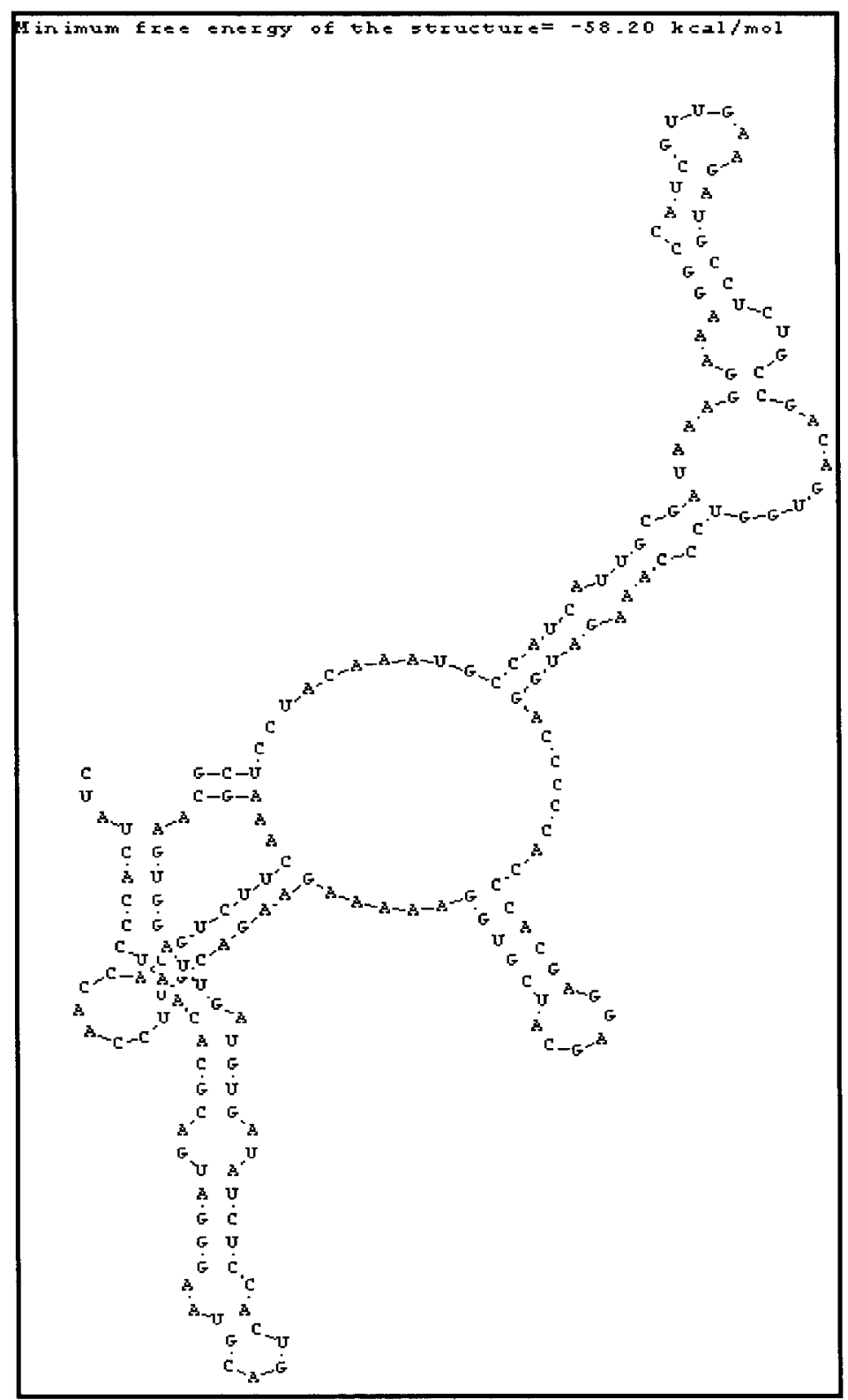

Figure A.9. Estimated secondary structure and free energy of the RNA fragment transcribed from the $216 \mathrm{bp}$ - promoter appended amplicon from the $35 \mathrm{~S}$ region of Roundup Ready soy DNA (prepared by PCR synthesis using primer set T7-35S-1, 35S-2 as described in Methods) predicted using DNA Man nucleic acid analysis software. 
The estimated RNA structure analysis suggested that the RNA transcript had extensive secondary structure that was quite stable (estimated free energy near -60 $\mathrm{kcal} / \mathrm{mol}$ ). Therefore, as a possible means to improve the effectiveness of hybridization, the length of the promoter-appended amplicon prepared by PCR synthesis from the $35 \mathrm{~S}$ promoter region of RR soy was shortened (by replacing the reverse primer used during PCR synthesis as described in Methods) to yield an RNA transcript with less extensive secondary structure, as estimated by the nucleic acid analysis software (Fig. A.10).

When this shortened TDNA fragment was used as template in the NASBA reaction, molecular beacon probe hybridization enabled the detection of NASBA product from between 1.0 to $0.1 \mathrm{pg}$ of starting template, without the need for a heating step to enable effective hybridization of the probe to the NASBA product (Fig. A.11). In comparison, the optimized in vitro transcription conditions enabled the detection of RNA transcribed from approximately $0.3 \mathrm{ng}$ of starting template when using SYBR Green II stain to detect the RNA transcripts (Fig. A.4), or from $1.0 \mathrm{ng}$ of starting template when molecular beacon probe technology was used for transcript detection (Fig. A.8). The increased detection sensitivity of the NASBA reaction with molecular beacon probe technology for transcript detection suggested that the detection sensitivity of the ImmunoScript assay could be increased through the utilization NASBA as the RNA amplification mechanism (in place of in vitro transcription) for the development of Immuno-NASBA. 


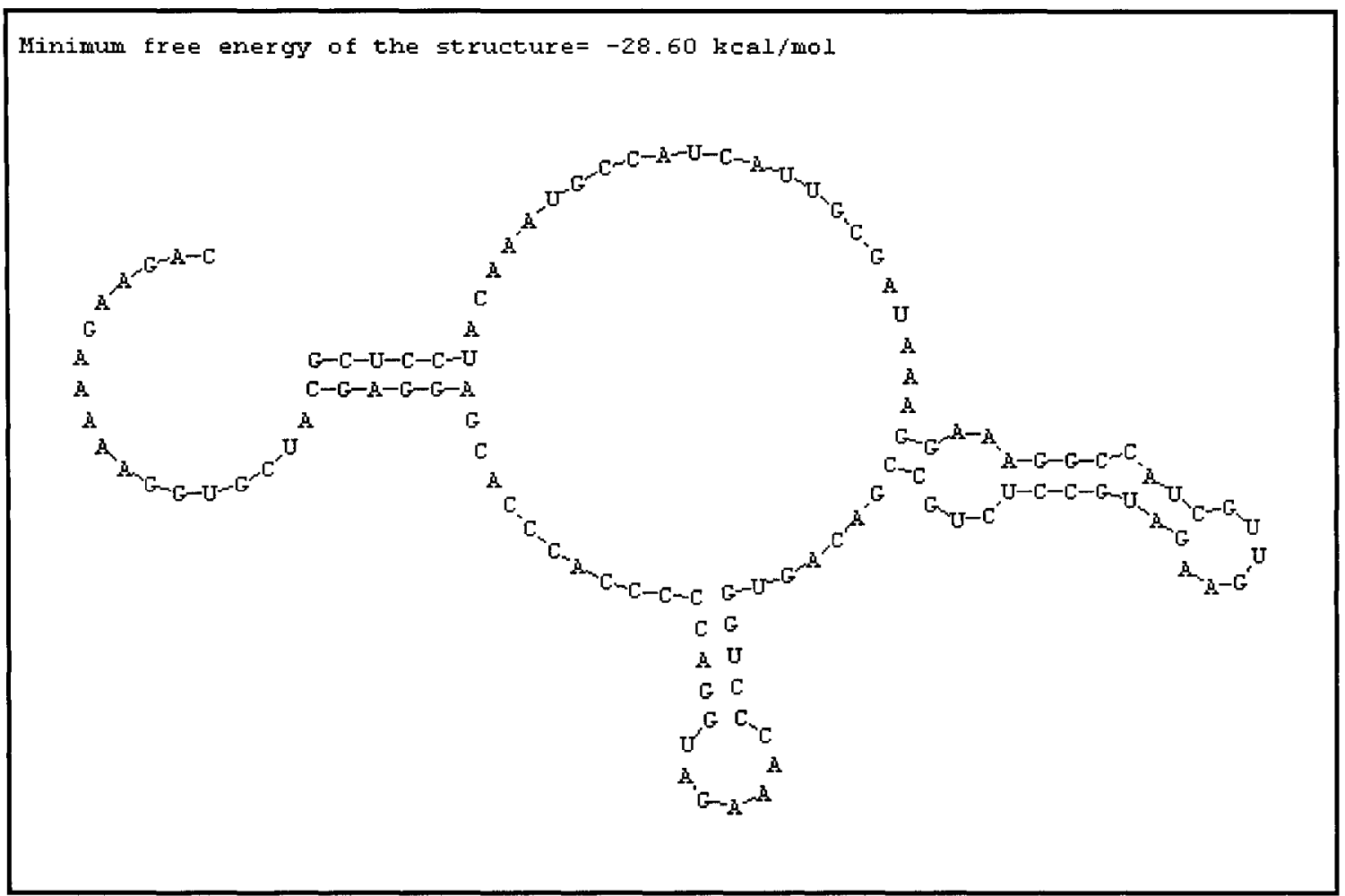

Figure A.10. Estimated secondary structure of the RNA fragment transcribed from the shortened, $137 \mathrm{bp}$, promoter-appended amplicon from the 35S region of Roundup Ready soy DNA (prepared by PCR synthesis using primer set T7-35S-1, 35S-5 as described in Methods) predicted using DNA Man nucleic acid analysis software. 


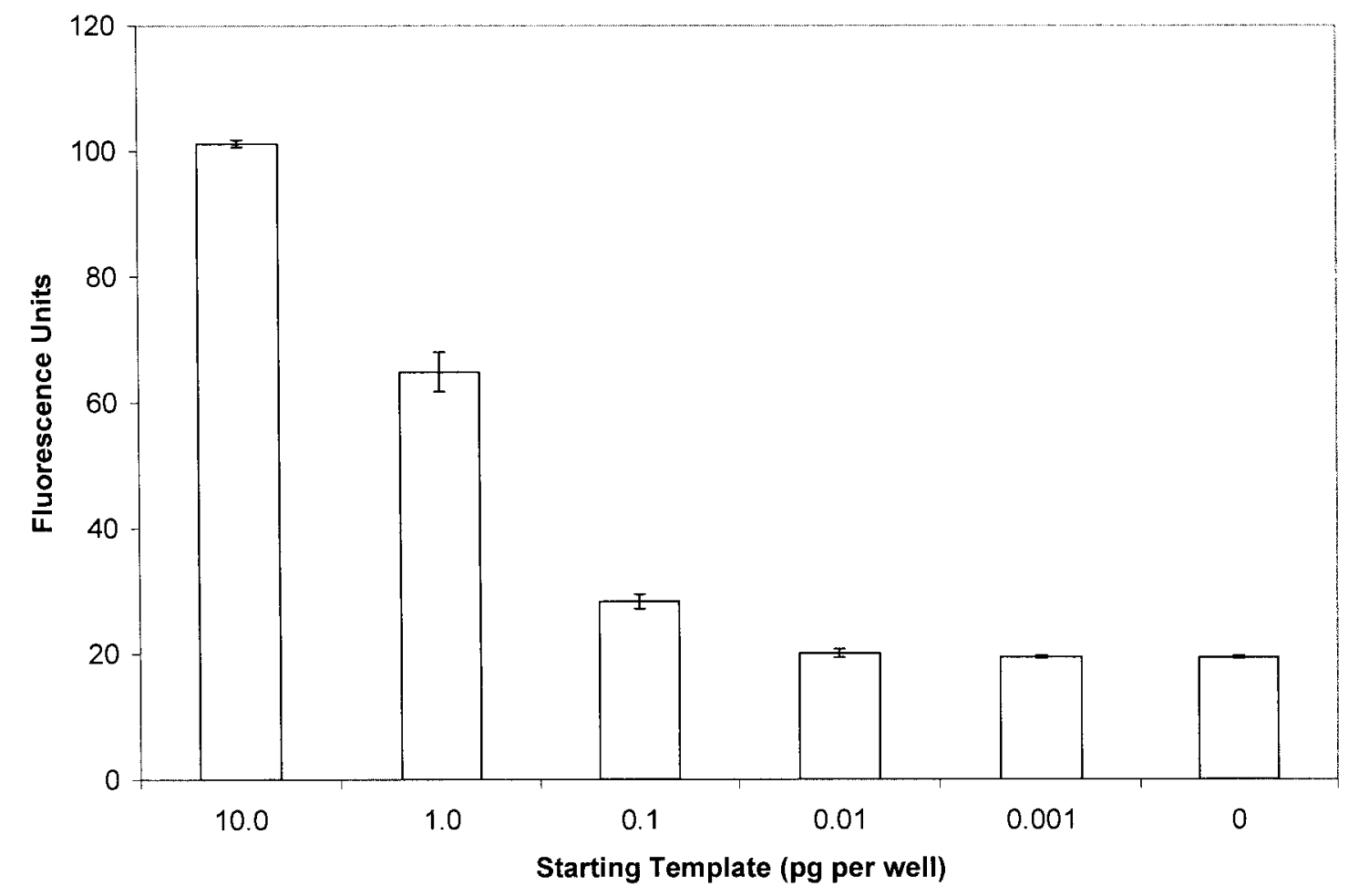

Figure A.11. Detection of NASBA reaction products from different concentrations of the shortened $137 \mathrm{bp}$-T7 RNA promoter appended amplicon using molecular beacon probe technology. Detectability of the reaction products was examined following 30-min hybridization with a $1.0 \mu \mathrm{M}$ solution of molecular beacon probe. Results are expressed as mean fluorescence signal \pm standard deviation $(\mathrm{n}=3)$. 
The shortened, single-stranded RNA product appeared to efficiently hybridize to the molecular beacon probe without a prior denaturation step. Use of this shortened fragment should enable the performance of the assay as a closed tube system, which would alleviate the need for a post-amplification handling step for detection of the product, thus minimizing the risk of contamination. This shortened, biotinylated, transcriptionally active DNA fragment was therefore used as the indicator molecule to be conjugated to the biotinylated anti-chicken IgY via a streptavidin bridge in ImmunoNASBA.

Performance of the Immuno-NASBA reaction using the shortened TDNA fragment and detection using molecular beacon probe hybridization resulted in high fluorescence values for all reactions, regardless of whether any target analyte was present (not shown). This was possibly due to non-specific binding of the biotinylated TDNA fragment to the wells of the microtiter plate, or perhaps due to non-specific binding of streptavidin to the wells, which would in turn capture biotinylated TDNA molecules thus generating NASBA products that were detectable by molecular beacon hybridization. To examine this possibility, the concentration of streptavidin used to conjugate the biotinylated TDNA fragment to the biotinylated detector antibody was examined. It appeared as though even the most dilute streptavidin solution $(0.1 \mathrm{ng} / \mu \mathrm{l})$ caused nonspecific binding of the biotinylated amplicon (Fig. A.12). 


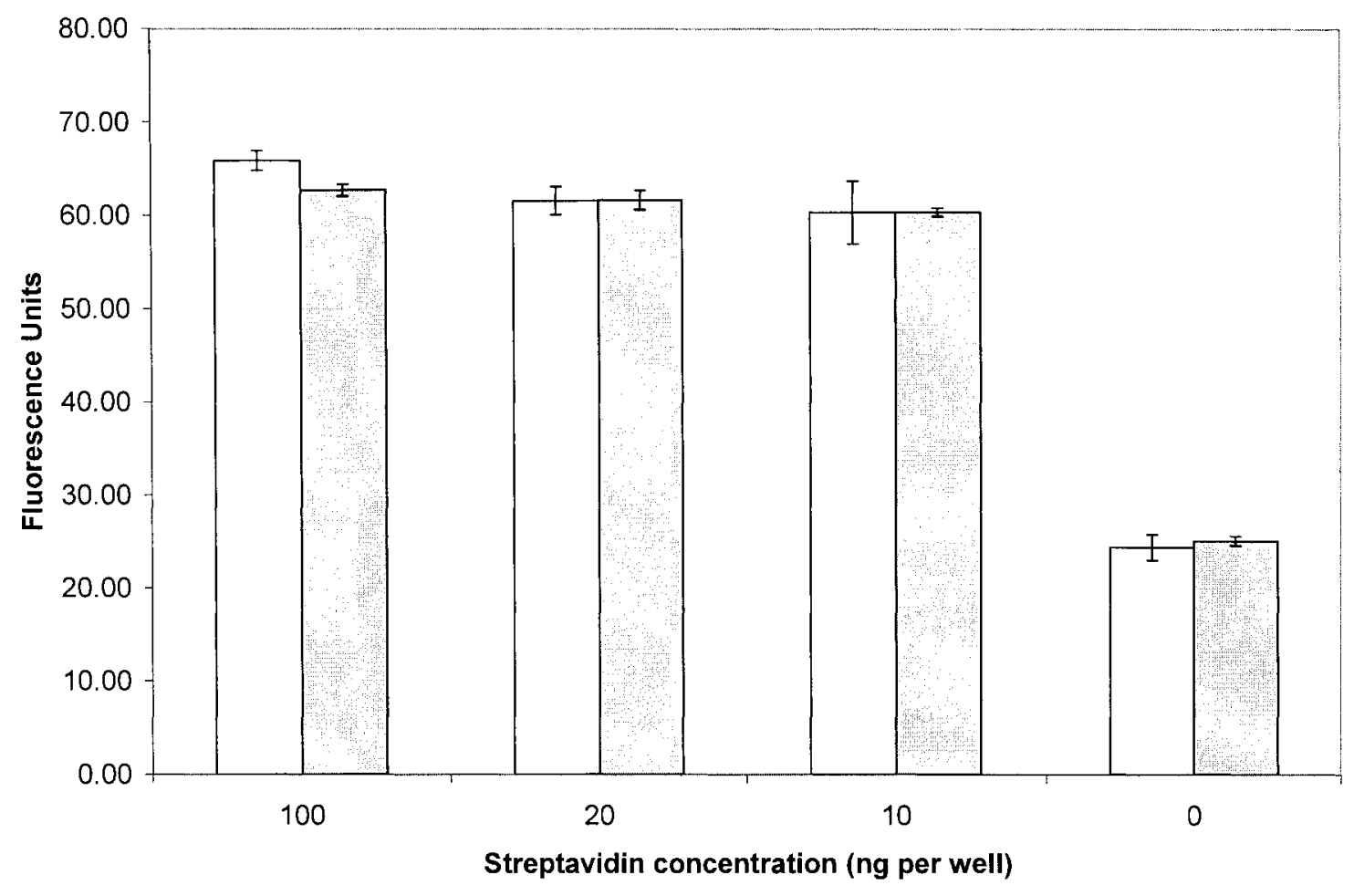

Figure A.12. Optimization of streptavidin concentration used to link the transcriptionally active DNA fragment to the biotinylated anti-chicken IgY antibody in the performance of the Immuno-NASBA assay using the shortened TDNA fragment and RNA transcript detection using molecular beacon probe hybridization. Results are expressed as mean fluorescence signal \pm standard deviation $(\mathrm{n}=3)$. White bars, $1 \mathrm{ng}$ chicken IgY target analyte; Grey bars, 0 ng chicken IgY target analyte. 
The streptavidin bridge method of linking the transcriptionally active DNA (TDNA) fragment to the antibody does not appear to be effective, as it does not allow for discrimination between positive and negative reactions. Future experiments will need to be performed to examine alternative means of conjugating the TDNA fragment to the detector antibody. Generation of a 5'-aminated transcriptionally active amplicon by PCR (by using a 5'-aminated reverse primer in place of the biotinylated primer) should allow for direct conjugation of the TDNA fragment to the anti-chicken IgY via covalent linkage through either glutaraldehyde treatment or through periodate oxidation. This would alleviate the need for a streptavidin bridge to link the transcriptionally active DNA fragment to the biotinylated antibody, avoiding non-specific binding of any streptavidin to the microtiter plate wells that could capture biotinylated TDNA molecules that appeared to cause false positives in the Immuno-NASBA system. Direct conjugation of the TDNA fragment to the detector antibody would also result in a reduction in the number of wash steps compared to the biotin-streptavidin method of linking the TDNA to the antibody, possibly boosting the sensitivity of the Immuno-NASBA (or ImmunoScript) assays.

The identification of optimized in vitro transcription conditions using a synthetic transcribable DNA fragment with a defined sequence of nucleotides corresponding to the $\mathrm{T} 7$ promoter region, in addition to an effective means for detecting the reaction products using the fluorescent dye SYBR Green II, may provide useful information to other investigators developing methods based on in vitro transcription reactions, such as the 
development of RNA probes for blotting applications, or in situ hybridization experiments, or for use in antisense RNA studies.

The development of more rapid and sensitive assays will assist in ensuring the safety of the food supply for consumers, while enabling the rapid release of contaminantfree foods back onto the market prior to their expiry date, thus minimizing any unnecessary financial loss to food producers. Furthermore, the development of new technologies will provide regulatory laboratories with the enhanced capability to deal with challenging sample matrices. The development of the assay systems described in this appendix have the potential to be of use over a broad spectrum of different applications, and may prove useful to other investigators seeking to detect trace analytes, such as cellular metabolites, and environmental contaminants or pollutants. 


\section{References}


Abdulmawjood, A., S. Roth, and M. Bulte. (2002) Two methods for construction of internal amplification controls for the detection of Escherichia coli $\mathrm{O} 157$ by polymerase chain reaction. Mol. Cell. Probes 16:335-339.

AGBIOS. (2006) GM Database. AGBIOS, Merrickville, ON. http://www.agbios.com/dbase.php/ (12 July 2006)

Ahn S.J., J. Costa, and J. Rettig Emanuel. (1996) PicoGreen quantitation of DNA: effective evaluation of samples pre- or post-PCR. Nucleic Acids Res. 24:26232625

Akiyama, H., K. Sugimoto, M. Matsumoto, K. Isuzugawa, M. Shibuya, Y. Goda, and M. Toyoda. (2002) A detection method of recombinant DNA from genetically modified potato (NewLeaf Plus potato) and detection of NewLeaf Plus potato in snack. Shokuhin Eiseigaku Zasshi 43:24-29

Armour, J. and B.W. Blais. (2006) Cloth-Based Hybridization Array System for the Detection and Identification of Ruminant Species in Animal Feed. J. Food Protection 69:453-458

BATS. (2003) Genetically modified (GM) crops: Molecular and regulatory details. http://www.bats.ch/bats/en/index.php (30 June 2003) 
Bauer, T., P. Weller, W.P. Hammes, and C. Hertel. (2003) The effect of processing parameters on DNA degradation in food. Eur. Food Res. Technol. 217:338-343

Baumgartner, S., I. Steiner, S. Kloiber, D. Hirmann, R. Krska, and J. Yeung. (2002) Towards the development of a dipstick immunoassay for the detection of trace amounts of egg proteins in food. Eur. Food. Res. Technol. 214:168-170

Berdal, K.G. and A. Holst-Jensen. (2001) RoundUp Ready soybean event-specific realtime quantitative PCR assay and estimation of the practical detection and quantification limits in GMO analysis. Eur. Food Res. Technol. 213:432-438

Blais, B.W., H. Yamazaki, and C. Rigby. (1989) Use of hydrophobic cloths as antibody adsorbents for enzyme immunoassay: Detection of Brucella antigens. Vet. Microbiol. 20:155-163

Blais, B.W. (1994) Transcriptional enhancement of the Listeria monocytogenes PCR and simple immunoenzymatic detection using anti-RNA:DNA antibodies. Appl. Environ. Micrbiol. 60:348-352

Blais, B.W. and L.M. Phillippe. (1995) Macroporous hydrophobic cloth (polymacron) as a solid phase for nucleic acid probe hybridizations. Biotech. Tech. 9:377-382 
Blais, B.W., L.M. Phillippe, and N. Vary. (2002) Cloth-based hybridization array system for detection of transgenic soy and corn by multiplex polymerase chain reaction. Biotechnol. Letters 24:1407-1411.

Blais, B.W., M. Gaudreault, and L.M. Phillippe. (2003) Multiplex enzyme immunoassay system for the simultaneous detection of multiple allergens in foods. Food Control 14:43-47

Canadian Food Inspection Agency. (2002) Decision Document DD2002-40. Determination of the safety of BASF's Imazethapyr tolerant (CLEARFIELD ${ }^{\mathrm{TM}}$ ) rice. http://www.inspection.gc.ca (19 June 2006)

Canadian Food Inspection Agency. (2004) International activity on the labelling of foods derived from biotechnology. http://www.inspection.gc.ca (19 June 2006)

Canadian Food Inspection Agency. (2006) Developing a Canadian standard for the voluntary labelling of foods derived through biotechnology. http://www.inspection.gc.ca (19 June 2006)

Cesarone C.F., C. Bolongnesi, and L. Santi. (1979) Improved microfluorometric DNA determination in biological material using 33258 Hoechst. Anal. Biochem. 100:188-197 
Chen, Y., Y. Wang, Y. Ge, and B. Xu. (2005) Degradation of endogenous and exogenous genes of Roundup-Ready soybean during food processing. J. Agric. Food Chem. $53: 10239-10243$

Compton, J. (1991) Nucleic acid sequence-based amplification. Nature (London). $350: 91-92$

Delcenserie, V., N. Bechoux, B. China, G. Daube, and F. Gavini. (2005) A PCR method for detection of bifidobacteria in raw milk and raw milk cheese: comparison with culture-based methods. J. Microbiol. Methods 61:55-67

Diaz, C., C. Fernandez, R. McDonald, and J.M. Yeung. (2002) Determination of Cry9C protein in processed foods made with StarLink corn. J. AOAC Int. 85:1070-1076

EnviroLogix. (2006) EnviroLogix QuantiPlate kit for Cry9C. http://www.envirologix.com/library/ap008insert.pdf (20 July 2006)

Gallagher, S.R. (2004) Quantitation of DNA and RNA with absorption and fluorescence spectroscopy. In: Ausubel FM, Brent R, Kingston RE, Moore DD, Seidman JG, Smith JA, Struhl K, eds. Current Protocols in Molecular Biology, Vol. 5., New York: John Wiley \& Sons, pp. A.3D.1-A.3D.12. 
Gao, M. and R.N. Chibbar. (2000) Isolation, characterization, and expression analysis of starch synthase IIa cDNA from wheat (Triticum aestivum L.). Genome 43:768775

Gauthier, M. and B.W. Blais. (2004) Cloth-based hybridization array system for the detection of multiple antibiotic resistance genes in Salmonella enterica subsp. enterica serotype Typhimurium DT104. Lett. Appl. Microbiol. 38:265-270.

Gauthier, M., B. Cadieux, J.W. Austin, and B.W. Blais. (2005) Cloth-based hybridization array system for the detection of Clostridium botulinum type A, B, E and F neurotoxin genes. J. Food Protection 68:1477-1483.

Germini, A., S. Rossi, A. Zanetti, R. Corradini, C. Fogher, and R. Marchelli. (2005) Development of a peptide nucleic acid array platform for the detection of genetically modified organisms in food. J. Agric. Food Chem. 53:3958-3962

Hardegger, M., P. Brodmann, and A. Herrmann. (1999) Quantitative detection of the 35S promoter and the NOS terminator using quantitative competitive PCR. Eur. Food Res. Technol. 209:83-87

Hassan-Hauser, C., W. Mayer, and H. Hortner. (1998) Detection of the starch modifying gbss-antisense construct in transgenic potatoes. Z. Lebensm. Unters. Forsch. 206:83-87 
Hernandez, M., M. Pla, T. Esteve, S. Prat, P. Puigdomenech, and A. Ferrando. (2003a) A specific real-time quantitative PCR detection system for event MON810 in maize YieldGard based on the 3'-transgene integration sequence. Transgenic Res. 12:179-189

Hernandez, M., D. Rodriguez-Lazaro, T. Esteve, S. Prat and M. Pla. (2003b) Development of melting temperature-based SYBR Green I polymerase chain reaction methods for multiplex genetically modified organism detection. Anal. Biochem. 323:164-170

Iida, M., S. Yamashiro, H. Yamakawa, K. Hayakawa, H. Kuribara, T. Kodama, S. Furui, H. Akiyama, T. Maitani, and A. Hino. (2005) Development of taxon-specific sequences of common wheat for the detection of genetically modified wheat. $J$. Agric. Food Chem. 53:6294-6300

Holst-Jensen, A., S.B. Ronning, A. Lovseth, and K.G. Berdal. (2003) PCR technology for screening and quantification of genetically modified organisms. Anal. Bioanal. Chem. 375:985-993

Inouye, S. and R. Hondo. (1990) Microplate hybridization of amplified viral DNA segment. J. Clin. Microbiol. 28:1469-1472 
James, C. (2005) Executive summary of global status of commercialized biotech/GM crops: 2005. ISAAA Briefs No. 34. ISAAA: Ithaca, NY.

James, D., A-M. Schmidt, E. Wall, M. Green, and S. Masri. (2003) Reliable detection and identification of genetically modified maize, soybean, and canola by multiplex PCR analysis. J. Agric. Food Chem. 51:5829-5834

Jones, R.N., M.L. Neale, B. Beattie, D. Westmoreland, and J.D. Fox. (2000) Development and application of a PCR-based method including an internal control for diagnosis of congenital cytomegalovirus infection. J. Clin. Microbiol. $38: 1-6$

Jorgensen, E.D., R.K. Durbin, S.S. Risman, and W.T. McAllister. (1991) Specific contacts between the bacteriophage T3, T7, and SP6 RNA polymerases and their promoters. J. Biol. Chem. 266:645-651

Labarca, C. and K. Paigen. (1980) A simple, rapid and sensitive DNA assay procedure. Anal. Biochem. 102:344-352

Leggate, J., R. Allain, L. Isaac, and B.W. Blais. (2006) Microplate fluorescence assay for the quantification of double stranded DNA using SYBR green I dye. Biotechnol. Lett. 28:1587-1594 
Leggate, J. and B.W. Blais. (2006) An internal amplification control system based on primer-dimer formation for PCR product detection by DNA hybridization. $J$. Food Protection 69:2280-2284

Leimanis, S., M. Hernandez, S. Fernandez, F. Boyer, M. Burns, S. Bruderer, T. Glouden, N. Harris, O. Kaeppeli, P. Philipp, M. Pla, P. Puigdomenech, M. Vaitilingom, Y. Bertheau, and J. Remacle. (2006) A microarray-based detection system for genetically modified (GM) food ingredients. Plant Mol. Biol. 61:123-139

Lipp, M., P. Brodmann, K. Pietsch, J. Pauwels, and E. Anklam. (1999) IUPAC collaborative trial study of a method to detect genetically modified soy beans and maize in dried powder. J. AOAC Int. 82:923-928

Markoulatos, P., N. Siafakas, and M. Moncany. (2002) Multiplex polymerase chain reaction: A practical approach. J. Clin. Lab. Anal. 16:47-51

Meyer, R. (1999) Development and application of DNA analytical methods for the detection of GMOs in food. Food Control 10:391-399

Miraglia, M., K.G. Berdal, C. Brera, P. Corbisier, A. Holst-Jensen, E.J. Kok, H.J.P. Marvin, H. Schimmel, J. Rentsch, J.P.P.F. van Rie, and J. Zagon. (2004) Detection and traceability of genetically modified organisms in the food production chain. Food Chem. Toxicol. 42:1157-1180 
Moreano, F., U. Busch, and K-H. Engel. (2005) Distortion of genetically modified organism quantification in processed foods: influence of particle size compositions and heat-induced DNA degradation. J. Agric. Food Chem. 53:99719979

Neogen. (2001) Neogen Corporation press release: Neogen releases easy, GIPSA verified test to detect StarLink corn. http://www.neogen.com/press gipsastarlink.htm (23 June 2006)

Orlandi, P.A., K.A. Lampel, P.K. South, S.K. Assar, L. Carter and D.D. Levy. (2002) Analysis of flour and food samples for cry9C from bioengineered corn. J. Food. Prot. 65:426-431

Perron, A., P. Raymond, and R. Simard. (2006) The occurrence of antibiotic resistance genes in Taq polymerases and a decontamination method applied to the detection of genetically modified crops. Biotechnol. Lett. 28:321-325

Quirasco, M., B. Schoel, J. Plasencia, J. Fagan, and A. Galvez. (2004) Suitability of realtime quantitative polymerase chain reaction and enzyme-linked immunosorbent assay for cry9C detection in Mexican corn tortillas: fate of DNA and protein after alkaline cooking. J. AOAC Int. 87:639-646 
Rengarajan K., S.M. Cristol, M. Mehta, and J.M. Nickeson. (2002) Quantifying DNA concentrations using fluorometry: A comparison of fluorophores. Mol. Vis. 8:416421

Ronning, S.B., M. Vaitilingom, K.G. Berdal, and A. Holst-Jensen. (2003) Event specific real-time quantitative PCR for genetically modified Bt11 maize (Zea mays). Eur. Food Res. Technol. 216:347-354

Rossen, L., P. Norskov, K. Holmstrom, and O.F. Rasmussen. (1992) Inhibition of PCR by components of food samples, microbial diagnostic assays and DNA-extraction solutions. Int. J. Food Microbiol. 17:37-45.

Sachadyn, P. and J. Kur. (1998) The construction and use of a PCR internal control. Mol. Cell. Probes 12:259-262.

Saiki, R.K., S. Scharf, F. Faloona, K.B. Mullis, G.T. Horn, H.A. Erlich, and N. Arnheim. (1985) Enzymatic amplification of $\beta$-globin genomic sequences and restriction site analysis for diagnosis of sickle cell anemia. Science. 230:1350-1354

Saiki, R.K., T.L. Bugawan, G.T. Horn, K.B. Mullis, and H.A. Erlich. (1986) Analysis of enzymatically amplified $\beta$-globin and HLA-DQ $\alpha$ DNA with allele-specific oligonucleotide probes. Nature. 324:163-166 
Saiki, R.K., D.H. Gelfand, S. Stoffel, S.J. Scharf, R. Higuchi, G.T. Horn, K.B. Mullis, and H.A. Erlich. (1988) Primer-directed enzymatic amplification of DNA with a thermostable DNA polymerase. Science. 239:487-491

Saiki, R.K., P.S. Walsh, C.H. Levenson, and H.A. Erlich. (1989) Genetic analysis of amplified DNA with immobilized sequence-specific oligonucleotide probes. Proc. Natl. Acad. Sci. USA 86:6230-6234

Sambrook, J. and D.W. Russell. (2001) Molecular Cloning: A Laboratory Manual. $3^{\text {rd }}$ edn., Cold Spring Harbour, New York: Cold Spring Harbor Laboratory Press,.

Sano, T., C.L. Smith, and C.R. Cantor. (1992) Immuno-PCR: Very sensitive antigen detection by means of specific antibody-DNA conjugates. Science. 258:120-122

Shin, I., J. Kim, C.R. Cantor, and C. Kang. (1999) Effects of saturation mutagenesis of the phage SP6 promoter on transcription activity, presented by activity logos. Proc. Natl. Acad. Sci. USA 97:3890-3895

Singer V.L., L.J. Jones, S.T. Yue, and R.P. Haugland. (1997) Characterization of PicoGreen reagent and development of a fluorescence-based solution assay for double-stranded DNA quantitation. Anal. Biochem. 249:228-238 
Stephen, O., N. Muller, S. Lehmann, T. Holzhauser, and S. Vieths. (2002) Development and validation of two dipstick type immunoassays for determination of trace amounts of peanut and hazelnut in processed foods. Eur. Food Res. Technol. $215: 431-436$

Studer E, I. Dahinden, J. Luthy, and P. Hubner. (1997) Nachweis des gentechnisch veranderten "Maximizer"-mais mittels der polymerase-kettenreaktion (PCR). Mitt. Geb. Lebensmittelunter Hyg. 88:515-524

Stump, W.T. and K.B. Hall. (1993) SP6 RNA polymerase efficiently synthesizes RNA from short double-stranded DNA templates. Nucleic Acids Res. 21:5480-5484

Teare, J.M., R. Islam, R. Flanagan, S. Gallagher, M.G. Davies, and C. Grabeau. (1997) Measurement of nucleic acid concentrations using the DyNA Quant ${ }^{\mathrm{TM}}$ and the GeneQuant ${ }^{\mathrm{TM}}$. BioTechniques 22:1170-1174

Terry, C.F. and N. Harris. (2001) Event-specific detection of RoundUp Ready soya using two different real time PCR detection chemistries. Eur. Food Res. Technol. $213: 425-431$

Trucksess, M.W. (2001) Determination of Cry9C protein in corn-based foods by enzymelinked immunosorbent assay: Interlaboratory study. J. AOAC Int. 84:1891-1901 
Tyagi, S. and F.R. Kramer. (1996) Molecular beacons: probes that fluoresce upon hybridization. Nature Biotech. 14:303-308

Vaitilingom, M., H. Pijnenburg, F. Gendre, and P. Brignon. (1999) Real-time quantitative PCR detection of genetically modified Maximizer maize and RoundUp Ready soybean in some representative foods. J. Agric. Food Chem. 47:5261-5266

Vitzthum, F., G. Geiger, H. Bisswanger, H. Brunner, and J. Bernhagen. (1999) A quantitative fluorescence-based microplate assay for the determination of doublestranded DNA using SYBR Green I and a standard ultraviolet transilluminator gel imaging system. Anal. Biochem. 276:59-64

Vollenhofer, S., K. Burg, J. Schmidt, and H. Kroath. (1999) Genetically modified organisms in food - Screening and specific detection by polymerase chain reaction. J. Agric. Food Chem. 47:5038-5043

Wilfinger W.W., K. Mackey, and P. Chomczynski. (1997) Effect of pH and ionic strength on the spectrophotometric assessment of nucleic acid purity. BioTechniques 22:474-481

Windels, P., S. Bertrand, A. Depicker, W. Moens, E. Bockstaele, and M. Loose. (2003) Qualitative and event-specific PCR real-time detection methods for StarLink maize. Eur. Food Res. Technol. 216:259-263 
Wolf, C., M. Scherzinger, A. Wurz, U. Pauli, P. Hubner, and J. Luthy. (2000) Detection of cauliflower mosaic virus by the polymerase chain reaction: testing of food components for false-positive 35S-promoter screening results. Eur. Food Res. Technol. 210:367-372

Zammatteo, N., L. Jeanmart, S. Hamels, S. Courtois, P. Louette, L. Hevesi, and J. Remacle. (2000) Comparison between different strategies of covalent attachment of DNA to glass surfaces to build DNA microarrays. Anal. Biochem. 280:143-150

Zhang. H., Kacharmina, J.E., Miyashiro, K., Greene, M.I., and Eberwine, J. (2001a) Protein quantification from complex mixtures using a proteomics methodology with single cell resolution. Proc. Natl. Acad. Sci. USA. 98:5497-5502

Zhang, L., S. Kosakovsky Pond, and B.S. Gaut. (2001b) A survey of the molecular evolutionary dynamics of twenty-five multigene families from four grass taxa. $J$. Mol. Evol. 52: 144-156 